Portland State University

PDXScholar

\title{
A Mineralogical and Geochemical Study of the Ferruginous Bauxite Deposits in Columbia County, Oregon, and Wahkiakum County, Washington
}

Ronald Laverne Jackson

Portland State University

Follow this and additional works at: https://pdxscholar.library.pdx.edu/open_access_etds

Part of the Geology Commons

Let us know how access to this document benefits you.

\section{Recommended Citation}

Jackson, Ronald Laverne, "A Mineralogical and Geochemical Study of the Ferruginous Bauxite Deposits in Columbia County, Oregon, and Wahkiakum County, Washington" (1974). Dissertations and Theses. Paper 2133.

https://doi.org/10.15760/etd.2132

This Thesis is brought to you for free and open access. It has been accepted for inclusion in Dissertations and Theses by an authorized administrator of PDXScholar. Please contact us if we can make this document more accessible: pdxscholar@pdx.edu. 
AN ABSTRACT OF THE THESIS OF Ronald LaVerne Jackson for the Master of Science in the Department of Earth Sciences presented April 8, 1974.

Title: A Mineralogical and Geochemical Study of the Ferruginous Bauxite Deposits in Columbia County, Oregor and Wankiakum County, Washington.

APPROVED BV MEMBERS OF THE THESIS COMMITTEE:

AErvin H. Beeson, Chairman

Robert 0. Van Atta

John E. Allen

David Roe

Wet chemical analysis and instrumental neutron activation analysis (INAA) were performed on a suite of samples from three residual ferruginous bauxite profiles in'the stidy area for abundances of $\mathrm{Al}_{2} \mathrm{O}_{3}$, 
$\mathrm{SiO}_{2}, \mathrm{Fe}_{2} \mathrm{O}_{3}, \mathrm{TiO}_{2}, \mathrm{Na}, \mathrm{Sc}, \mathrm{Hf}, \mathrm{Cr}, \mathrm{Co}, \mathrm{La}, \mathrm{Sm}, \mathrm{Yb}, \mathrm{Iu}$, and Th. In addition a mineralogical study accompanied this research, using petrographic, differential thermal, and $x$-ray diffraction techniques. In each profile, the relative mobility of these elements were calculated by empirical methods for comparison with the parent rock and mineral properties in the saprolite.

This study indicates that the first original constituent of the basalt to decompose under the influence of weathering is interstitial glass. The second phase results in the decomposition of plagioclase and pyroxene. Plagioclase alters mainly to kaolinite and metahalloysite. Pyroxene and basaltic glass alters mainly to nontronite, hematite, limonite, and amorphous clay. Opaques remain nearly unaltered. The low grade ferruginous bauxite ore is not derived solely from basalt, but also forms by weathering of younger sedimentary strata that overlie the basalt flows of the Columbia River Group. In general, components that are progressively depleted under the influence of weathering are $\mathrm{SiO}_{2}, \mathrm{Na}, \mathrm{La}, \mathrm{Sm}$, and $\mathrm{Lu}$; these losses result in greater concentration of $\mathrm{Al}_{2} \mathrm{O}_{3}, \mathrm{Fe}_{2} \mathrm{O}_{3}, \mathrm{TiO}_{2}, \mathrm{Sc}, \mathrm{Cr}$, Th, and Hf. Cobalt behaves erratically. There seems to be no predictable relationship between the ratios of rare earth elements in ferruginous bauxite and the parent rock. In the most weathered zone, $\mathrm{Fe}_{2} \mathrm{O}_{3}, \mathrm{TiO}_{2}, \mathrm{Al}_{2} \mathrm{O}_{3}, \mathrm{Sc}, \mathrm{Hf}, \mathrm{Cr}$, and $\mathrm{Th}$ are enriched. $\mathrm{Na}, \mathrm{SiO}_{2}, \mathrm{Sm}$, and $\mathrm{Lu}$ are depleted relative to the parent rock. Trace elements associated with iron-rich pisolites are Iu, Yb, Th, and Co. Only Th is associated with gibbsite. 
A MINERALOGICAL AND GEOCHEMICAI STUDY OF THE FERRUGINOTS BATXITE DEPOSITS IN COLUMBIA COUNTY, OREGON AND .

WAHKIAKUM COUNTY, WASHINGTON

\author{
by \\ RONAID LAVERNE JACKSON
}

A thesis submitted in partial fulfillment of the requirements for the degree of

\author{
MASTER OF SCIENCE \\ in \\ GEOLOGY \\ Portland State University \\ 1974
}


TO THE OFFICE OF GRADUATE STUDIES AND RESEARCH:

The members of the Committee approve the thesis of Ronald LaVerne Jackson presented April 8, 1974.

Mărvin H. Beeson, Chairman

Robert 0. Van Atta

John E. Allen

David Roe

APPROVED:

Richard E. Thoms, Head, Department of Earth Sciences

David T. Clark, Dean of Graduate Studies 


\section{ACKNOWLEDGEMENTS}

This study was made possible by financial support from Reynolds Metals Company and who also kindly provided wet chemical analysis on numerous samples. Grateful acknowledgement is made to Marvin H. Beeson who guided this research throughout its duration. Thanks are due to Robert 0. Van Atta, John E. Allen, and Reuben C. Newcomb for reviewing the manuscript and making hilpful suggestions for its improvement. The illustrations are by Gregory T. Both; his help is greatly appreciated. Special thanks are given to my devoted and understanding wife, Linda Jean, who prepared samples for analysis and typed the manuscript.

Several discussions with John W. Hook, Reynolds Metals Company, on the ferruginous bauxites in the study area were beneficial. Richard W. White, U. S. Geological Survey, provided pertinent references on the weathering of basaltic rocks. 
TABLE OF CONTENTS

PAGE

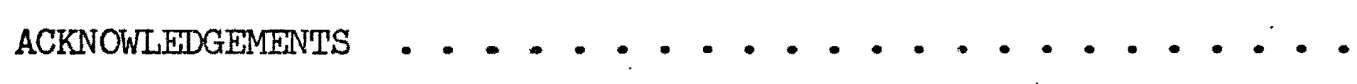

iii

IIST OF TABLES

IIST OF FIGURES . . . . . . . . . . . . . . . . . . viii

I. INTRODUCTION. . . . . . . . . . . . . . 1

Purpose and distribution. . . . . . . . . 1

Location of the study area. . . . . . . . . 1

Nature of present work. . . . . . . . . . 3

Location of ferruginous bauxite profiles. . . . . 4

Field collection. ............ 4

Definitions . . . . . . . . . . . 5

II. GEOGRAPHY . . . . . . . . . . . 7

Geography and vegetation of southwestern Washington and northwestern Oregon ......... 7

Topography................. 8

III. GEOLOGY OF THE FERRUGINOUS BAUXITE DEPOSITS . • • • • 9

Previous geologic investigations. . . . . . . 9

Geologic Setting. . . . . . . . . . 9

Field relations and nature of the ferruginous bauxite in northwestern Oregon and southwestern Washington...................

IV. METHODS OF INTESTIGATION. . . . . . . . . . 
PAGE

Mineralogical methods . . . . . . . . . .

Petrographic analysis

Differential thermal analysis

$\mathrm{X}$-ray diffraction analysis

Geochemical methods ..............

Instrumental neutron activiation analysis (INAA) wet chemical analysis

V. GENERAT DESCRIPTION . . . . . . . . . . . 20

Basaltic corestone profile......... 20

Wahkiakum County profile A. . . . . . . . 20

Wahkiakum County profile B. . . . . . . 20

VI. MINERALOGY OF THREE SELECTED FERRUGINOUS BAUXITE

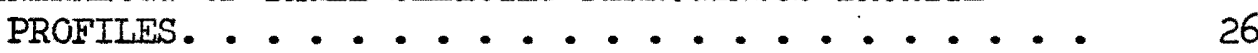

Introduction. .............. 26

Basaltic corestone profile. . . . . . . 26

Presentation of analysis

Weathered zones

Wahkiakum County profile A. . . . . . . . 45

Presentation of analysis

Weathered zones

Wahkiakum County profile B. . . . . . . 55

Presentation of analysis

Weathered zones

VII. GEOCHEMISTRY OF THREE FERRUGINOUS BAUXITE PROFIIES. • 60

Presentation of analysis. ........ 60

Methods of interpreting data......... 60 
PAGE

Relative mobility of individual elements in the three profiles. ..............

Basaltic corestone profile......... 66

Wahkiakum County profile A. . . . . . . 74

Wahkiakum County profile B. ....... 76

Trace elements in gibbsite and limonite..... 77

The relative mobility of elements in the most weathered zones from each profile...... 78

Rare earth ratios .......... 78

VIII. SUMMARY AND CONCLUSIONS . . . . . . . . . 82

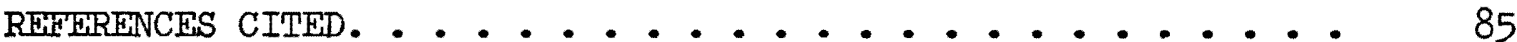




\section{LIST OF TABLES}

TABLE

PAGE

I Elemental Abundance of Standard Rocks (in ppm, unless specified) used for INAA Computer Data ....... 16

II Time Schedule for Counting Samples . . . . . . 18

III Computer Program Data. . . . . . . . . . 19

IV Identification of Minerals from Mineralogical Tests. . 33

V-a Oxides and Elemental Abundances of a Suite of Samples from Basaltic Corestone Profile........ 60

V-b Oxides and Elemental Abundances of a Suite of Samples from Wahkiakum County Profile A. . . . . . . .

V-c Oxides and Elemental Abundances of a Suite of Samples from Wahkiakum County Profile B. . . . . . . .

V-d Elemental Abundances of Columbia River Basalt Collected in Wahkiakum County, Washington. ......

VI-a Basaltic Corestone Profile--Concentration Ratios . . : 67

VI-b Wahkiakum County Profile A--Concentration Ratios . . 68

VI-c Wahkiakum County Profile B--Concentration Ratios . . . 69

VII Rare Earth Ratios. ............ 80

VIII Elements Enriched or Depleted in the most Weathered Zone from each Profile............. 


\section{LIST OF FIGURES}

\section{FIGURE}

PAGE

1 General location of ferruginous bauxite deposits in western Cregon and southwestern Washington .....

2 Generalized geologic map of St. Helens area, Oregon and Kelso-Cathlamet area, Washington .......

3 Generalized correlation chart of the Kelso-Cathlamet area, Washington and St. Helens, Oregon...... 10

4 Summary log of basaltic corestone profile. . . . . 21

5 Sectional view of basaltic corestone . . . . . 22

6 Summary log of Wahkiakum County profile A . . . . 23

7 Summary log of Wahkiakum County profile B . . . 25

8 Differential thermal curves of a suite of samples from the basaltic corestone profile. . . . . . .

9 Differential thermal curves of a suite of samples from Wahkiakum County profile A. . . . . . . 28

10 Differential thermal curves of a suite of samples from Wahkiakum County profile B. . . . . . . .

$11 \mathrm{X}$-ray diffractograms of a suite of samples from the basaltic corestone profile ...........

12 X-ray diffractograms of a suite of samples from Wahkiakum County profile A . . . . . . . .

13 X-ray diffractograms of a suite of samples from Wahkiakum County profile B ............

14 Plot of percentage of original constituents remaining versus the relative degree of weathering in the basaltic corestone profile. . . . . . . .

15 Photomicrograph, plane polarized light, showing unaltered basalt. Basaltic corestone profile. . . 
16 Photomicrograph, cross polarizers, showing slightly weathered zone. Basaltic corestone profile.....

17 Photomicrograph, cross polarizers, showing moderately weathered zone. Basaltic corestone profile...................

18 Photomicrograph, cross polarizers, showing highly weathered zone. Basaltic corestone profile.....

19 Photomicrograph, cross polarizers, showing ferruginous bauxite zone. Basaltic corestone profile.

20 Photomicrograph, cross polarizers, showing moderately weathered zone. Wahkiakum County profile A. . . . . . . . . . . . . .

21 Photomicrograph, cross polarizers, showing highly weathered zone. Wahkiakum County profile A. ...

22- Photomicrographs, plane polarized light, showing pisolitic material characteristic of ferruginous bauxite ore zone. Wahkiakum County profile A....

23 Photomicrographs, cross polarizers, showing the amorphous nature of the ferruginous bauxite zone. Wahkiakum County profile B............

24 Plot of concentration ratios. Basaltic corestone profile......................

25 Plot of concentration ratios. Wahkiakum County profile A. . . . . . . . . . . . . . . 


\section{INTRODUCTION}

\section{PURPOSE}

Field studies, geochemistry, and mineralogy have been employed to study bauxitic soils. This study is based on trace element analysis, a geochemical approach which has not been widely employed in the study of intensively weathered rocks.

The purpose of this investigation is to examine the geochemistry and mineralogy of a residual bauxitic soil in order to determine and understand the relative mobility of major oxides and trace elements during the formation of bauxite from parent rock.

\section{LOCATION OF THE STUDY AREAS}

The ferruginous bauxite areas in southwestern Washington and northwestern Oregon were selected because: (1) the geology of the ferruginous bauxite deposits and underlying rocks has been described in published reports, (2) the ferruginous bauxites are considered to be a residual soil formed from basalt, (3) little work has been done on the trace element analysis of the ferruginous bauxites, and (4) the deposits are located relatively close to Portland State University.

The locations of the major ferruginous bauxite deposits of the Pacific Northwest are principally in Marion, Washington, Columbia, and Multnomah Counties in Oregon, and Cowlitz and Wahkiakum Counties in Washington (Figure 1). Minor deposits have also been reported in Clackamas County, Oregon. 


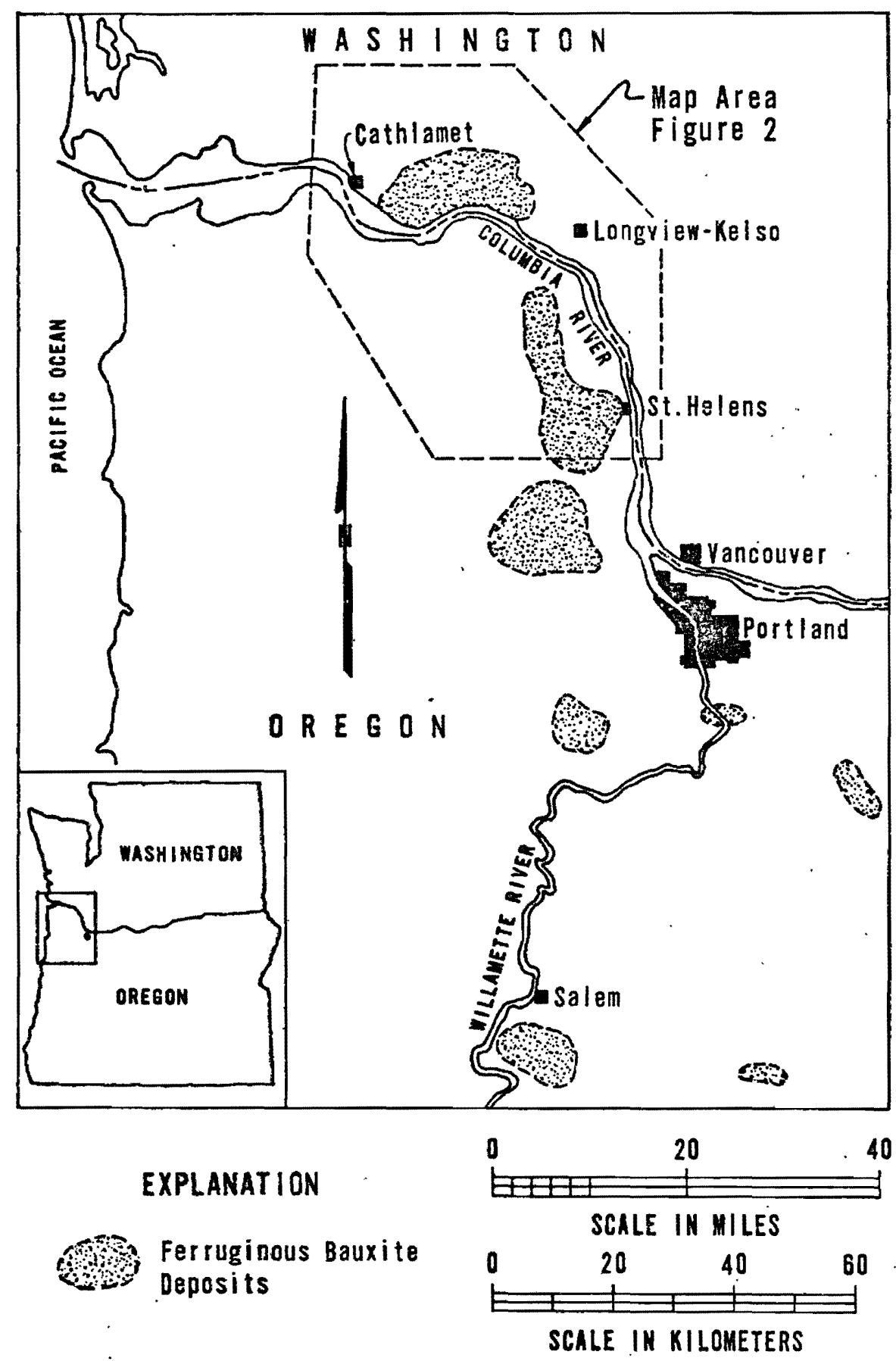

Figure 1. General location of ferruginous bauxite deposits in western Oregon and southwestern Washington (modified after Livingston, 1966). 
The deposits lie within the central and northern portions of the Willamette Valley physiographic province and eastern extensions of the Coast Range Province in Oregon (Dicken, 1965). In the Willamette Valley, the known deposits are generally restricted to the TualatinPortland West Hills, Chehalem Mountains, and Salem-Eola Hills to the south. In southwestern Washington, the bauxitic soils lie within the southeastern flanks of the Willapa Hills (subdivision of the Coast Range Province).

\section{NATURE OF PRESENT WORK}

Field studies were carried out from July to November, 1970. The ferruginous bauxite deposits and Tertiary rocks were examined at roadcuts and natural exposures. During the summer of 1970, the author was employed by Reynolds Metals Company to participate in a bulk sampling program of the ferruginous bauxite ore in Oregon and Washington. Several pits, most deeper than 20 feet $(6.1 \mathrm{~m})$, were examined and mapped in detail. The ore profiles of two test pits in Columbia County, Oregon have been described by the author (Jackson, 1971).

Laboratory tests performed on selected samples include instrumental neutron activation analysis (INAA), wet chemical analysis, differential thermal analysis, $x$-ray diffraction analysis, and petrographic analysis. These techniques are described under "Methods of Investigation." Data was collected from January 1971 through June 1972. Along with field and laboratory studies, a survey of the literature related to ferruginous bauxite was conducted. 
LOCATION OF FERRUGINOUS BAUXITE PROEILES

Due to thick vegetation cover and thick soil mantle, there are few lateritic exposures from which to collect samples. For two profiles a truck-mounted cable tool drill rig was utilized to obtain samples. These borings, nearly one mile $(1.6 \mathrm{~km})$ apart, were drilled along the Cathlamet Road in the southeastern portion of Wahkiakum County, Washington in $5 W / 4$ sec. 6 T. 8 N. R. 4 W. and SE3/4 sec. 1 T. 8 N. R. 5 W. (Cathlamet 15-minute Quadrangle), and have been designated as Wahkiakum County profile A and Wahkiakum County profile B, respectively (Figure 2). Both borings are located atop a well-rounded ridge which ranges in elevation from 250 feet $(76 \mathrm{~m})$ to 1000 feet $(305 \mathrm{~m})$. Wahkiakum County profile A and Wahkiakum County profile B are at elevations of 825 feet (252 m) and 845 feet $(258 \mathrm{~m}$ ) (sea level datum), respectively.

The third profile is from a weathered basaltic corestone which was taken at 21 feet $(6.4 \mathrm{~m})$ below ground level in a test pit ${ }^{I}$ in Columbia County, Oregon (elevation 720 feet $(220 \mathrm{~m}), N W / 4 \mathrm{NW} / 4 \mathrm{sec} .23$ T.5 N. R.2 W. St: Helens 15-minute Quadrangle) nearly 4.5 miles (7.2 Km) northwest of St. Helens, Oregon (Figure 2).

\section{FIEID COLTECTION}

Wahkiakum County profile A and Wahkiakum County profile B are borings to depths of 55 feet $(16.8 \mathrm{~m})$ and 165 feet $(50.3 \mathrm{~m})$, respectively. The drilling was accomplished with a truck-mounted cable tool

${ }^{1}$ Pits were excavated by Reynolds Metals Company. After excavation of the ferruginous bauxite ore, pits were refilled and recontoured to original grade. 


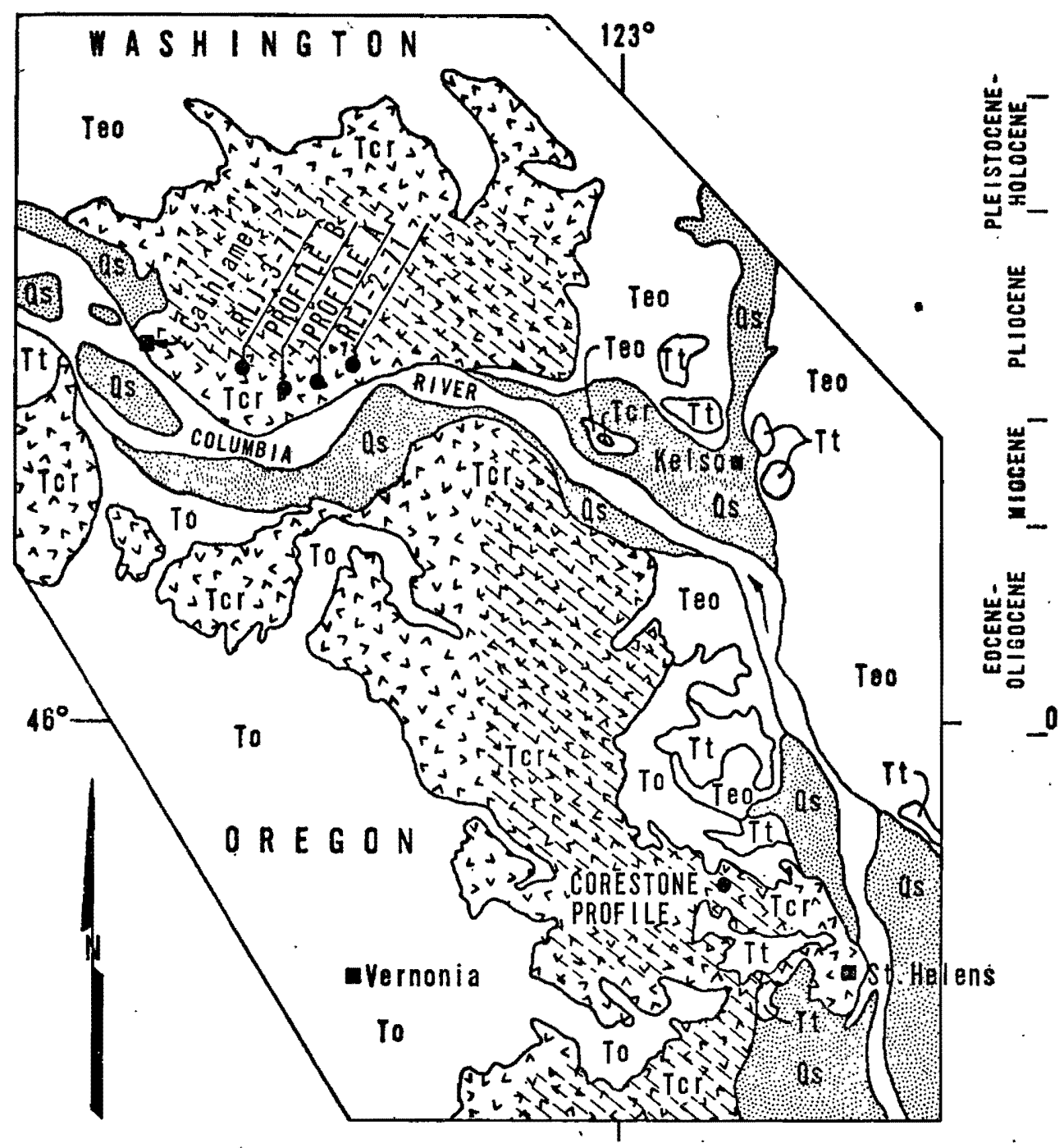

EXPLANATION

SEDIMENTARY AND EXTRUSIVE IGNEOUS ROCKS

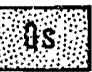

Unconsolidated Sediments

is

Post-Troutdale silty Clay (Omitted)

$\mathrm{Tt}$

Troutdale Formation

TCr $T^{2}$

Columbia River Group

To

Oligocene Sedimentary Rocks

Teo

Older Eocene-oligocene Rocks, undifferentiated

EIIN

Ferruginous Bauxite Deposits (Approximate)

Profile and Sample Locations

SCALE IN MILES

Figure 2. Generalized geologic map of St. Helens area, Oregon and Kelso-Cathlamet area, Washington. General location of ferruginous bauxite deposits after Wilkinson, et al. (1946) and Livingston (1966). Map modified from Huntting (1961) and Peck (1961). 
drill rig mounted with a 4 -inch $(10.2 \mathrm{~cm})$ I.D. hollow stem barrel. Samples were taken continuously from the surface to the bottom. In most cases, a two foot $(0.6 \mathrm{~m})$ sample was split for wet chemical analysis and other laboratory tests.

Several grab samples were collected from an exfoliated basaltic corestone. In addition two basalt sample were collected for trace element analysis. Sample RLJ-3-71 was obtained from a small roadcut in Wahkiakum County, Washington $\mathrm{SE} / 4 \mathrm{sec} .3 \mathrm{~T} .8$ N. R.5 W. (Figure 2). Sample RLJ-2-7I was collected at a small rock quarry ( $\mathrm{NE}^{1 / 4}$ sec. 7 T. 8 N. R. 4 W. ) approximately 3.5 miles $(5.6 \mathrm{~km})$ due west of sample RLJ-3-7I along Cathlamet Road (Figure 2).

\section{DEFINITIONS}

Libbey and other (1945) defined 'ferruginous bauxite' as a Iateritic deposit confined to the Miocene basalt in northwestern Oregon. Their study showed that bauxite minerals were common and, in general, the alumina content was higher than the iron oxide content. In this report, ferruginous bauxite refers to a laterite formed from weathering processes in which the weathered residual contains a relatively high alumina and iron oxide concentration and a low silica content. The name ore is arbitrarily defined as a ferruginous bauxite that has no more than 10 percent non-reactive silica and no less than 30 percent alumina. A corestone is spherical to elliptical shaped rock that was formed from basalt by weathering processes. 


\section{GEOGRAPHY}

\section{CLIMATE AND VEGETATION OF SOUPHWESTERN WASHINGTON AND NORTHWESTERN OREGON}

The maritime climate in western Washington and Oregon is characterized by: mild temperatures and long periods of cloudiness; moist and mild winter months; warm and nearly dry summer months; a long frostfree season; and rainfall mostly between October $I$ and March 31 (Franklin and Dryness, 1969, p. 31).

In the Cathlamet-Kelso area and St. Helens area, mean annual precipitation ranges from 40-100 inches (102-254 cm). The January mean minimum temperature is nearly $0^{\circ}$ centigrade. The July mean maximum temperature is approximately $27^{\circ}$ centigrade. Meteorological data was estimated from published charts in "Vegetation of Oregon and Washington" (Franklin and Dryness, 1969, p. 33-35).

The vegetation (Livingston, 1966) in the study area consists largely of many varieties of conifers. Most notably among the coniferous trees are Douglas fir (Pseudotsuga menziesii), western hemlock (Tsuga heterophylla), and western red cedar (Thuja plicata). Common decidious trees are willows (Salix sp.), big-leaf maple (Acer macrophyllum), Pacific dogwood (Cornus nuttallii), cascara (Rhamnus purshiana), and red alder (Alnus rubrä). Common shrubs include Pacific poison oak (Rhus diversiloba), devils club (Ophopanax horridum), Oregon grape (Berberis nervosa) blue elderberry (Sambucus cerulea), salal (Gaultheria shallon), 
and blackberry (Rubus sp.). Herbaceous species, red willowweed (Epilobium latifolium), a common thistle (Arsium vulgare), and bracken fern (Pteridium aquilinium) dominate burned and logged areas, and abandoned fields.

\section{TOPOGRAPHY}

In the ferruginous bauxite areas of northwestern Oregon and southwestern Washington, the topography reflects an eroded upland surface that has developed on the Columbia River basalt of Miocene age (Iibbey and others, 1945; and Livingston, 1966). The Columbia River, the master stream in the Pacific Northwest, dissects this area. Tributaries to the Columbia River are v-shaped in cross-section. Their longitudinal gradients are usually steep near their headwaters and gentle near their confluence with the Columbia River. Ridge divides are commonly broad and well-rounded. Cliffs and steep-sided slopes are particularly numerous along the Columbia River where Tertiary volcanic rocks crop out. Maximum relief in both areas is approximately 1500 feet $(427 \mathrm{~m})$ with an average elevation of 700 feet $(213 \mathrm{~m})$. The lowest elevation occurs along the Columbia River which is near sea level. 
III. GEOLOGY OF THE FERRUGINOUS BAUXITE DEPOSITS

PREVIOUS GEOLOGIC INVESTIGATIONS

The only detailed published report on the geology of the ferruginous bauxite deposits in the Kelso-Cathlamet area was done by L= vingston (1966). The report contains a geologic map $(1: 62,500)$ that shows the rock units and favorable bauxite localities.

Geologic reconnaissance in northwestern Oregon was carried out by Warren and others (1945). The report by Lowry and Baldwin (1952) discusses the Cenozoic geology of the lower Columbia River Valley. Geologic mapping by Wilkinson and others (1946) defines the general occurrences of the bauxite deposits and their relationship to the bedrock geology. Geologic studies related to the bauxite deposits are found in reports by Libbey and others (1945, 1946), Allen (1948), and Jackson (1971).

Corcoran and Libbey (1956) have described the deposits in the Salem Hills near Salem, Oregon.

\section{GEOLOGIC SETTING}

A generalized geologic map and a correlation chart of the rock units are shown in Figure 2 and Figure 3. The rocks exposed in the St. Helens and Kelso-Cathlamet area range from Eocene to Holocene age. The early Tertiary rocks are chiefly a complex interfingering sequence of volcanic-rich marine sedimentary and extrusive volcanic rocks. 


Unconsolidated Sedimentary rocks (Alluvium, silt, terrace deposits and Iandslides)

Figure 3. Generalized correlation chart of the Kelso-Cathlamet area, Washington and St. Helens area, Oregon. Modified after Livingston (1966) and Wilkinson and others (1946). Dot pattern indicates rock units which have been bauxitized. 
These rocks have been named the Cowlitz Formation (Eocene), Goble volcanics (Eocene-Oligocene), and Oligocene sediments. Unconformably overlying much of the Eocere-Oligocene unit are basalt flows of the Columbia River Group of Miocene age and minor amounts of intercalated marine and non-marine sedimentary rocks. The basalt flows are grayblack to black, dense, and fine-grained. Jointing is typically columnar and blocky. The thickness of most flows is 30 feet $(9.1 \mathrm{~m})$, although some vary up to 50 feet $(15.2 \mathrm{~m})$. Subsequent to the last basalt outpourings, the upper flows were subjected to an intense pericd of weathering during which the bauxite formed from the basalt.

Overlying the ferruginous bauxite is a silt to silty clay unit that ranges in thickness from 10 to 40 feet $(3-12.2 \mathrm{~m})$. Typically, the upper portion is stiff and light brown silt to clayey silt; whereas the lower portion is a stiff to very stiff, mottled red and light brown silty clay. Scattered well-rounded chert pebbles and cobbles have been observed by the author in the mottled red silty clay.

Scattered poorly consolidated conglomerate beds with interbeds of sandstione and claystone are perched on the walls of the Columbia River Valley This assemblage is known as the Troutdale Formation of Pliocene age.

Unconsolidated gravels and sands (terrace deposits and alluvium) were deposited during Pleistocene time.

\section{FIELD RELATIONS AND NATURE OF THE FERRUGINOUS BAUXITE DEPOSITS IN NORTHWESTERN OREGON AND SOUTHWESTERN WASHINGTON}


ization of the upper Columbia River basalt flows. Their outline is principally governed by topographic controls. The deposits occur as blanket-shaped bodies along the tops of well-rounded ridges and hills ranging in elevation from 200 to 2000 feet $(61-610 \mathrm{~m})$. On the basis of several borings, the deposits in the Kelso-Cathlamet area appear to be thickest where the drainage is well developed (John W. Hook, 1971). The residual weathered rock ranges in thickness from several feet to an estimated 200 feet $(61 \mathrm{~m})$.

The ferruginous bauxites are adequately described in several published reports. Information from published studies and field investigations conducted by this writer will be summarized here. The overlying silty clay unit is omitted in this discussion. The characteristics of the bauxite deposits in the St. Helens and KelsoCathlamet area are very similar. Where a complete residual soil profile exists; the upper 10 to 20 feet $(3-6.1 \mathrm{~m})$ usually contains three distinct textural layers (Jackson, 1971). The uppermost layer contains abundant red-brown pisolites in a gibbsite-rich matrix. The intermediate zone consists of unevenly distributed gibbsite-rich and limonite nodules in an orange-brown to brown earthy bauxite matrix. The lowest layer is characterized by its brown color and earthy fine-grained texture.

Chemically these three soil layers usually have a low $\mathrm{SiO}_{2}$ content (less than 10 percent) and relatively high $\mathrm{Al}_{2} \mathrm{O}_{3}$ and $\mathrm{Fe}_{2} \mathrm{O}_{3}$ contents ( $31 \pm$ and $33 \pm$ percent, respectively) (Jackson, 1971). The contents of these three horizons all satisfy the definitions of ferruginous bauxite ore. 
Several workers (Livingston, 1966 and others) have noted that the silica content is commonly higher than 10 percent in the pisolitic zone. Chemical and petrographic studies show that the silica is partly in the crystalline form (Allen, 1948; Livingston, .1966).

Underlying the ore horizon is a stiff, varicolored clay zone with a silica content often greater than 15 percent. This material is characterized by its relict salt and pepper texture and spheroidal weathering pattern with associated fractures, and joints. Commonly distributed throughout the ferruginous bauxite are basaltic corestones which become prevalent with depth. The laterite transitionally changes at depth to unaltered basalt. 


\section{METHODS OF INVESTIGATION}

\section{MINERALOGICAL METHODS}

Petrographic Analysis

Although the altered material was too fine grained for an adequate study by this method, the polarizing microscope was useful for observing textural characteristics, mineral alterations, and non-clay minerals. Prior to mounting, most specimens were impregnated with a plastic resin that has a refractive index of about 1.54 .

Differential Thermal Analysis

The apparatus used for differential thermal anaIysis was providèd by the Department of Geology and Mineral Industries at their laboratory in Portland, Oregon. Most specimens analyzed represent a composite of a two foot interval $(0.6 \mathrm{~m})$. The air-dried material was mechanically split and ground by hand (mortar and pestle) to minus 100 mesh (Tyler screen). Each specimen, which weighed approximately 0.3-0.4 grams, was carefully packed into a cylindrical-shaped thermocouple and heated from room temperature to $1000^{\circ}$ centigrade at a standard rate. The sensitivity of the Heath Serva Chart recorder was varied from $1 \mathrm{mv}$ (millivolt) to $50 \mathrm{mv}$, depending on the mineral content.

$\mathrm{X}$-ray Diffraction Analysis

- Bulk samples were air-dried and hand ground to pass a U. S. 
Standard 325 mesh screen. The mounting procedures used here.were introduced to the writer by Nelson S. Higgs (personal communications, 1971). Diffractograms of the fine fraction were obtained from unoriented and oriented mounts using $\mathrm{Ni}$-filtered $\mathrm{Cu} \mathrm{K}_{\propto}$ radiation. Unoriented mounts were prepared by carefully packing the dry fine fraction into a slotted plastic mount. Oriented mounts were prepared by mixing the fine fraction with distilled water in a watch glass and the slurry was carefully siphoned onto a porous tile. Prior to analysis of the laterite samples, several dry runs were performed on a kaolinite standard in order to obtain reproducible and reliable results.

GEOCHEMICAL METHODS

Instrumental Neutron Activiation Analysis (INAA)

Instrumental neutron activation analysis was used to determine the concentration of 10 elements in selected samples. Elements that were studied include: sodium, scandium, hafnium, chromium, cobalt, lanthanum, samarium, ytterbium, lutetium and thorium.

The samples were prepared and irradiated in a similar manner as discussed by Gordon and others (1968). Two U.S.G.S. standard rocks, BCR-1 (basalt) and 0-16 (rhyolite obsidian from southeastern Oregon), and a chromium monitor were used as standards. Elemental abundances of these standards are listed in Table $I$.

Bulk samples, for the most part, were powdered and approximately one gram of each was placed in a 2-dram polyethylene vial and sealed. The sample vials and monitors were set on a rotary "lazy susan" and 


\section{TABLE I}

ELEMENTPAL ABUNDANCES OF STANDARD ROCKS (IN PPM, UNLESS SPECIFIED) USED FOR INAA COMPUTER DATA

(AFTER GORDON ET AL., 1968)

\begin{tabular}{|c|c|c|c|}
\hline ELEMENT & $\underline{B C R-1}$ & $0-16$ & $\begin{array}{c}\text { PREPARED } \\
\text { CONCENTRATION }\end{array}$ \\
\hline $\mathrm{Na} \%$ & $2.40 \pm 0.05$ & & \\
\hline Sc & $32.5 \pm 0.5$ & & \\
\hline Hf & & $8.6 \pm 0.8$ & \\
\hline $\mathrm{Cr}$ & & & 1000.0 \\
\hline Co & $36.3 \pm 0.7$ & & \\
\hline Ia & & $35 \pm 3$ & \\
\hline $\mathrm{Sm}$ & $5.9 \pm 0.5$ & & . \\
\hline $\mathrm{Yb}$ & & $5.2 \pm 0.4$ & \\
\hline · & & $0.65 \pm 0.15$ & \\
\hline Th (via $\mathrm{Pa}$ ) & & $6.7 \pm 0.3$ & \\
\hline
\end{tabular}


irradiated for one hour at a flux of about $2 \times 10^{12} \mathrm{n} / \mathrm{cm}^{-2} \mathrm{sec}$ in a General Atomic TRIGA Mark I reactor at Reed College in Portland, Oregon. After irradiation, the samples were transferred and weighed into clean vials. A high resolution lithium-drifted germanium detector and 4096channel kicksort pulse-height analyzer were used to count radioisotopes. Optimum time for counting species are listed in Table II. In order to minimize computation of elemental abundances a computer program, provided by Dr. Marvin Beeson, was utilized (Table III). Where applicable, more than one gamma ray energy peak of a radioisotope of interest was determined.

Wet Chemical Analysis

Accompanying the neutron activation analysis, lateritic samples were analyzed at Reynolds Metals Company in Longview, Washington for $\mathrm{SiO}_{2}, \mathrm{Al}_{2} \mathrm{O}_{3}, \mathrm{Fe}_{2} \mathrm{O}_{3}$, and $\mathrm{TiO}_{2} \cdot$ Determination of oxides contents were by wet chemical analysis. In addition, non-reactive silica was determined for some samples. 


\section{TABLE II}

TIME SCHEDULE FOR COUNTING SAMPLES

Long irradiation ( 1 hour at about $2 \times 10^{12} \mathrm{n} \mathrm{cm}^{-2} \mathrm{sec}^{-1}$ )

EILEMNT

$\mathrm{Sm}, \mathrm{Iu}, \mathrm{Ia}, \mathrm{Yb}$

Hf, Cr, Co, Sc, Th (via Pa)

$\mathrm{Na}$
ANALYZER

CALIBRATION

$.3 \mathrm{Kev} / \mathrm{ch}$

$12 \mathrm{Kev} / \mathrm{ch}$

$12 \mathrm{Kev} / \mathrm{ch}$
BEST TIME AFTER IRRAD. FOR COUNIING

$6-12$ days

$30-60$ days

1-3 days

Note: Time schedule for counting samples from Beeson, 1969 
TABLE III

COMPUTER PROGRAM DATA

\begin{tabular}{|c|c|c|c|c|c|}
\hline ISOTOPE & MASS NO. & ENERGY (KEV) & $\begin{array}{l}\text { NO. OF CHANNEIS } \\
\text { IN PEAK } \\
\end{array}$ & WINGS & HALF-LIFE \\
\hline $\mathrm{NaA}$ & 24 & 1368 & 22 & 6 & $0.62375 \alpha$ \\
\hline $\mathrm{NaB}$ & 24 & 1732 & 15 & 6 & $0.62375 d$ \\
\hline $\mathrm{Cr}$ & 51 & 320 & 6 & 4 & $27.8 d$ \\
\hline $\mathrm{ScA}$ & 46 & 889 & 17 & 6 & $83.9 d$ \\
\hline $\mathrm{ScB}$ & 46 & 1120 & 14 & 6 & $83.9 \mathrm{~d}$ \\
\hline CoA & 60 & 1173 & 12 & 6 & $1913.93 \mathrm{~d}$ \\
\hline $\mathrm{COB}$ & 60 & 1332 & 12 & 6 & $1913.93 d$ \\
\hline LaA & 140 & 816 & 10 & 6 & $1.676 \mathrm{~d}$ \\
\hline $\mathrm{Yb}$ & 174 & 396 & 6 & 2 & $32 \tilde{\alpha}$ \\
\hline Iu. & 177 & 208 & 8 & 4 & $6.75 d$ \\
\hline $\mathrm{Hf}$ & 180 & 482 & 8 & 6 & $44.6 \mathrm{~d}$ \\
\hline Th & 233 & 312 & 9 & 2 & $27.4 d$ \\
\hline
\end{tabular}




\section{GENERAL DESCRIPTION}

\section{BASALTIC CORESTONE PROFIIE}

A detailed description of the basaltic corestone profile is presented in Figure 4. This profile illustrates the decomposition of basalt within a short distance of the unaltered rock. The corestone was found about 21 feet $(6.4 \mathrm{~m})$ below ground level and embedded in the ferruginous bauxite. The corestone is roughly spherical in shape, about 6 inches $(15.2 \mathrm{~cm}$ ) in diameter, and composed of hard dark. gray basalt with siderite filled vesicles (Figure 5). Several exfoliated and weathered rinds enclose the coreștone. Most rinds are less than 0.1 foot $(3 \mathrm{~cm})$ in width and bound by concentric joints. Grab samples were selected for laboratory analysis.

WAHKIAKUM COUNTY PROFILE A

A massive brown clayey silt grading downward to a red silty clay extends to a depth of 18 feet $(5.5 \mathrm{~m})$. The ferruginous bauxite zone extends from 18 to 55 feet $(5.5-16.8 \mathrm{~m})$ and between depths of 53 and 55 feet (16.2-16.8 m) basaltic corestones are embedded in the laterite. A description of profile $A$ is shown in Figure 6.

\section{WAHKIAKUM COUNTY PROFILE B}

Unlike profile A, the bauxite ore zone and unaltered rock were not penetrated in this profile. The silt and clay mantle that overlies 


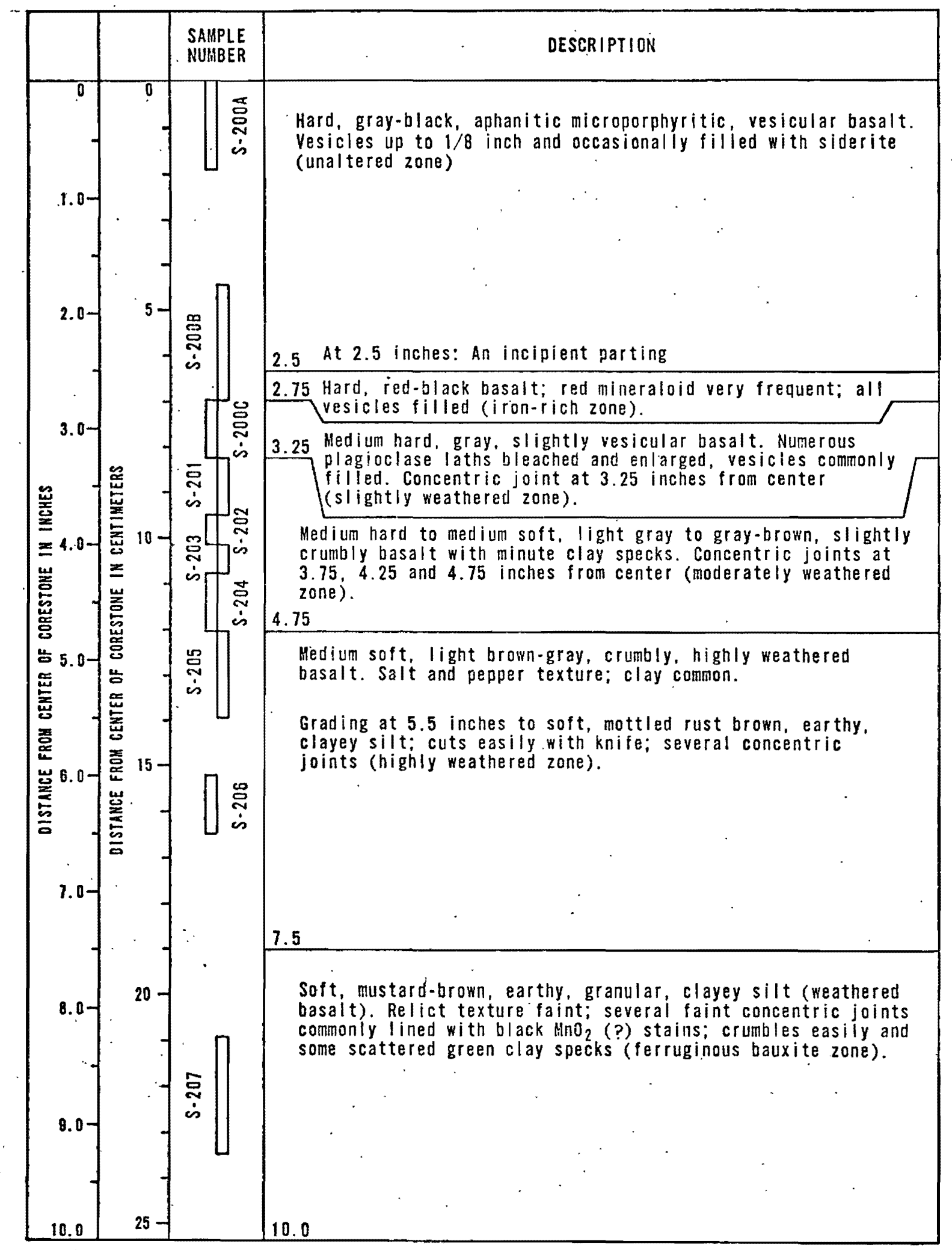

Figure 4. Summary log of basaltic corestone profile. 


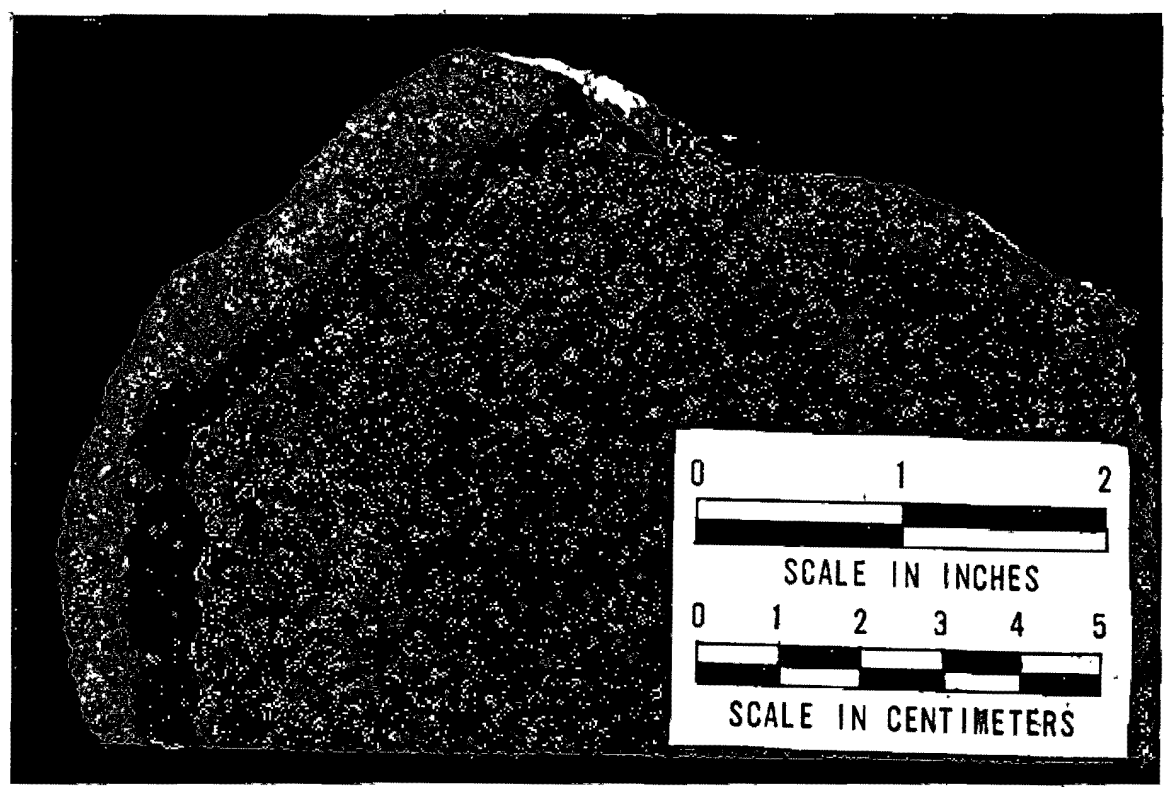

Figure 5. Sectional view of basaltic corestone. 


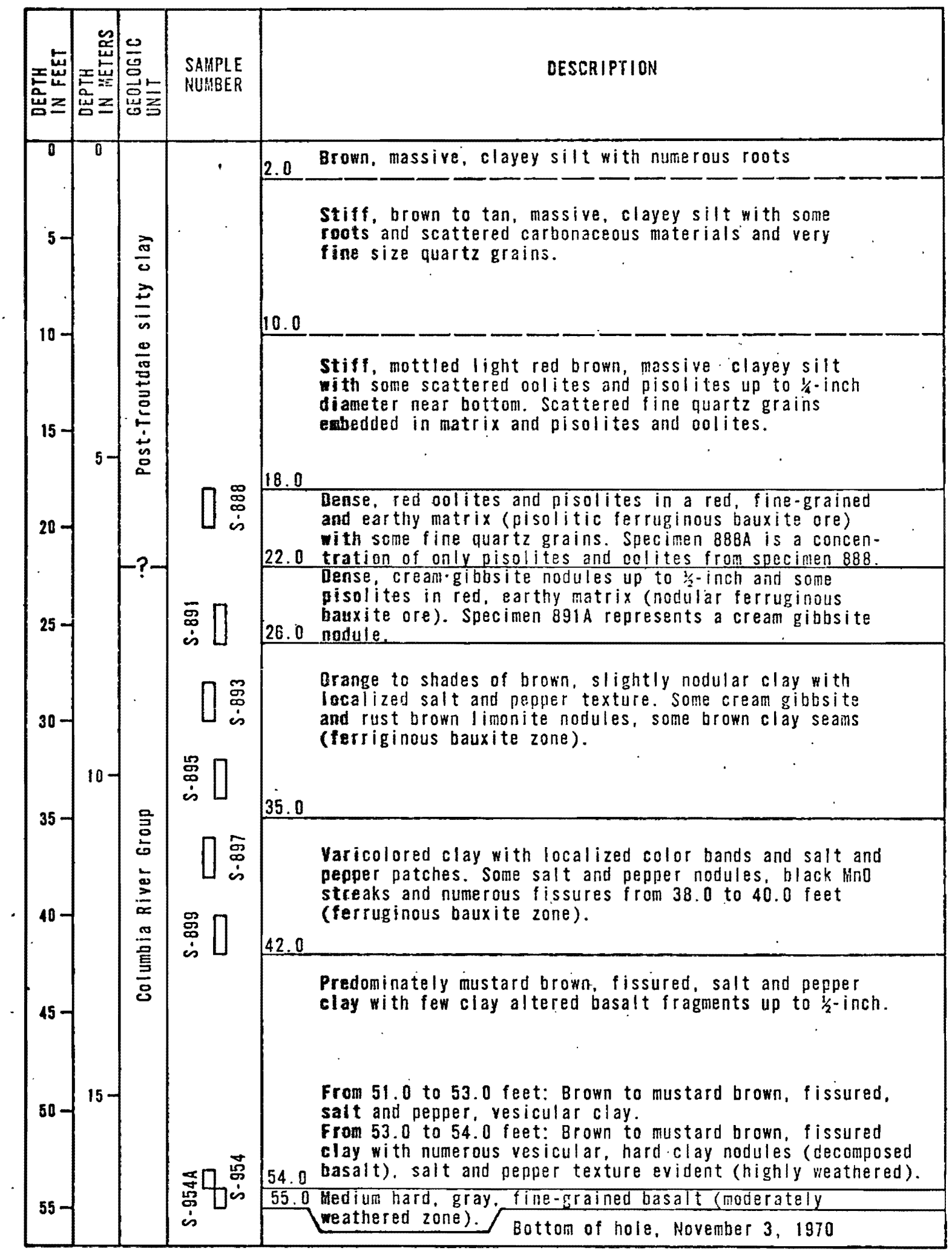

Figure 6. Summary log of Wahkiakum County profile A. 
the laterite extends, from ground level to 17 feet $(5.2 \mathrm{~m})$. From this depth to 165 feet $(50.3 \mathrm{~m})$ the material consists of laterized basalt with minor amounts of intercalated sedimentary rocks (highly decomposed). A descriptive log of profile B is given in Figure 7. 


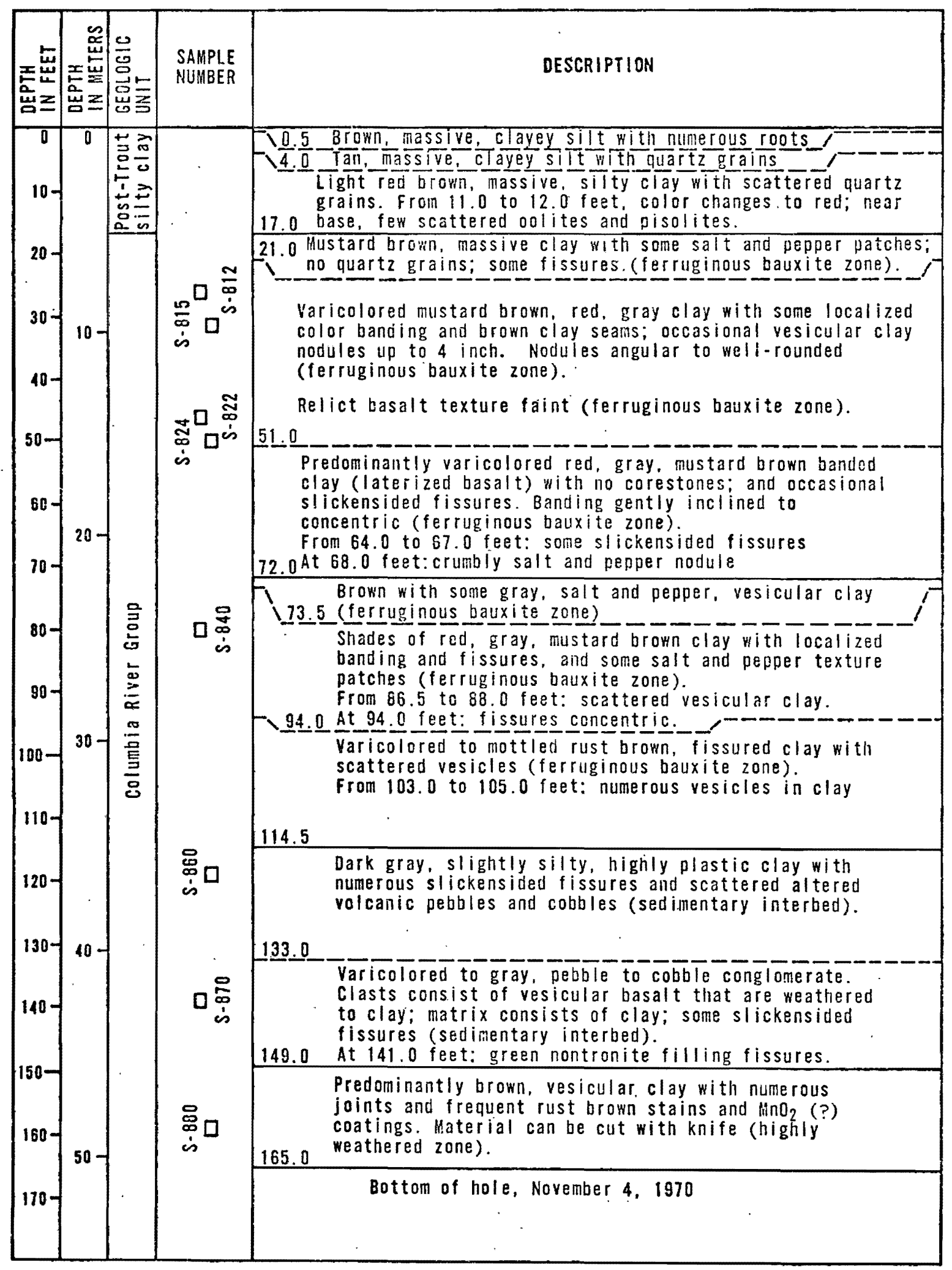

Figure 7. Summary log of Wahkiakum County profile B. 
VI. MINERALOGY OF THREE SEIECTED FERRUGINOUS BAUXITE PROFILES

INTRODUCTION

A petrographic, $x$-ray diffraction, and differential thermal analysis (DTA) was made on a suite of specimens in three ferruginous bauxite sections for purposes of correlating mineralogical and geochemical changes. A total of ten samples were examined in the basaltic corestone profile (Figure 4); and ten and eight samples were examined in profiles A and B (Figure 6 and Figure 7), respectively. The results of these tests are presented in Figure 8 through Figure 13. A summary of minerals identified from each of the mineralogical tests are listed in Table IV.

\section{BASALTIC CORESTONE PROFILE}

Presentation of Analysis

Original constituents in unaltered rock. Five original constituents were positively identified using petrographic and $x$-ray analysis: plagioclase, pyroxene, iron-rich glass, magnetite, and ilmenite. Magnetite and ilmenite were difficult to distinguish from each other under the microscope, but both were distinguished in $x$-ray diffractograms. Pyroxene, augite and pigeonite, were observed microscopically and from $x$-ray diffractograms. Olivine was not positively identified. 


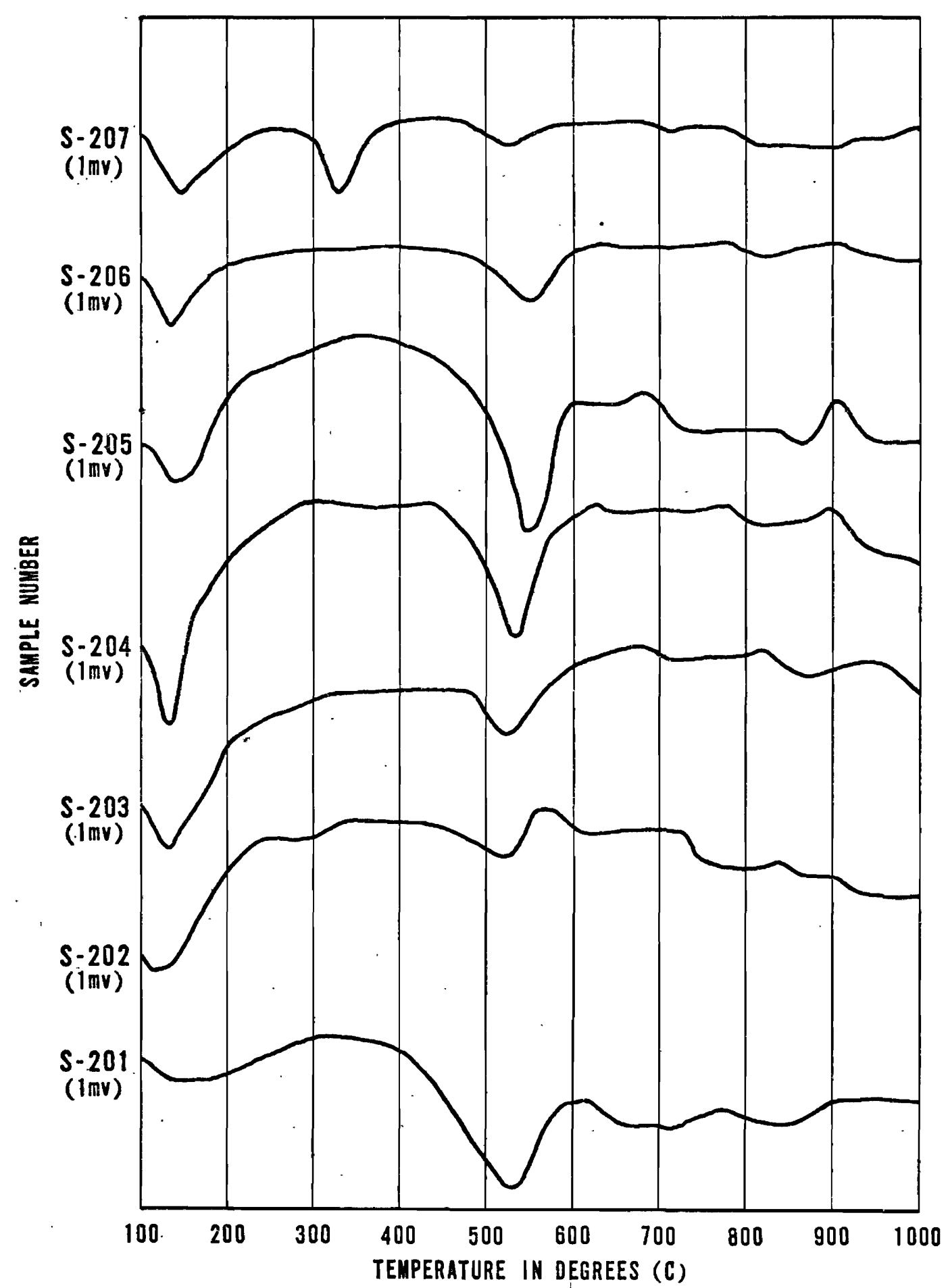

Figure 8. Differential thermal curves of a suite of samples from the basaltic corestone profile. See text for discussion. 


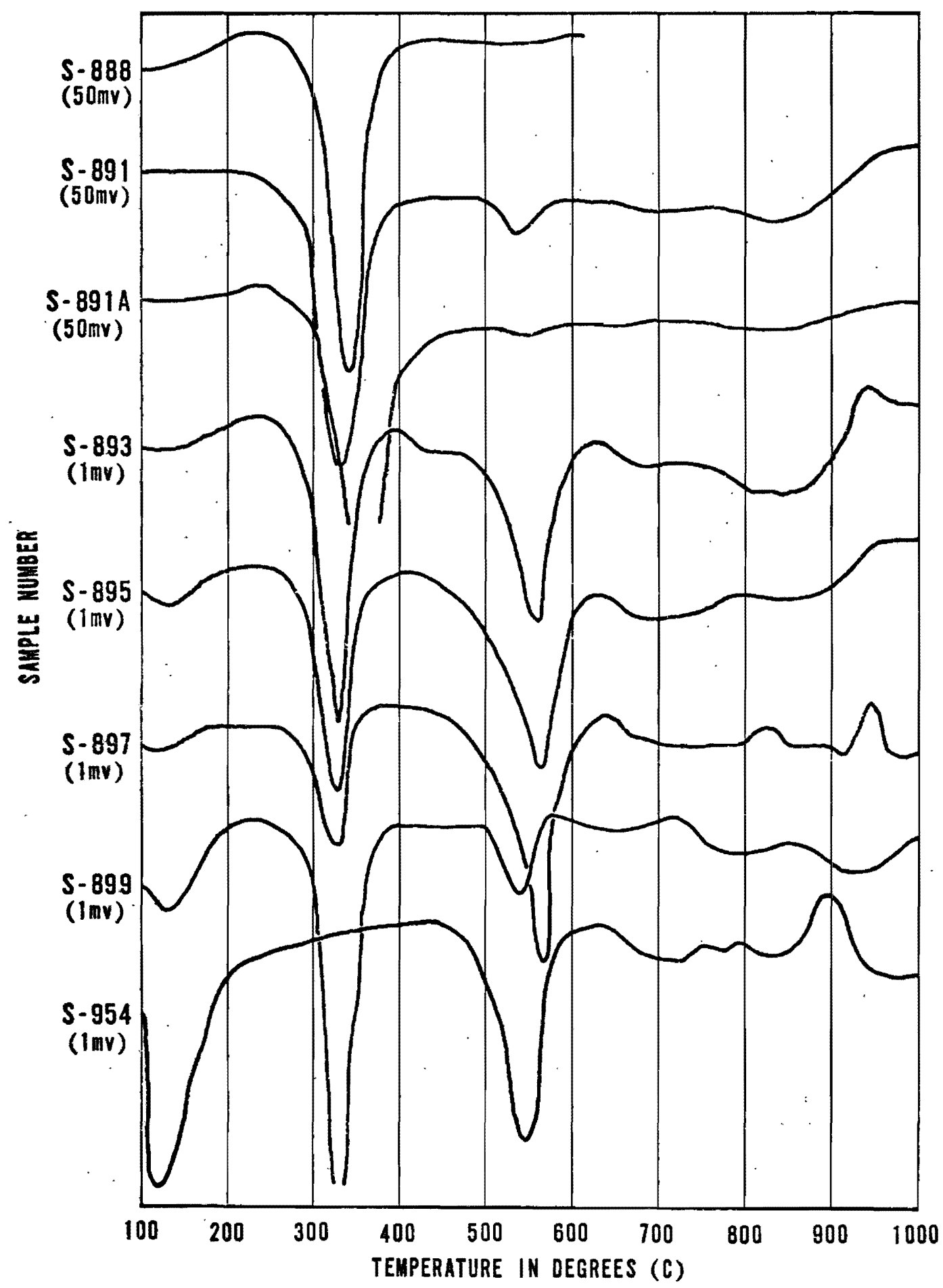

Figure 9 . Differential thermal curves of a suite of samples from Wahkiakum County profile A. See text for discussion. 


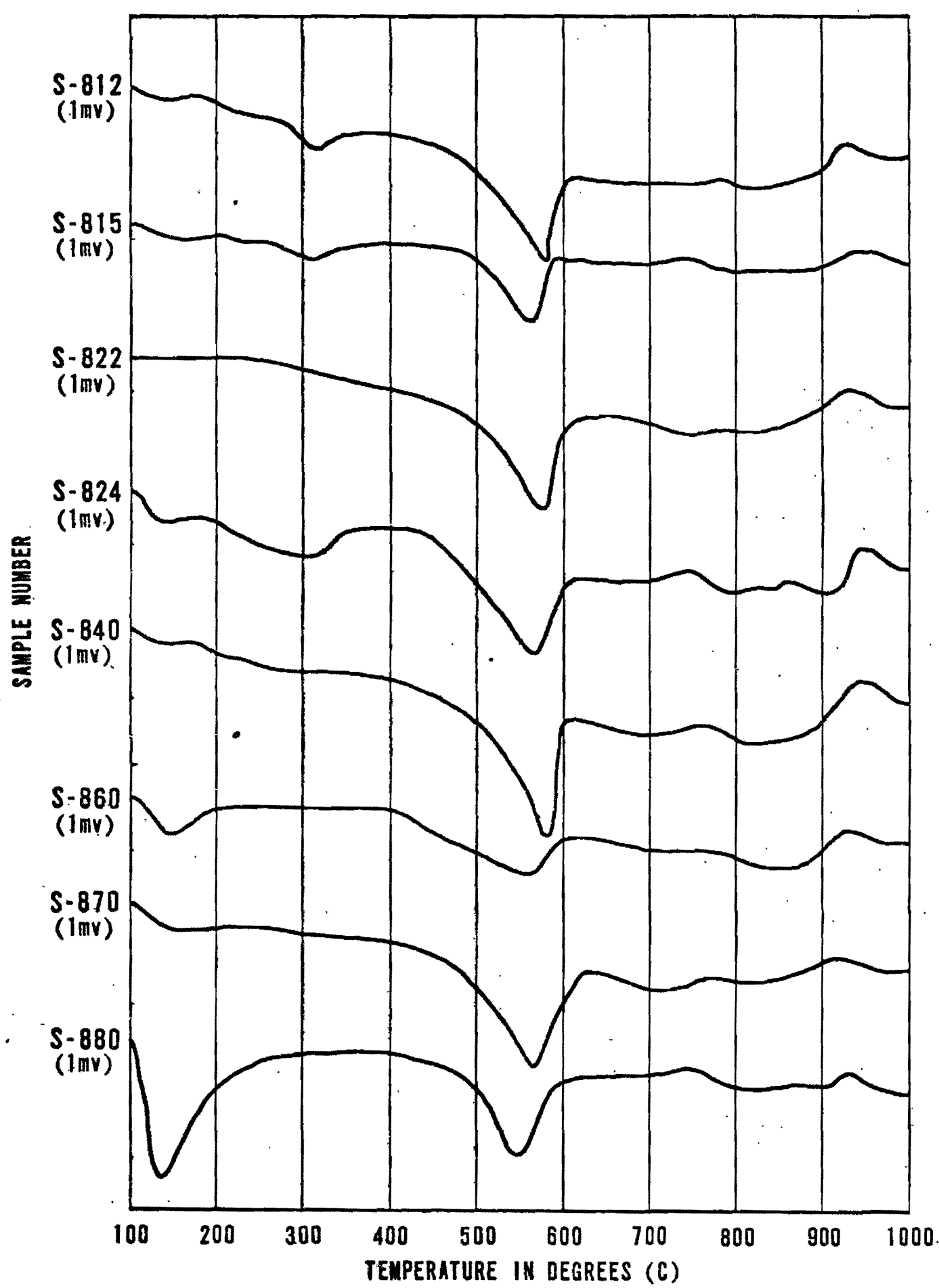

Figure 10. Differential thermal curves of a suite of samples from Wahkiakum County profile B. See text for discussion. 


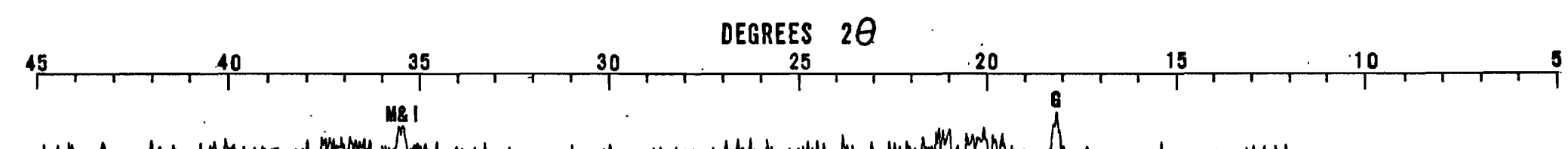

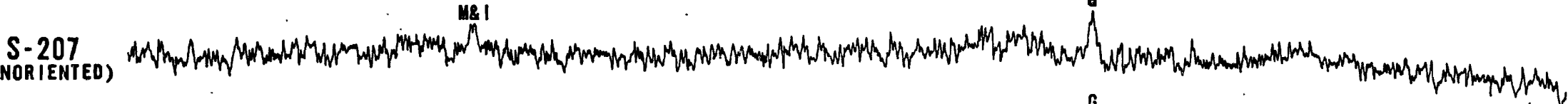

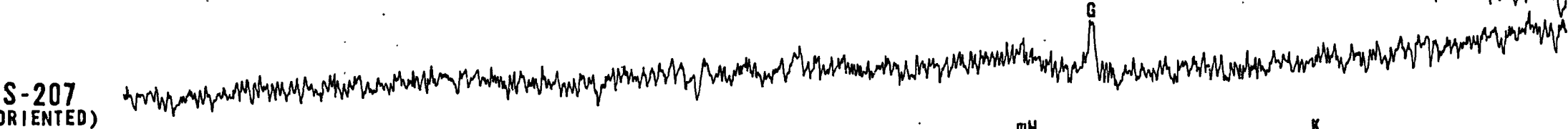
S-205
(UNORIENTED) $\underset{\text { (ORIENTED) }}{S-205}$ S-203 S-203 (UNORIENTED)

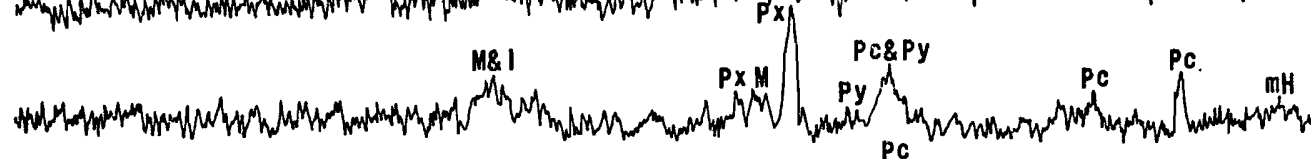

(1)

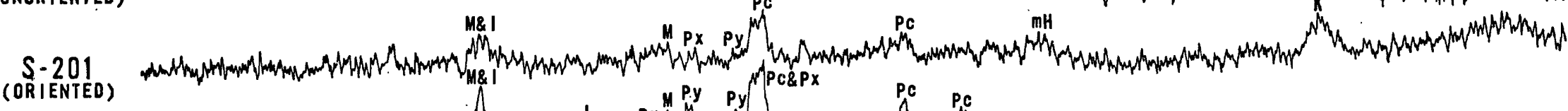
S-2OOC
(UNORIENTED)

$S-200 C$ (ORIENTED)

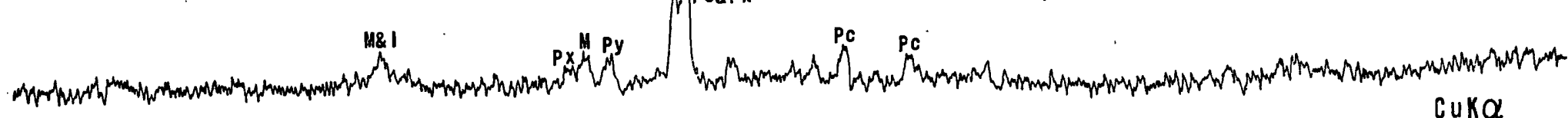

Figure 11. X-ray diffractograms of a suite of samples from basaltic corestone profile.

Px, pyroxene; PC, plagioclase; M, magnetite; I, ilmenite; Py, pyrolusite; mH, metahalloysite;

$K$, kaolinite; G, gibbsite and $S$, smectites. 


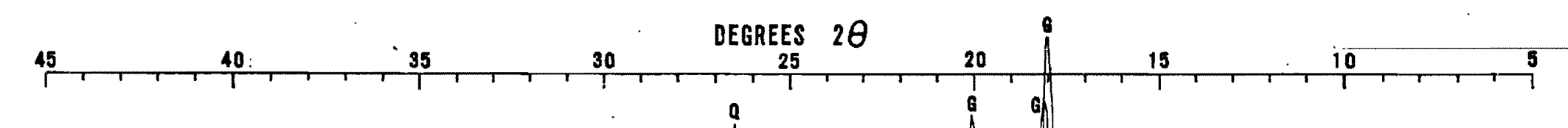

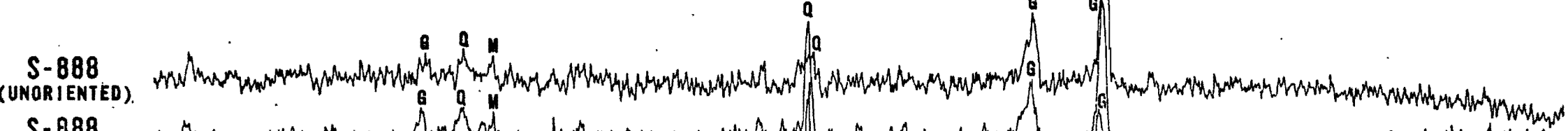

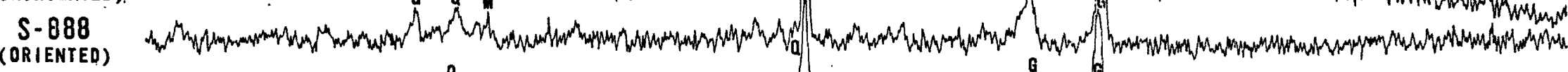

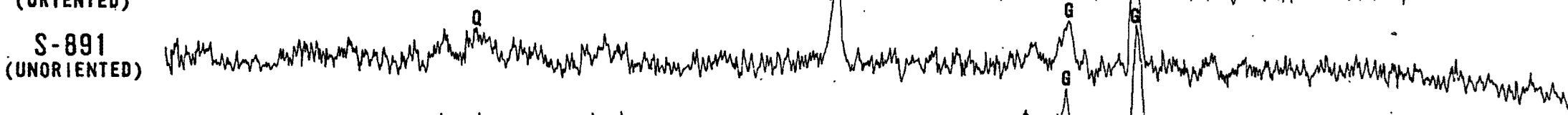

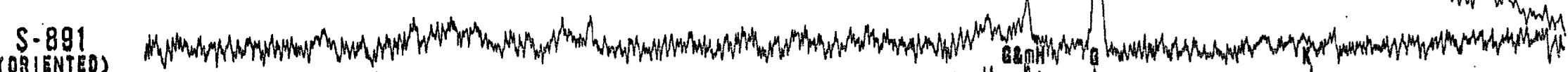

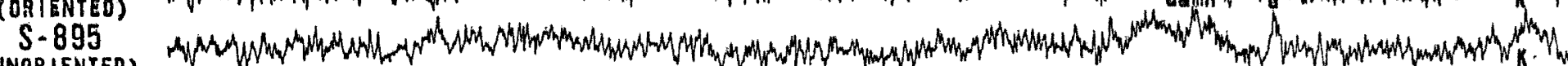

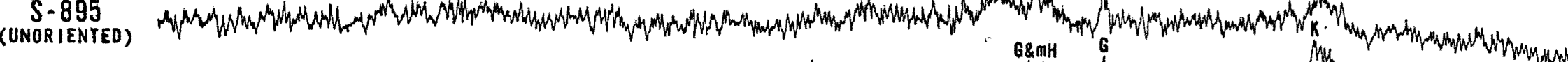

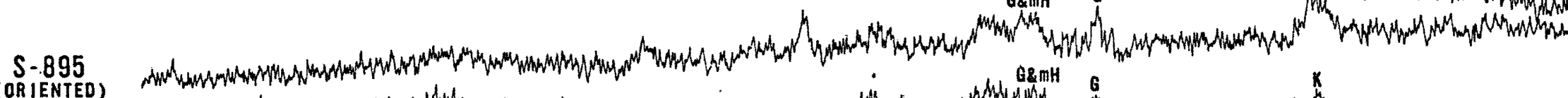

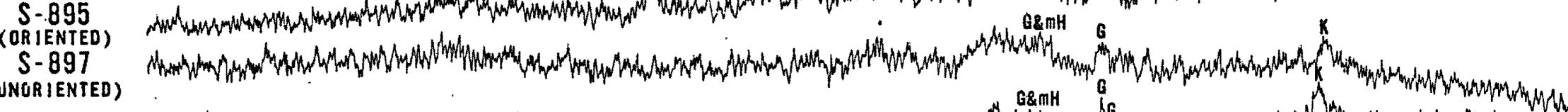

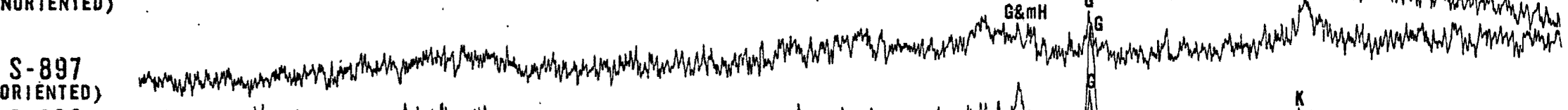
(UNORIENTED)

S- 899

(ORIENTED)

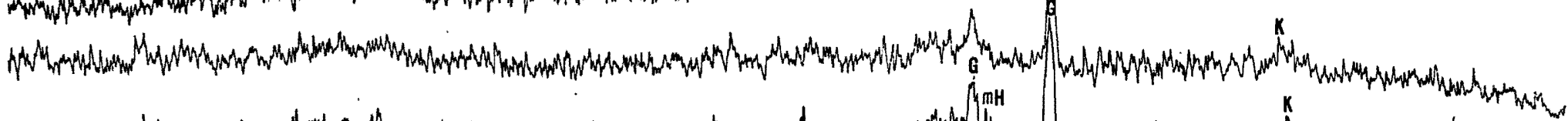

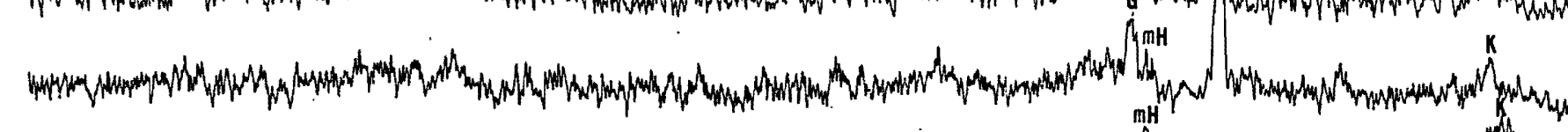

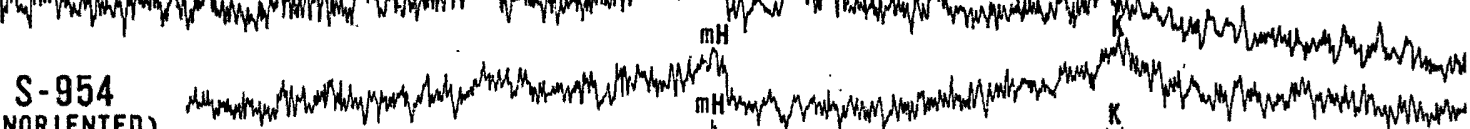

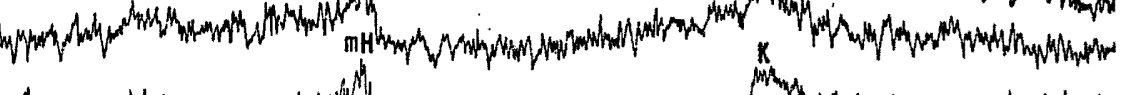
S -954
(OR.IENTED)

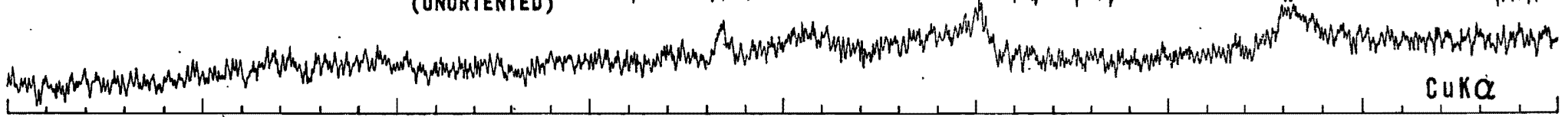

Figure 12. X-ray diffractograms of a suite of samples from Wahkiakum County profile A.

K, kaolinite; $\mathrm{mH}$, metahalloysite; G, gibbsite; $M$, magnetite and $Q$, quartz. 


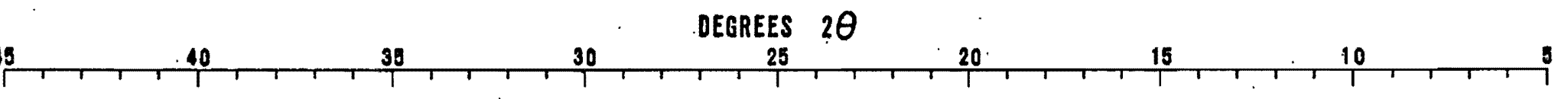

S-812
ONOR IENTED) S-812, S-812,
(ORIENTED)
S-822
UNORIENTED) (UNORIENTED) S-822 (ORIENTED)

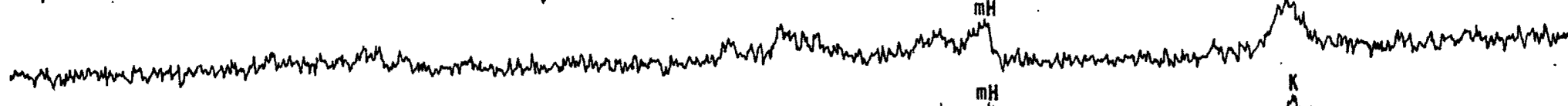
S- 840

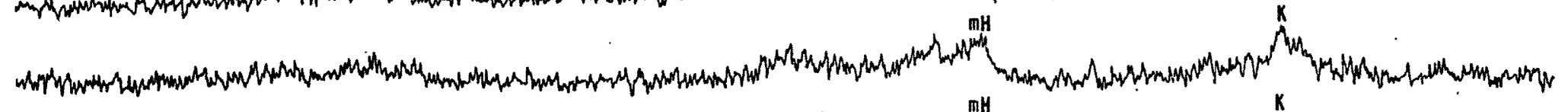
(UNORIENTED)

$S-840$ (ORIENTED)

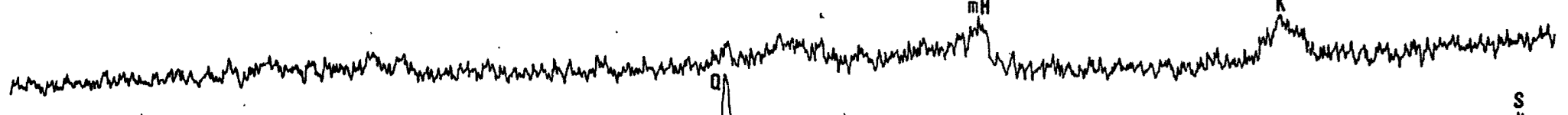
$S-860$ (UNORIENTEO)

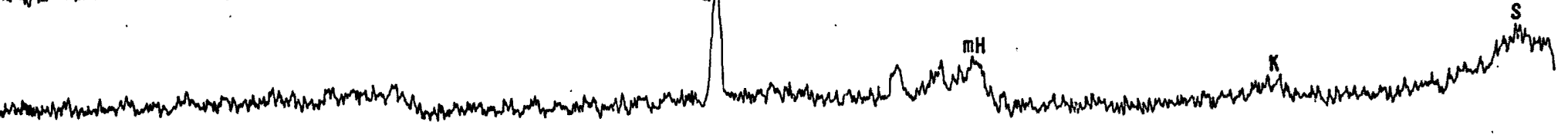
S-860 NOT ANALYZED (ORIENTED) $S-880$ (UNORIENTEO)

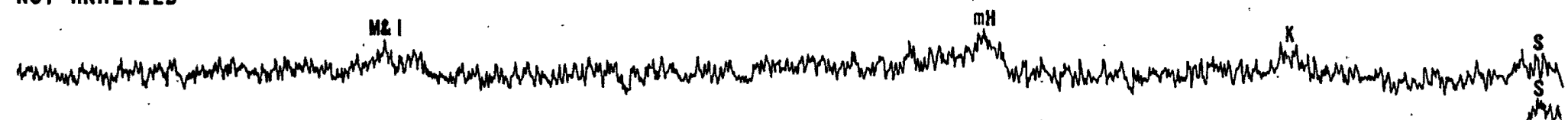

nel 
TABLE IV

IDENTIFICATION OF MINERALS FROM MINERALOGICAL TESTS

\section{MINERAL}

Plagioclase

Magnetite and Ilmenite

Gass
Amorphous
Clay
Kaolinite
.
Met ghalloy-
site

Nontronite

Gibbsite

Diaspore

Cliachite

Limonite

Pyrolusite

Quartz

Siderite
PETROGRAPHIC ${ }^{1}$

Colorless, euhedral to anhedral, commonly lath shaped, low relief, low bire., albite twins common; large $2 \mathrm{~V} ; \mathrm{Bx}(+)$ or $(-)$.

Colorless to light brown, anhedral to euhedral; equant; high relief; mod. bire.; $2 \mathrm{~V}=$ about $20-60^{\circ} ; \mathrm{Bx}(+)$.

Purplish black to steel blue (reflected light); tabular,"crosses and.trains" triangular and rhombic; anhedral to subhedral.

Black, amorphous, with spherulites.

Varicolored; commonly brown, mod. relief.

cloudy to colorless, platy and mosaic aggreg.; low relief; low bire.; unable to obtain $2 \mathrm{~V}$ and optic sign.

Cloudy to colorless; platy and mosaic aggreg.; low relief; very low bire.; unable to obtain $2 \mathrm{~V}$ and optic sign.

Green in reflected light; sometimes brown; fiberous agrreg.; mod. bire.; unable to obtain optic sign and $2 \mathrm{~V}$.

Colorless; fine platy and mosaic aggreg.; mod. relief; mod. bire.; unable to obtain $2 \mathrm{~V}$ and optic sign. Endothermic: about
$350^{\circ} \mathrm{C}$

not identified

Endothermic: about $550^{\circ} \mathrm{C}$

not identified

Red brown; mod. relief; associated with other bauxite minerals.

Yellow brown to orange brown; translucent to opaque; mod. relief; amorphous.

May be black coating on fractures.

Colorless; low relief; low bire.; uniaxial $(+)$.

not determined

not determined

not identified

Colorless, fills vesicles, high

relịef; extreme bire.; uniaxial

negative; does not react to $\mathrm{HCl}$.

$I_{\text {Kerr (1959), and Deer, Howie, and }}$ Zussman (1966). $2_{\text {Grim and Rowland }}$ (1942).

\section{$X$-RAY DIFTRACTION ${ }^{3}$ (ONLY BEST PEAK)}

3: $20^{\circ} \mathrm{A}$ (labradorite andesine)

$2.99^{\circ} \mathrm{A}$ (augite)

2.90 A (pigeonite)

$2.53^{\circ} \mathrm{A}$ (magnetite)

$2.74^{\circ} \mathrm{A}$ (ilmenite)

not determined

not determined

about $7.15^{\circ} \mathrm{A}$

about $4.42^{\circ} \mathrm{A}$

about $13.3^{\circ} \mathrm{A}$

$4.85^{\circ} \mathrm{A}$

not identified

not identified

not determined

$5.14^{\circ} \mathrm{A}$

$3.34^{\circ} \mathrm{A}$
3 Grim (1968) Carroll

(1970), and ASTM (1964). 


\section{Clay minerals}

Amorphous clay (allophane) - Amorphous clay was identified petrographically. Its presence was found in specimens 205 and 207.

Kaolinite - This mineral was positively identified from thin sections and from $x$-ray diffractograms. Kaolinite was recognized in S-201, S-203, S-205, and S-207 (Figure 11). The nature of the $\mathrm{x}$-ray peaks at $7.15^{\circ} \mathrm{A}$ is characteristically low and broad. This may be partly attributed to impurities, poorly crystalline nature, preferred orientation, and/or low total kaolinite content. Kaolinite was not positively identified from DTA curves. Although all specimens show a typical endothermic reaction between $525^{\circ}$ and $560^{\circ}$ centigrade, the corresponding exothermic reaction at $980^{\circ}$ centigrade is absent.

Metahalloysite - This clay mineral was recognized in samples 201, 203, and 205; and identified under the microscope and from $x-r a y$ curves. Iike its counterpart kaolinite, metahalloysite displays a typical low and broad intensity peak.

Nontronite - Nontronite was petrographically identified in S-2OOB; S-200C, S-201, S-203, S-205, and S-207. A broad and low intensity $\mathrm{x}$-ray peak at $13.3^{\circ} \mathrm{A}$ in specimen 205 is tentatively identified as nontronite. Nontronite is not distinguished in DTA curves, but the thermal reactions of several specimens suggests that such a mineral is present.

Bauxite minerals

Gibbsite - This hydrated oxide, is detected in one specimen (S-207) by all three methods. 
Iron minerals

Hematite - This oxide was recognized only petrographically in S-200B, S-200C, S-201, S-203, S-205, and S-207.

Limonite - This amorphous material was detected under the microscope in all specimens studied.

Siderite - Siderite was identified under the microscope in specimens $200 \mathrm{~A}, 200 \mathrm{~B}$, and $200 \mathrm{C}$.

Manganese minerals

Pyrolusite - Pyrolusite was tentatively identified from $\mathrm{x}$-ray tracings in $\mathrm{s}-200 \mathrm{C}, \mathrm{S}-201$, and $\mathrm{s}-203$.

Weathered Zones

The decomposition of the basalt in the corestone is indicated by modal analysis as shown in Figure 14. This diagram depicts the percentage of original constituents remaining in weathered specimens. On the basis of this analysis, the basaltic corestone profile is subdivided into six weathered zones. They have been named: (1) unaltered, (2) iron-rich, (3) slightly weathered, (4) moderately weathered, (5) highly weathered, and (6) ferruginous bauxite. These terms were selected to imply the relative degree of weathering in which the basalt has undergone. Details of each zone are discussed below.

(1) Inaltered basalt zone. The unaltered basalt displays a vesicular hypocrystalline, aphanitic, microporphyritic and intersertal texture (Figure 15). A modal determination shows that this rock con- 
WEATHERED ZONES

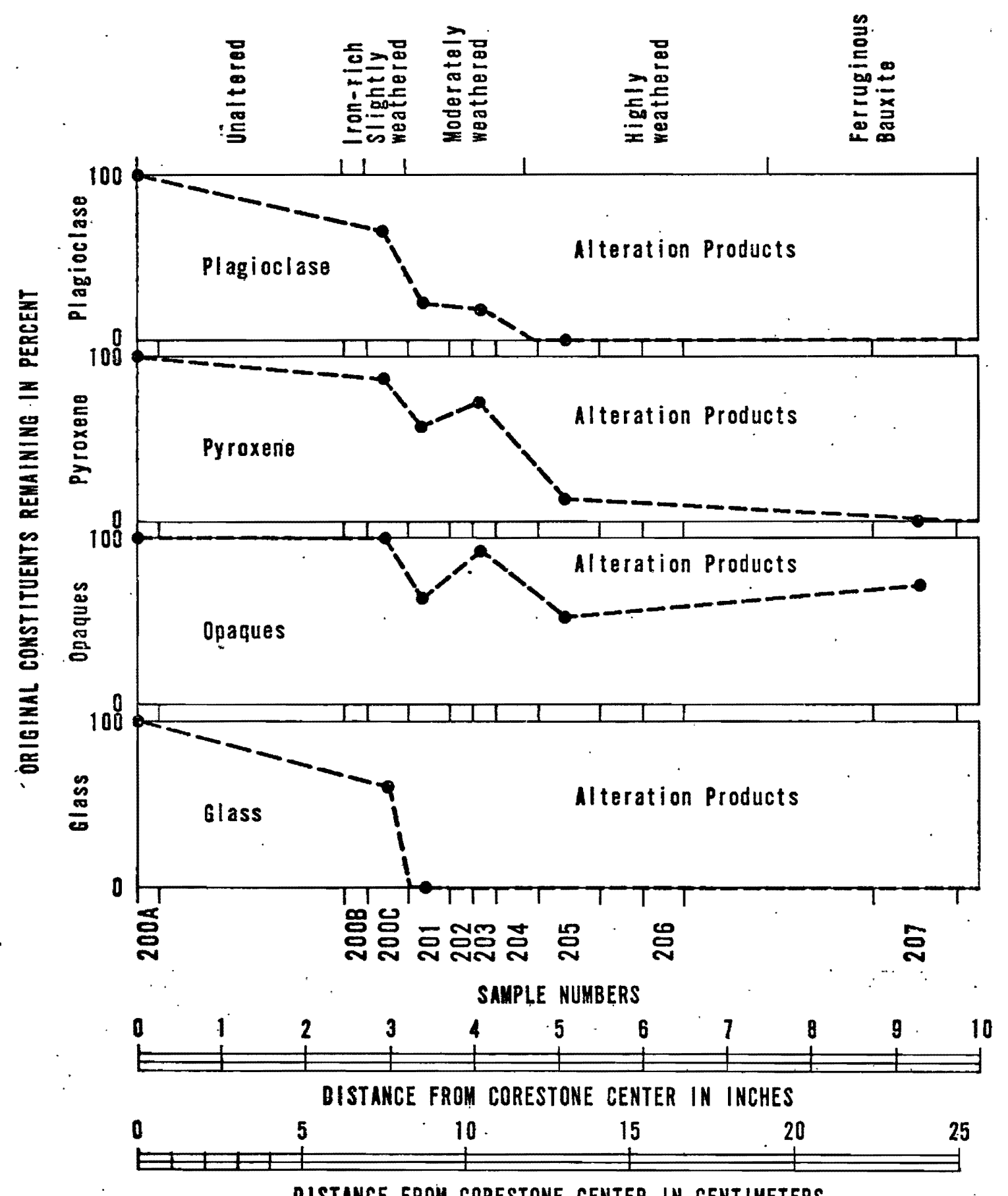

DISTANCE FROM CORESTONE CENTER IN CENTIMETERS

Figure 14. Plot of percentage of original constituents remaining versus the relative degree of weathering in the basaltic corestone profile. Modal analyses of specimens indicated by solid circles. Discussion of weathered zones is in text. 


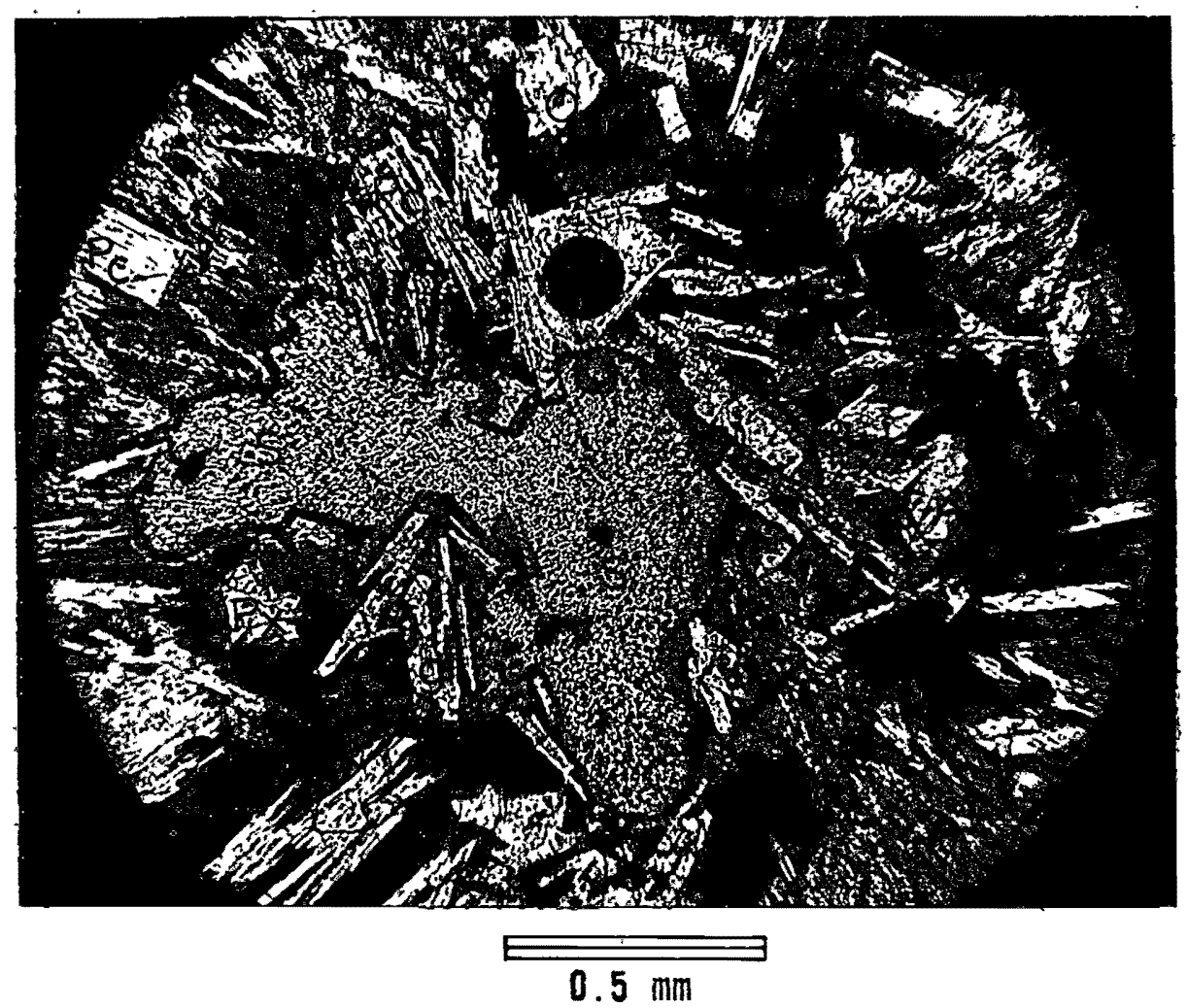

Figure 15. Photomicrograph, plane polarized light, showing unaltered basalt. Basaltic corestone profile (S-200A). Pc, plagioclase; Px, pyroxene; g, iron-rich glass; 0 , opaques and $S$, siderite. See text for discussion. 
sists of plagioclase, 47 percent; pyroxene, 23 percent; opaques, 10 percent; iron-rich glass, 15 percent; and siderite, 5 percent. The plagioclase, $\mathrm{An}_{27}-\mathrm{An}_{44}$, occur as subhedral laths with no preferred orientation. Determination of anorthite content of plagioclase was by methods described by Tobi (1963). Phenocrysts, ranging between $1.0 \mathrm{~mm}$ and $2.0 \mathrm{~mm}$ comprised two to three percent of the total feldspars. Feldspar microlites ranging up to $0.4 \mathrm{~mm}$ make up a large part (47 percent) of the groundmass. Individual crystals are commonly twinned according to the albite law (Deer, Howie and Zussman, 1966). Pyroxene is of two varieties, augite and pigeonite. Most crystals are granules but there are scattered phenocrysts (1-2 percent). Ironrich glass occupies the interstices. Opaques have been identified as magnetite and ilmenite and some are probably intergrown with one another. Most grains are anhedral to subhedral, and range up to $0.7 \mathrm{~mm}$ in length. Siderite occurs as vesicle fillings.

Some minor weathering alteration is present in this zone. A few primary constituents display impurities and iron oxide stains along cleavages and fracture. planes. Along the outer edge of this zone, glass is partly altered to hydrated iron oxides and nontronite.

(2) Iron-rich zone. This zone is characterized by intense enrichment of secondary iron oxides that fill vesicles and replace original and secondary constituents (Figure 5). The secondary iron oxides consist mainly of "blood red" hematite and yellow brown limonite. Both minerals have replaced, in varying degrees, siderite and interstitial glass. Pyroxene and plagioclase crystals display 
some alterations to secondary iron minerals and they are commonly iron stained along cleavages. Opaques appear to be relatively stable, although grain fringes are partly lined with hematite or limonite. Nontronite is not present. An incipient fracture bordering this zone and the unaltered rock may be partly attributed to the enrichment of iron (Figure 5).

(3) Slightly weathered zone. The slightly weathered zone is the first rind that megascopically (Figure 5) and microscopicaily (Figure 16) displays a definite alteration of the original constituents. All minerals, with the exception of the opaques, show corrosion, cloudiness, and mineral decomposition. This zone has this mode: plagioclase, 35 percent; pyroxene, 20 percent; opaques, 10 percent; iron-rich glass, 9 percent; siderite, 1 percent; and alteration products, 25 percent. The primary weathering products are nontronite, hematite, limonite, and siderite.

The major alterations occur primarily in the interstices. where limonite, nontronite, and some hematite have formed from iron-rich glass. Plagioclase laths are commonly corroded and appear to be partly replaced by limonite, nontronite, and other impurities. Along grain boundaries, pyroxene crystals have altered mainly to nontronite, hematite, and occasionally to limonite. Opaque grains are unweathered as indicated by the modal analysis (Figure 14). Siderite is decomposing to hematite and limonite. In many places, limonite stains cleavages and fractures. 


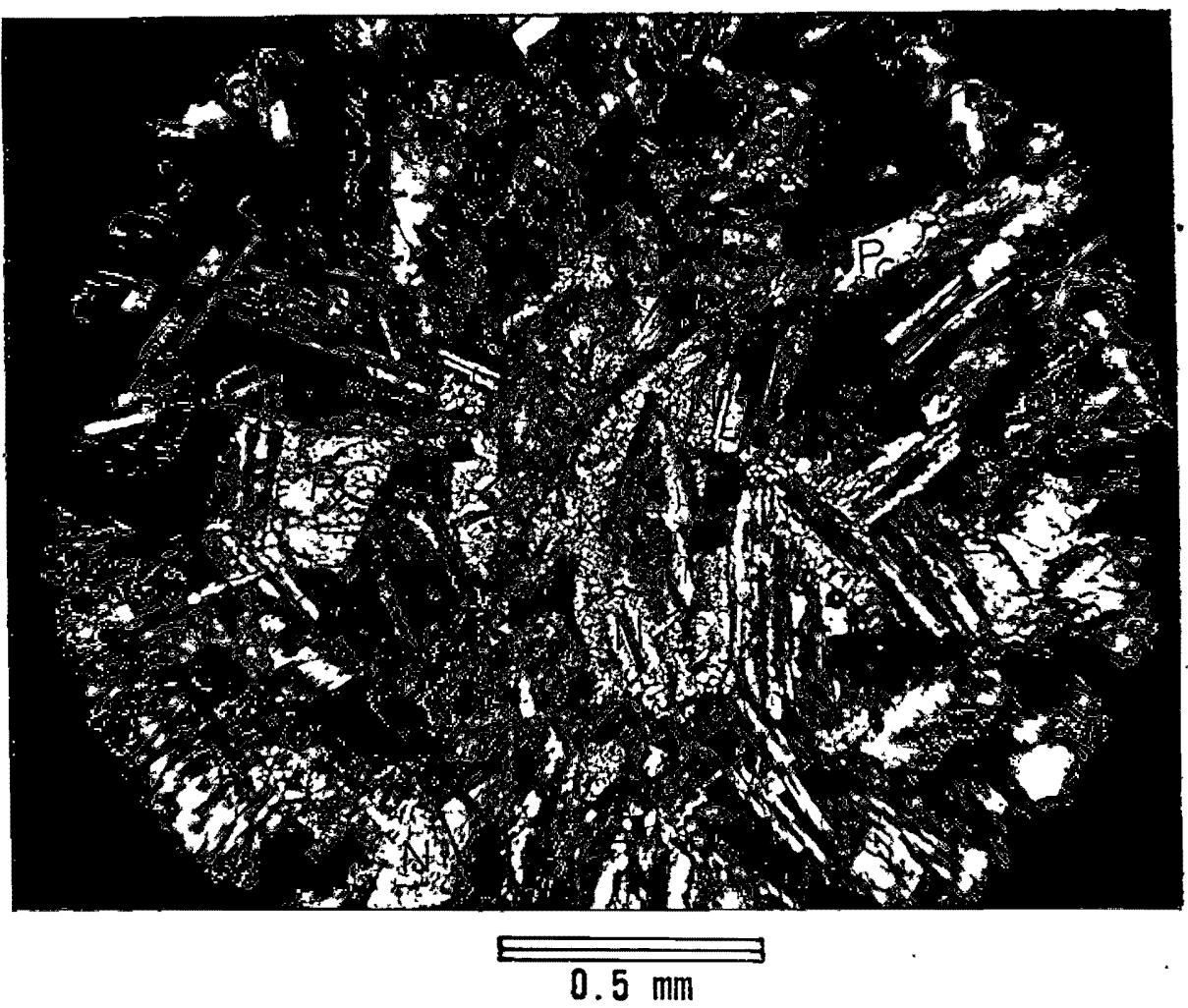

Figure 16. Photomicrograph, cross polarizers, showing slightiy weathered zone. Basaltic corestone profile (S-200C).

Pc, plagioclase; Px, pyroxene; g, i ron-rich glass; 0 , opaques; $N$, nontronite and $L$, limonite. See text for discussion. 
(4) Moderately weathered zone. The moderately weathered zone shows a greater degree of alteration than the previously discussed zones (Figure 17). Although some minerals are entirely weathered, their original crystal shapes are preserved in places. The mineral composition of samples 201 and 203, respectively are: plagioclase, 10 and 8 percent; pyroxene, 13 and 13 percent; opaques, 6 and 9 percent; and weathering products 71 and 67 percent.

Alteration products include kaolinite, metahalloysite, nontronite, hematite, limonite, and pyrolusite.

Plagioclase feldspars display a varied degree of weathering from core alterations to total decomposition. Kaolinite and metahalloysite (?) are the major alteration products. Limonite, occurring in lesser amounts, is also associated with the plagioclase laths. Some pyroxene grains have been replaced by nontronite and limonite, while others display varying degrees of corrosion. Interstitial glass has wholly weathered to nontronite, hematite, and limonite. Although the modal analysis seems to indicate a depletion of the opaques, these minerals exhibited little observable alterations. Hematite lines some secondary formed voids. In addition, hematite appears to have partly altered to limonite. Pyrolusite was not identified petrographically, but its occurrence is indicated by black stains along exfoliation joints.

(5) Highly weathered zone. The rock has undergone a profound mineralogical change as a result of weathering (Figure 18). Alteration products comprise about 92 percent of the rock and the remaining eight percent is made up of original constituents. Kaolinite, metahalloysite, 


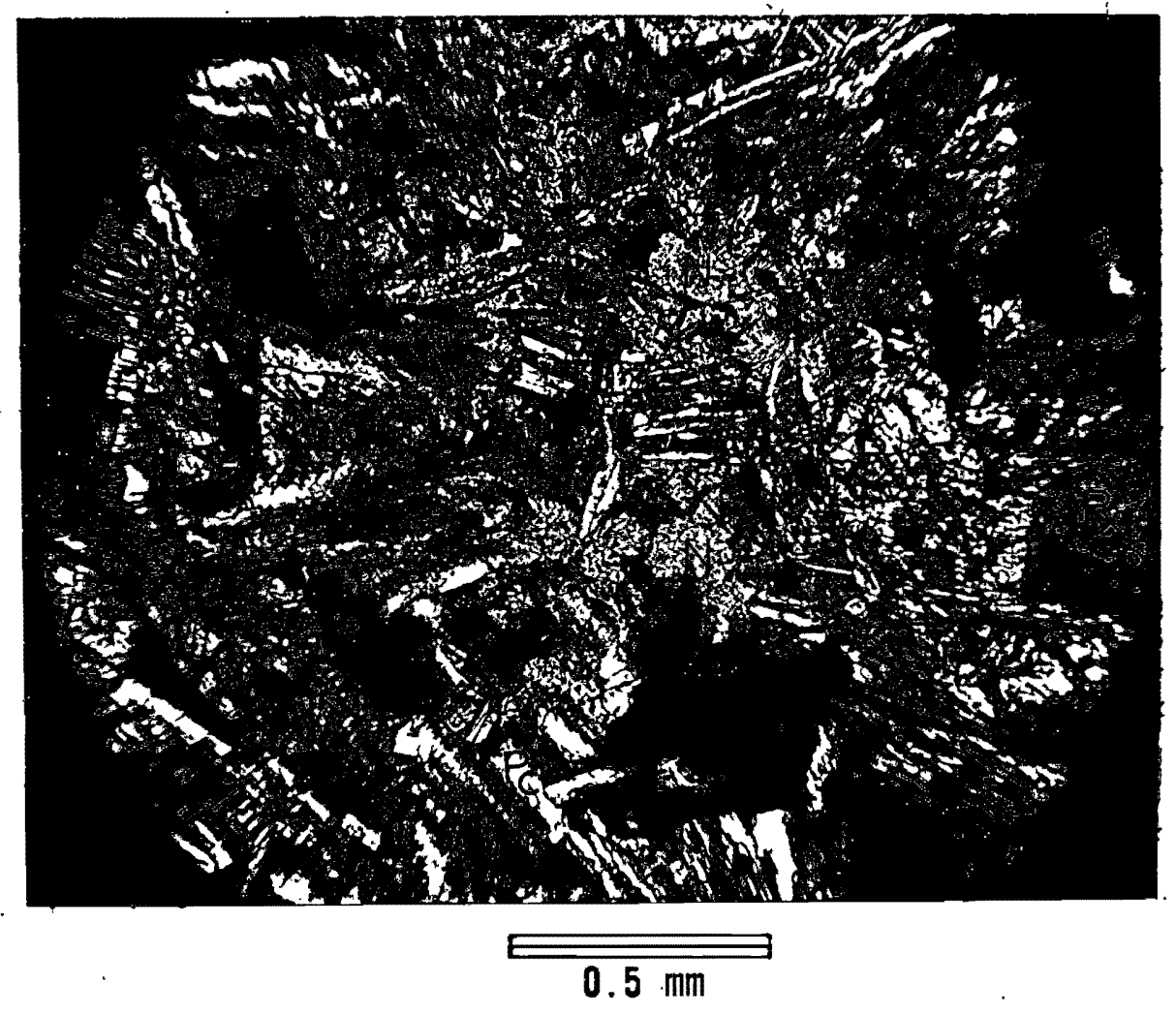

Figure 17. Photomicrograph, cross polarizers, showing moderately weathered zone. Basaltic corestone profile (S-203). Pc, plagioclase; Px, pyroxene; 0 , opaques; $K$, kaolinite; $m H$, metahalloysite; $N$, nontronite and $L$, Iimonite. See text for discussion. 


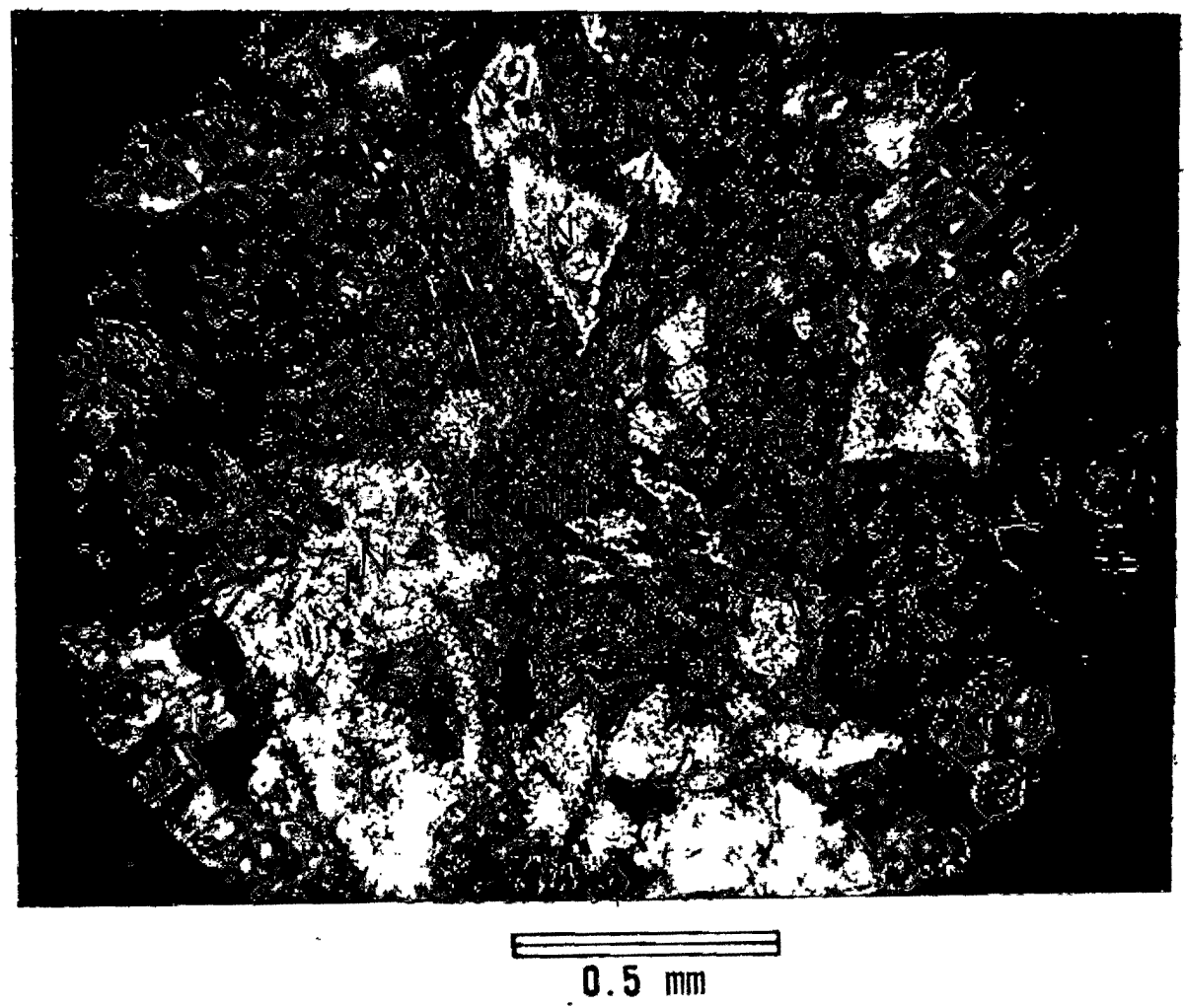

Figure 18. Photomicrograph, eross polarizers, showing highly weathered zone. Basaltic corestone profile $(S-205)$. Dark gray areas consist mostly of cloudy kaolinite and/or metahalloysite (?) and limonite. Pc, plagioclase; Px, pyroxene; 0 , opaques; $N$, nontronite; $K$, kaolinite; mH, metahalloysite and L, limonite. See text for discussion. 
nontronite, brown amorphous clays, hematite, and limonite are the primary weathering products, and the unaltered constituents consist mainly of pyroxene ( 3 percent), opaques ( 5 percent); and a trace of plagioclase.

Microscopically, the basaltic texture is nearly obliterated, and megascopically the decomposed rock displays a salt and pepper texture. Amorphous material is common, particularly in the form of limonite and amorphous clay.

A few remanent slivers of plagioclase laths are the only remains of this mineral. The rest have altered to cloudy kaolinite, amorphous clay (allophane), and a very low birefringent material (metahalloysite ?). Numerous plagioclase laths are altered beyond recognition. Pyroxene granules in the groundmass are entirely weathered, but several phenocrysts are only partly altered. Pyroxene is altered primarily to blood red hematite, amorphous clay, limonite, and nontronite. Hematite has formed around and intruded some pyroxene grains in the form of clots and irregular masses. Magnetite and ilmenite display very little alteration, except where they are obscured by heavy iron oxide stains. Amorphous clay seemingly is associated with nearly all minerals (except opaques).

Several authigenic minerals appear to have been precipitated from water solutions. Both nontronite and hematite are lining and filling voids; and in places they occur in botryoidal form. Kaolinite is a filling. in veinlets.

In this zone, some alteration products may be partially altered. Hematite and nontronite appear to be decomposing to limonite. 
(6) Ferruginous bauxite zone. This zone is more highly weathered than the other zones in the profile (Figure 19). Almost all of the original silicate minerals are altered with the exception of a few pyroxene phenocrysts. The original texture is nearly obliterated.

Ninety-three percent of the rock is composed of weathering products. The remaining seven percent consist of unaltered opaques and a trace of pyroxene grains. The predominant weathering products, in order of abundance, are amorphous clay, limonite, and hematite. Other minor secondary mineral's are nontronite, gibbsite, kaolinite, and metahalloysite. Gibbsite lines veinlets and also occurs as patchy masses. Microscopically, gibbsite appears to have formed partially from amorphous clay.

\section{WAHKIAKUM COUNTY PROFILE A}

Presentation of Analysis

Original constituents. Five original constituents were identified petrographically. They are: plagioclase, pyroxene, iron-rich glass, opaques, and quartz. Their optical properties are listed in Table IV.

Alteration constituents. A total of nine alteration products were identified-in a suite of specimens from this profile: kaolinite, metahalloysite, nontronite, amorphous clay, gibbsite, diaspore, cliachite, hematite, and Iimonite. 


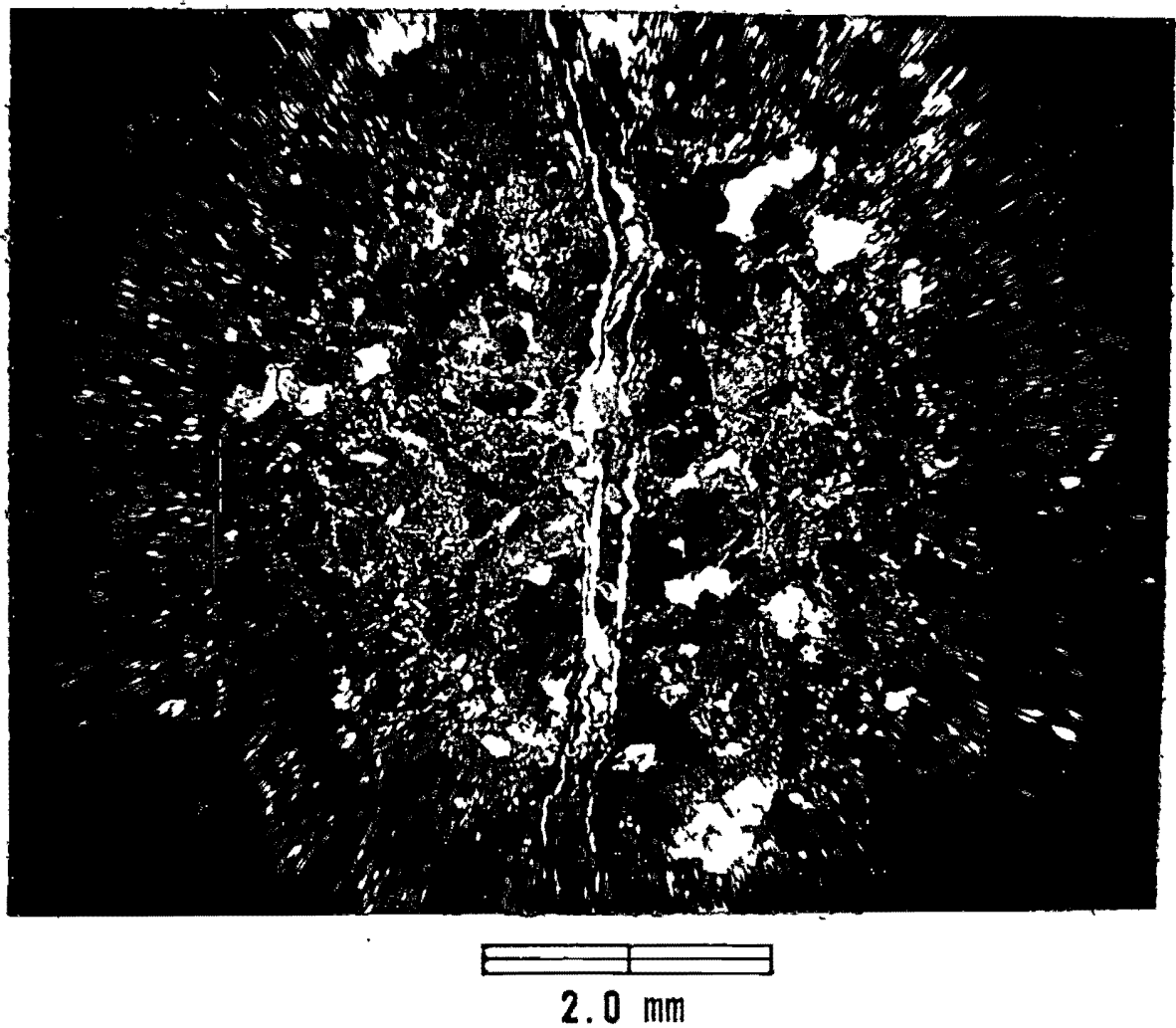

Figure 19. Photomicrograph, cross polarizers, showing ferruginous bauxite zone. Basaltic corestone profile (S-207). Dark areas consist primarily of amorphous $c$ lay and limonite. Lighter areas consist of kaolinite, gibbsite and hematite. Gibbsite (bright white) lining veinlets in center of photomicrograph. Driginal texture is very faint. See text for discussion. 


\section{Clay minerals}

Amorphous clay - This material was identified petrographically in samples $954 \mathrm{~A}$ and 954 . It is the opinion of this writer that amorphous clay may be present in other samples, but petrographic studies were not performed on other specimens. Amorphous clay was not identified by DTA.

Kaolinite and metahalloysite - These two clay minerals were identified under the microscope, from thermal curves, and x-ray diffractograms. Kaolinite and metahalloysite were identified in specimens $954 \mathrm{~A}$, 954, 999, 997, and 895. In $\mathrm{x}$-ray diffraction, these minerals display a typical broad and low intensity peak. Thermal curves of samples 893 , 895,897 , and 954 show an endothermic reaction between $550^{\circ} \mathrm{C}$ and $580^{\circ} \mathrm{C}$ and an associated exothermic reaction between $900-950^{\circ} \mathrm{C}$ which is much the same as that of a kaolinite mineral (Grim and Rowland, 1942).

Nontronite - This clay mineral was microscopically identified in specimens 954 and $954 \mathrm{~A}$. Its presence was not detected in the diffractograms. The thermal peaks of specimens 954,897 , and 893 are similar to those described by Grim and Rowland (1942). Smectites have an endothermic peak between $100^{\circ} \mathrm{C}-250^{\circ} \mathrm{C}, 500^{\circ} \mathrm{C}-560^{\circ} \mathrm{C}$, and another at $900^{\circ} \mathrm{C}$; and an exothermic reaction between $900^{\circ} \mathrm{C}$ and $1000^{\circ} \mathrm{C}$.

\section{Bauxite minerals}

Gibbsite - Gibbsite was positively identified in specimens 954 , $899,897,893,891 \mathrm{~A}, 891$, and 888 by all three methods.

Diaspore - This bauxite mineral was tentatively identified in samples 891 and $891 \mathrm{~A}$ from thermal curves. 
Cliachite - This amorphous bauxite mineral was petrographically identified in specimen 888 .

Iron minerals

Hematite and limonite - These two minerals were identified under the microscope in specimens 954A, 954, and 888. A strong endothermic reaction at $340^{\circ} \mathrm{C}$ in specimens 888 and 891 is partly attributed to limonite. Hematite was not identified from $x$-ray diffractograms. Magnetite - Secondary magnetite was tentatively identified in specimen 888 by x-ray diffraction. Magnetite and ilmenite were observed in all specimens examined.

\section{Weathered Zones}

The Wahkiakum County Profile A is divided into four weathered zones: (1) moderately weathered, (2) highly weathered, (3) ferruginous bauxite, and (4) ferruginous bauxite ore. Unlike the basaltic corestone, the unaltered, iron-rich, and slightly weathered rocks were not detected in this profile. Gray basaltic corestones were penetrated at the bottom of the boring, and a microscope examination reveals that the rock is moderately weathered. Photomicrographs of specimens $954 \mathrm{~A}$, 954, and 888 are included to illustrate three of the weathered zones.

\section{(1) Moderately weathered zone. At the bottom of this section} are scattered bJ.ocks of gray and moderately weathered basalt, embedded in clay (decomposed basalt). The rock is fine-grained, slightly porphyritic, and slightly vesicular. A microscopic examination of a 
corestone reveals an original composition of plagioclase (est. 45 percent), pyroxene (est. 22 percent), iron-rich glass (est. 31 percent), and black opaques (est. 2 percent) (Figure 20).

The alteration of most feldspars prevented determination of their composition by petrographic methods. Pyroxene crystals are of two varieties, augite and pigeonite, and they are commonly found as equant and anhedral granules in the groundmass. A few pyroxene phenocrysts are also present. Magnetite and ilmenite are intergrown with one another as is indicated by their "crosses and trains" form. They also occur as minute irregular masses and slivers. Interstitial glass is highly loaded with impurities (magnetite dust ?).

A microscopic examination of the weathered basalt shows that 50 to 60 percent of the original constituents have altered to kaolinite, metahalloysite, amorphous clay, or nontronite; however, the original texture is well preserved. The dominate mineralogical changes as a result of weathering are associated with plagioclase and interstitial glass. Kaolinite and metahalloysite tend to form from plagioclase, but some kaolinite lines voids. Nontronite and amorphous clay are the chief weathering products from glass and pyroxene.

(2) Highly weathered zone. The highly weathered zone lies within a few inches from the moderately weathered zone (Figure 21). Petrographic examination shows that the basalt is altered almost entirely to a variety of weathering constituents. The only remaining primary minerals are the opaques and portions of pyroxene phenocrysts. 


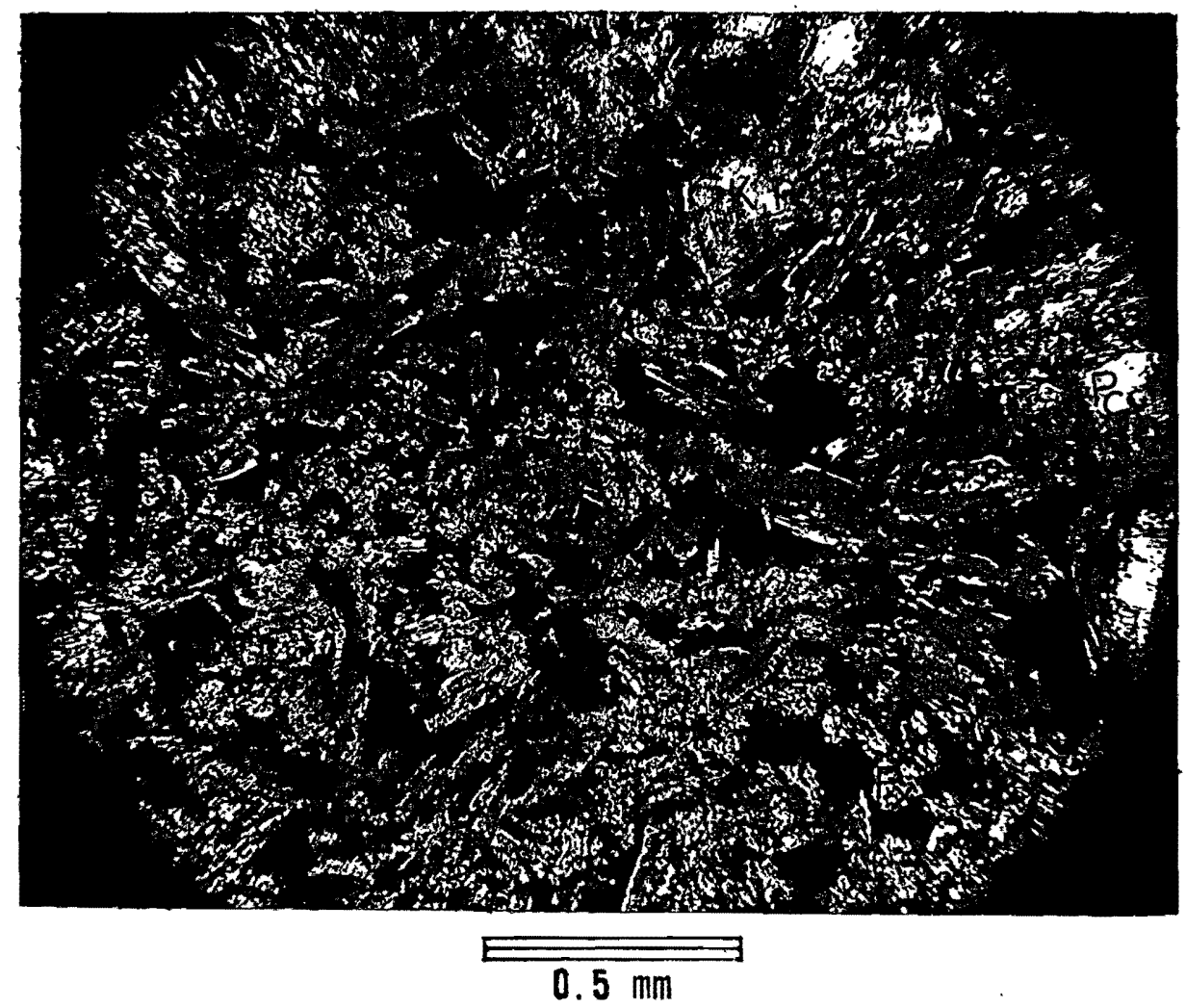

Figure 20. Photomicrograph, cross polarizers, showing moderately weathered zone. Wahkiakum County profile A (S-954A). Plagioclase have altered to kaolinite minerals, except along some edges.

Pyroxene granules are highly corroded. Dark shaded areas consist of amorphous materials that have formed from intersertal glass. $\mathrm{Pc}, \mathrm{plagioclase;} \mathrm{Px}$, pyroxene; $K$, kaolinite and $\mathrm{mH}$, metahalloysite. See text for discussion. 


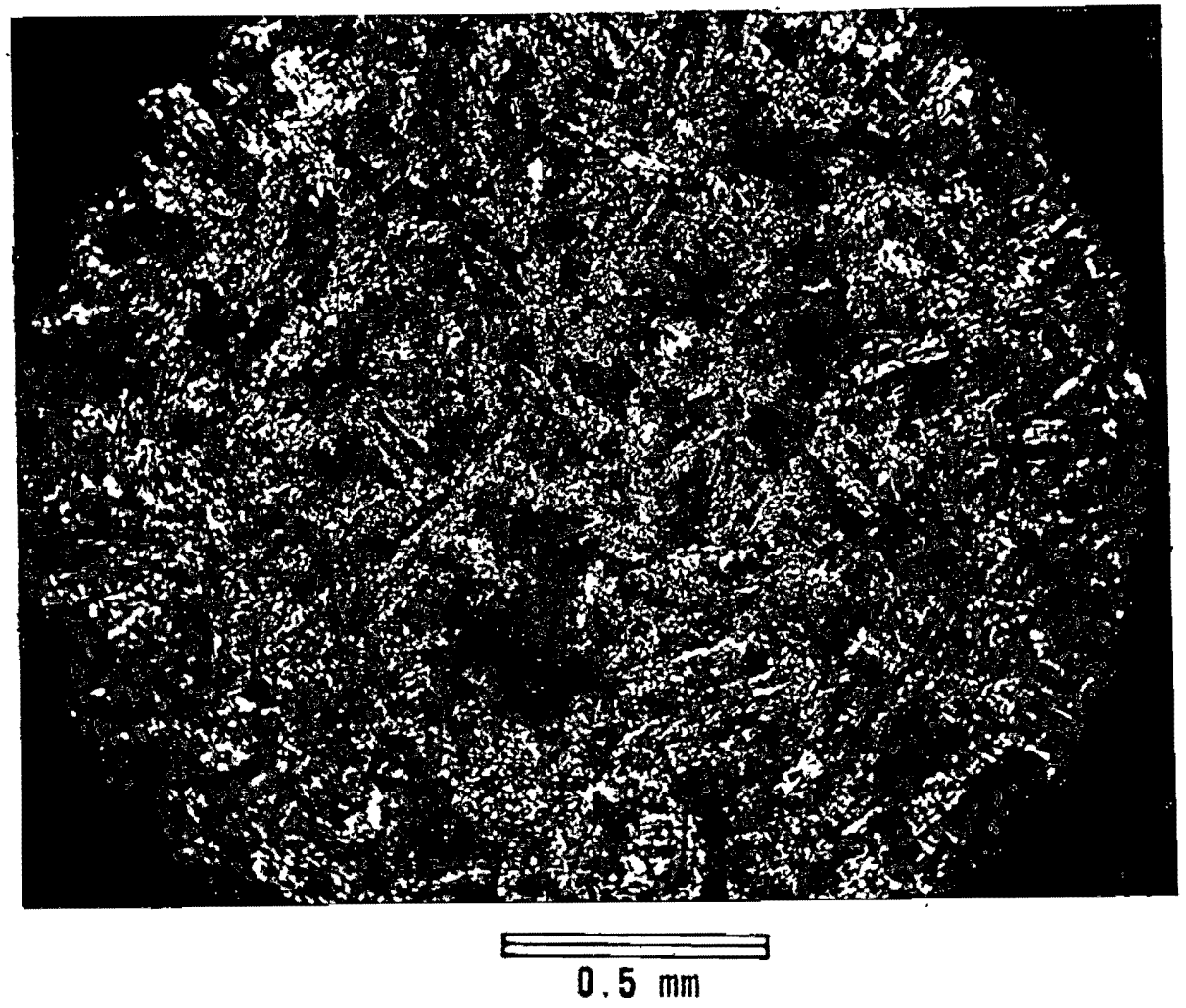

Figure 21. Photomicrograph, cross polarizers, showing highly weathered zone. Wankiakum County profile A $(S-954)$. Kaolinite and metahalloysite pseudomorphs after plagioclase (gray areas). Shaded gray areas consist mainly of limonite. Very light areas represent mostiy nontronite and hematite; and some unaltered pyroxenes and remnant plagioclase slivers. K, kaolinite; $\mathrm{mH}$, metahalloysite; $P c$, plagioclase; $P x$, pyroxene; 0 , opaques and L. limonite. See text for discussion. 
Alteration products identified are'kaolinite, metahalloysite, hematite, limonite, nontronite, and amorphous clay. Hematite is a pseudomorph of pyroxene grains. Feldspars are decomposed to kaolinite and metahalloysite, without much destruction of the original Iaths. Iimonite stains all minerals and is commonly a product of interstitial glass. Nontronite and amorphous clay are scattered in the groundmass. Opaque grains do not appear to be decomposed.

The basalt texture is evident even though the rock has deteriorated to clay.

(3) Ferruginous bauxite zone. Thin sections of this zone were not prepared. Megascopically, a salt and pepper texture was common throughout this section.

AIteration minerals identified from $x$-ray and DTA records are kaolinite, metahalloysite, gibbsite, and nontronite. Also, amorphous clay is thought to exist in varying amounts, on the basis of other profiles studied.

Kaolinite, metahalloysite, and gibbsite are present throughout this section. The percentages of these minerals are not determined, but if one assumes that the relative peak intensities from thermal curves is a valid indicator, then their amounts are minor.

(4) Ferruginous bauxite ore zone. Overlying the ferruginous bauxite zone is the ore zone which consists of a lower nodular bauxite unit and an upper pisolitic unit. The ore zone contains usually less than 10 percent non-reactive silica. Detailed descriptions of this 
material is described by Livingston (1966) and Jackson (1971). Because of the distinct textural appearance of the ore zone, it can readily be distinguished from the overlying silty clay and the underlying clay (ferruginous bauxite zone).

The ferruginous bauxite ore.zone consists primarily of cliachite, limonite, gibbsite, and diaspore. Gibbsite is the major mineral constituent in the nodules; and cliachite and gibbsite largely occur in the earthy bauxite matrix. The pisolites and oolites are composed of limonite and minor amounts of gibbsite. Diaspore is found in trace amounts in the nodular horizon.

A mineral that has not been given much attention in published bauxite literature (Pacific Northwest area) is quartz. Numerous quartz grains are embedded in the pisolites and bauxite matrix in profile A (pisolitic unit). The grains are mostly silt in size, but some reach $0.75 \mathrm{~mm}$, and are angular to subrounded (Figure 22). The texture of the grains suggest a detrital origin, and do not appear to be formed from weathering processes. The presence of residual quartz grains in the ore zone is not completely understood. During bauxitization, quartz encased in the iron-rich pisolites could be preserved, because limonite is relatively stable. However, it does not seem possible for quartz to survive in the earthy bauxite matrix for a prolonged period of weathering. A possible source rock for the pisolitic unit is the lower portion of the Post-Troutdale silty clay. 


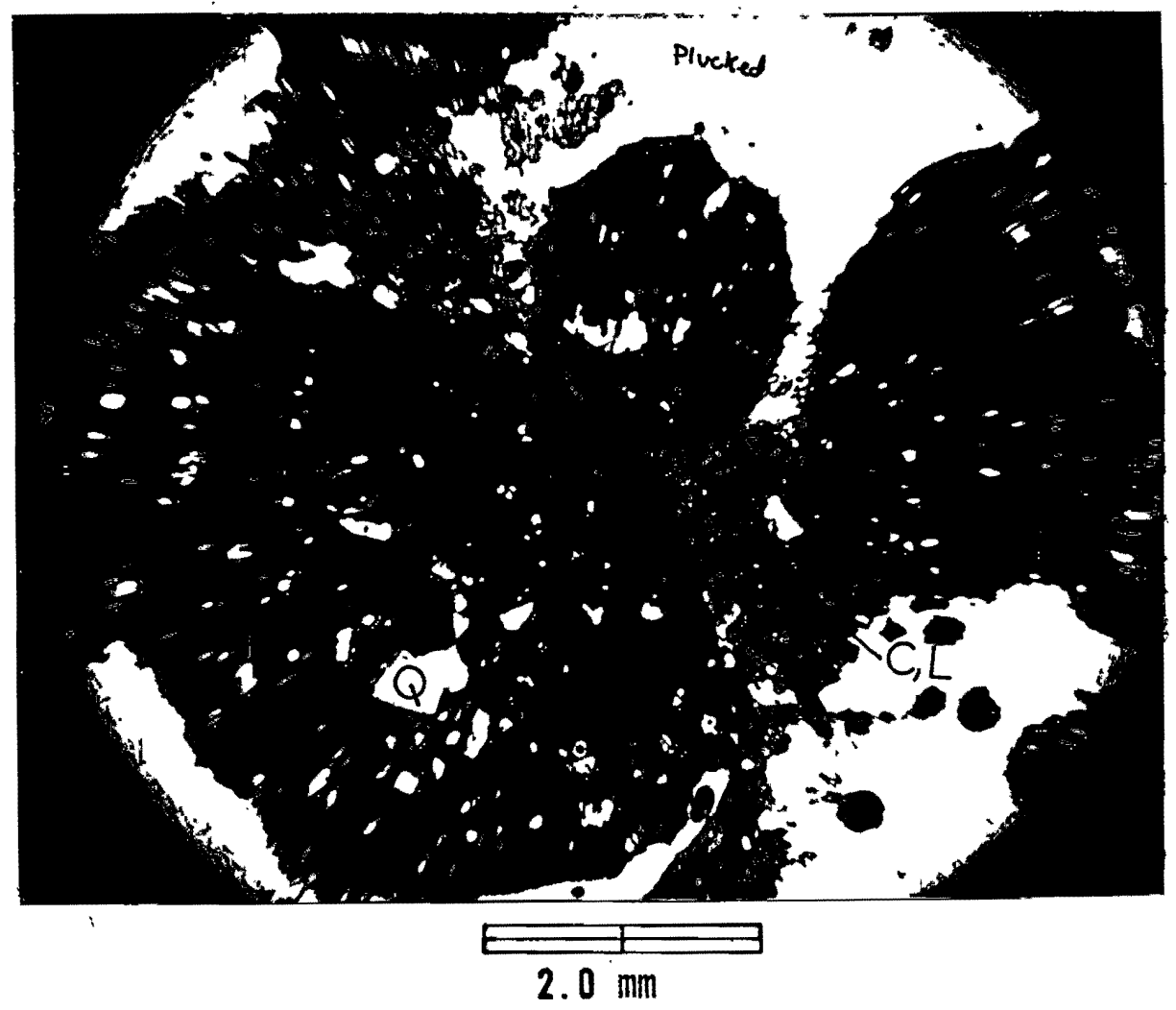

Figure 22. Photomicrograph, plane polarized light, showing pisolitic material characteristic of ferruginous bauxite ore zone. Wahkiakum County profile A $(S-888)$. Note the angular to subround detrital quartz grains embedded in the iron-rich pisolites and bauxite matrix. L, limonite; C, cliachite and Q, quartz. See text for discussion. 


\section{WAHKIAKUM COUNTY PROFILE B}

Presentation of Analysis

Original constituents. Opaques (magnetite and ilmenite) are the only remaining primary constituents identified from diffractograms in specimen 880 and under the microscope in specimens 840,822 , and 812 . Quartz was positively identified in specimen 860 (sedimentary interbed) from $x$-ray diffraction patterns and was observed under a 10-power hand Iens.

Alteration constituents. Five alteration constituents identified from the mineralogical analysis are kaolinite, metahalloysite, smectite. mineral (species unknown), gibbsite, and amorphous clay.

\section{Clay minerals}

Amorphous clay - This material was detected in specimens 840 and 822, petrographically. In both specimens it appears to be the major component.

Kaolinite and metahalloysite - Kaolinite and metahalloysite were identified from $x$-ray diffractograms in specimens $880,860,840,822$, and 812. A kaolinite-type mineral was identified from DTA curves in specimens $880,870,860,840,824,822,815$, and 812 . Peaks displayed in the thermal and $\mathrm{x}$-ray records are low and broad for these minerals.

Smectite - This group was tentatively identified in specimens 880 and 860 . Specimen 860 has a highly expansive property in water. 


\section{Bauxite minerals}

Gibbsite - This bauxite mineral was tentatively identified in specimens 812,815 , and 824 from thermal curves.

Weathered Zones

In contrast to the previously discussed profiles, unaltered basalt was not penetrated even at a depth of 165.0 feet $(50.3 \mathrm{~m}$ ) (below ground surface). In addition, sedimentary rocks are interbedded in the basalt flows.

Wahkiakum County profile $B$ is subjectively divided into three major zones: (I) highly weathered zone, (2) sedimentary interbeds, and (3) ferruginous bauxite zone. The zones are named on the basis of similar material found on the basaltic corestone profile and profile A.

(1) Highly weathered zone. Minerals identified in this zone are magnetite, ilmenite, kaolinite, halloysite, and a smectite mineral. Ilmenite and magnetite are probably primary in origin and residual minerals from the basalt. Megascopically, the decomposed rock displays a relict basalt texture. Plagioclase laths are enlarged and bleached. Probably, plagioclase weathers to kaolinite and metahalloysite. A smectite mineral identified in $x$-ray diffractograms may be an alteration mineral formed from mafic minerals and basaltic glass.

(2). Sedimentary interbeds. Intercalated with the laterized 
basalt are highly weathered sedimentary rocks consisting of a lower pebble to cobble conglomerate and an upper silty claystone unit. Clasts of volcanic composition are wholly altered to clay. Clay minerals present in the claystone are kaolinite and a smectite mineral.

(3) Ferruginous bauxite zone. The ferruginous bauxite zone totals nearly 100 feet $(30.5 \mathrm{~m})$ of laterized basalt. Based on petrographic studies, amorphous clay is the major component (Figure 23). Gibbsite in association with kaolinite minerals exists in the upper portion of the zone. Residual opaques characterized by their "crosses and trains" shape were also observed. 


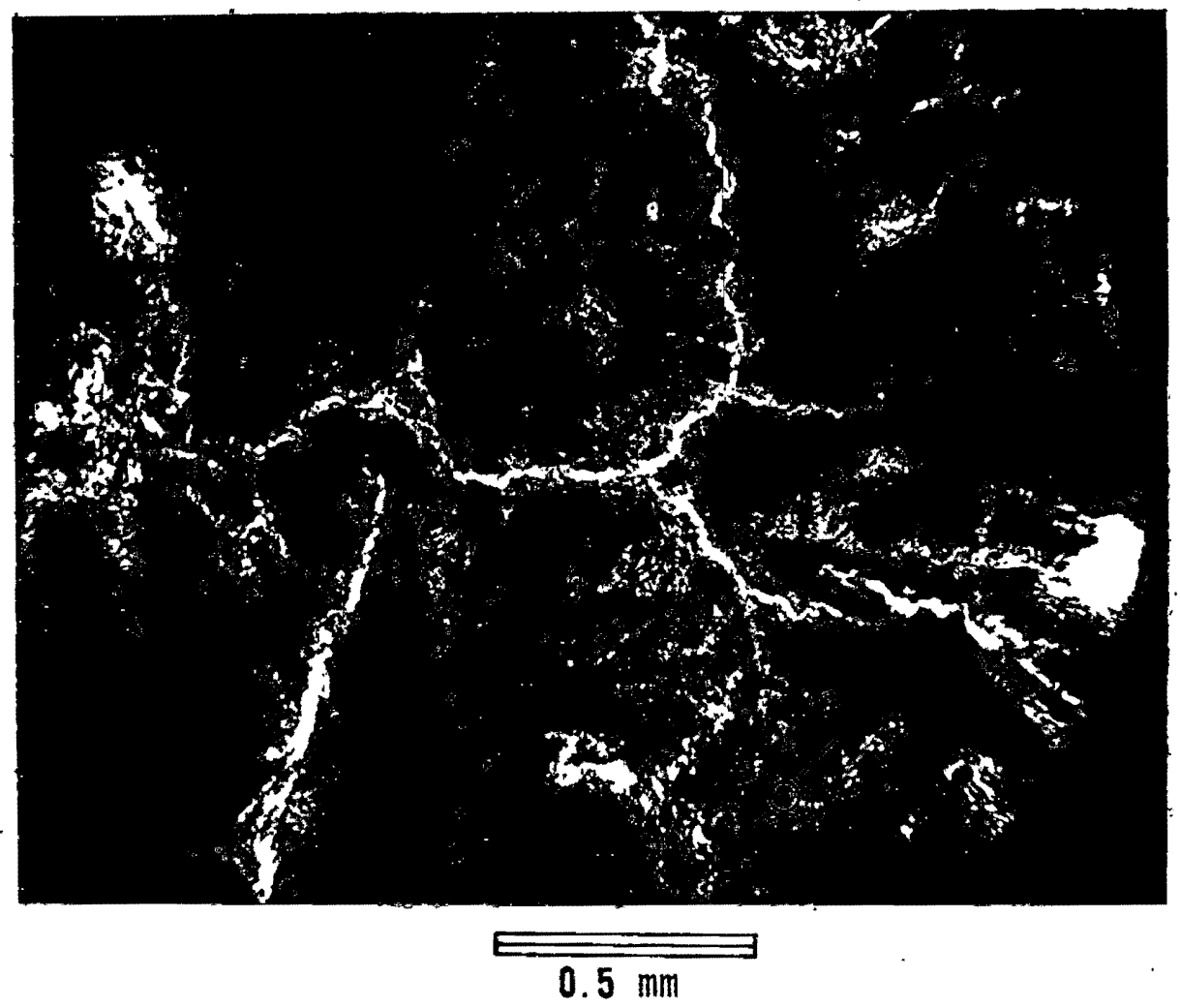

Figure 23. Photomicrograph, cross polarizers, showing the amorphous nature of the ferruginous bauxite zone. Wahkiakum County profile B (S-822). Note unweathered opaques. See text for discussion. 


\section{GEOCHEMISTRY OF THREE FERRUGINOUS BAUXITE PROFILES}

\section{PRESENTATION OF DATA}

The concentration of four major oxides and ten trace elements were determined from a suite of specimens in three ferruginous bauxite profiles using instrumental neutron activation (INAA) and wet chemical methods. A total of twenty-nine samples were analyzed for abundances of $\mathrm{Al}_{2} \mathrm{O}_{3}, \mathrm{SiO}_{2}, \mathrm{Fe}_{2} \mathrm{O}_{3}, \mathrm{TiO}_{2}, \mathrm{Na}, \mathrm{Sc}, \mathrm{Hf}, \mathrm{Cr}, \mathrm{Co}, \mathrm{La}, \mathrm{Sm}, \mathrm{Yb}, \mathrm{Iu}$, and Th. Tables $\mathrm{V}$ a-d list the elemental abundances and calculated errors determined in the selected samples from each profile and from related samples. Most samples studied for their mineralogical composition were used in conjunction with the geochemical analysis.

\section{METHODS OF INTERPRETING DATA}

A literature study reveals that two approaches are generally used to illustrate the elemental behavior during rock weathering. The first approach involves a comparison of elemental constituents in an unaltered rock to the elemental constituents in any soil horizon. Workers who have used this type of approach are Reiche (1943, 1950), Short (1961), Gordon and Murata (1952), Butler (1953), Wells (1960), Dennen and Anderson (1962), Goldrich (1938), and Tiller (1958). The second approach compares the element constituents in surface waters to the chemical composition of the rock in the drainage area. Students of this approach include Smyth (1913) and Polynov (1937). 
OXIDES AND ELEMENTAL ABUNDANCES OF A SUITE OF SAMPLES FROM BASALTIC CORESTONE PROFILE

(In ppm, unless specified)

\begin{tabular}{|c|c|c|c|c|c|c|}
\hline & & $\underline{S-200 \dot{A}}$ & $\begin{array}{l}S-200 \mathrm{C} \\
\mathrm{S}-200 \mathrm{~B} \\
\end{array}$ & $\underline{S-201}$ & $\underline{S-202}$ & $\underline{S-203}$ \\
\hline $\mathrm{Al}_{2} \mathrm{O}_{3}$ & (\%) & n.d. ${ }^{1}$ & n.d. & 19.9 & 14.72 & 15.11 \\
\hline $\mathrm{SiO}_{2}$ & $(\%)$ & n.d. & n.d. & 45.9 & 50.2 & 49.2 \\
\hline $\mathrm{Fe}_{2} \mathrm{O}_{3}$ & (क) & n.d. & n.d. & 24.1 & 23.1 & 25.7 \\
\hline $\mathrm{TiO}_{2}$ & (क) & n.d. & n.d. & 4.50 & 4.55 & 4.20 \\
\hline Lu & & $0.56 \pm 0.13$ & $0.90 \pm 0.15$ & $1.16 \pm 0.17$ & $1.8 \pm 0.2$. & n.d. \\
\hline Th & & $5.9 \pm 1.1$ & $7.0 \pm 1.1$ & $5.0 \pm 1.2$ & $6.6 \pm 1.2$ & n.d. \\
\hline $\mathrm{Sm}$ & & $6.4 \pm 0.2$ & $8.8 \pm 0.2$ & $13.4 \pm 0.3$ & $29.7 \pm 0.6$ & $31.3 \pm 0.7$ \\
\hline $\mathrm{Cr}$ & & $49 \pm 7$ & $54 \pm 8$ & $67 \pm 8$ & $69 \pm 8$ & n.d. \\
\hline $\mathrm{Hf}$ & & $5.4 \pm 0.9$ & $3.1 \pm 0.9$ & $3.1 \pm 1.0$ & $3.3 \pm 1.0$ & n.d. \\
\hline $\mathrm{Yb}$ & & $6.3 \pm 1.0$ & $6.7 \pm 1.0$ & $6.5 \pm 1.1$ & $14.0 \pm 1.5$ & $9.45 \pm 0.12$ \\
\hline Sc & & $34.4 \pm 0.4$ & $39.4 \pm 0.4$ & $38.6 \pm 0.4$ & $39.7 \pm 0.4$ & $40.3 \pm 0.6$ \\
\hline Co & & $86 \pm 3$ & $59 \pm 2$ & $48 \pm 2$ & $75 \pm 3$ & $45 \pm 3$ \\
\hline $\mathrm{Na}$ & (\%) & $1.97 \pm 0.02$ & $1.95 \pm 0.02$ & $1.15 \pm 0.02$ & $1.23 \pm 0.02$ & $1.24 \pm 0.02$ \\
\hline \multirow[t]{2}{*}{ La } & & $19.6 \pm 1.3$ & $30 \pm 1.9$ & $47 \pm 2$ & $91 \pm 4$ & $98 \pm 4$ \\
\hline & & $\underline{s-204}$ & S-205 & $\underline{s-206}$ & $\mathrm{~s}-207$ & \\
\hline $\mathrm{Al}_{2} \mathrm{O}_{3}$ & (क) & 26.0 & 26.3 & 26.5 & 30.9 & \\
\hline $\mathrm{SiO}_{2}$ & $(\mathscr{6})$ & 41.2 & 34.8 & 34.5 & 18.4 & . \\
\hline $\mathrm{Fe}_{2} \mathrm{O}_{3}$ & (क) & 22.0 & 23.9 & 23.9 & 30.1 & \\
\hline $\mathrm{TiO}_{2}$ & $(x)$ & 3.65 & 4.60 & 4.25 & 5.60 & \\
\hline Iu & & $0.90 \pm 0.16$ & $1.30 \pm 0.19$ & $1.1 \pm 0.2$ & $0.4 \pm 0.2$ & \\
\hline $\operatorname{Th}$ & & $7.2 \pm 1.2$ & $4.9 \pm 1.3$ & $5.7 \pm 1.6$ & $6.7 \pm 1.8$ & \\
\hline $\mathrm{Sm}$ & & $20.9 \pm 0.6$ & n.d. & $21.3 \pm 0.4$ & $5.76 \pm 0.12$ & 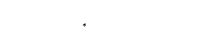 \\
\hline $\mathrm{Cr}$ & & $74 \pm 8$ & $63 \pm 9$ & $68 \pm 11$ & $102 \pm 13$ & . \\
\hline $\mathrm{Bf}$ & & $4.7 \pm 1.0$ & $6.1 \pm 1.1$ & $7.6 \pm 1.3$ & $7.4 \pm 1.6$ & \\
\hline $\mathrm{Yb}$ & & $9.1 \pm 1.2$ & n.d. & $8 \pm 0.9$ & $2.8 \pm 0.6$ & \\
\hline Sc & & $47 \pm 1$ & $57 \pm 1$ & $47 \pm 1$ & $65 \pm 1$ & \\
\hline Co & & $52 \pm 2$ & $74 \pm 3$ & $59 \pm 2$ & $88 \pm 3$ & \\
\hline $\mathrm{Na}$ & (\%) & $0.69 \pm 0.01$ & n.d. & $0.41 \pm 0.01$ & $0.11 \pm 0.00$ & \\
\hline La & & $66.2 \pm 3.0$ & n.d. & $52 \pm 2$ & $11.7 \pm 0.5$ & \\
\hline
\end{tabular}

${ }^{2}$ memental abundance not determined. 
OXIDES AND ELEMENTAL ABUNDANCES OF A SUITE OF SAMPLES FROM WAFKIAKUM COUNTY PROFILE A (In ppm, unless specified)

\begin{tabular}{|c|c|c|c|c|c|c|}
\hline & & $\underline{S-888}$ & $\mathrm{~S}-888 \mathrm{~A}$ & $\mathrm{~s}-891$. & $\underline{s-891 A}$ & $\underline{s-893}$ \\
\hline $\mathrm{Al}_{2} \mathrm{O}_{3}$ & $(\%)$ & 38.17 & n.d. ${ }^{1}$ & 39.34 & n.d. & 35.0 \\
\hline $\mathrm{SiO}_{2}$ & $(\%)$ & $\begin{array}{l}8.5 i \\
(6.09)^{2}\end{array}$ & n.d. & 5.6 & n.d. & 17.84 \\
\hline $\mathrm{Fe}_{2} \mathrm{O}_{3}$ & $(\%)$ & 28.95 & n.d. & 26.2 & n.a. & 23.2 \\
\hline $\mathrm{TiO}_{2}$ & (\%) & 3.60 & n.d. & 5.82 & n.d. & 5.08 \\
\hline Lu & & $0.51 \pm 0.14$ & $0.73 \pm 0.14$ & $0.51 \pm 0.15$ & $0.015 \pm 0.06$ & $0.25 \pm 0.15$ \\
\hline Th & & $33 \pm 1$ & $43.2 \pm 2.1$ & $27.8 \pm 3.7$ & $4.9 \pm 0.6$ & $18 \pm 1.5$ \\
\hline Sm & & $1.52 \pm 0.64$ & $1.20 \pm 0.03$ & $1.06 \pm 0.03$ & $0.15 \pm 0.00$ & $1.85 \pm 0.04$ \\
\hline $\mathrm{Cr}$ & & $238 \pm 8$ & $424 \pm 10$ & $330 \pm 10$ & $86 \pm 5$ & $265 \pm 10$ \\
\hline Hf & & $17.4 \pm 1.2$ & $1.69 \pm 0.83$ & $18.78 \pm 1.4$ & $3.5 \pm 0.5$ & $12.7 \pm 1.3$ \\
\hline $\mathbf{r b}$ & & $2.16 \pm 0.39$ & $1.94 \pm 0.43$ & $1.18 \pm 0.40$ & $0.06 \pm 0.19$ & $0.24 \pm 0.41$ \\
\hline Se & & $24.2 \pm 0.3$ & $21.3 \pm 0.2$ & $59 \pm 0.0$ & $11.3 \pm 0.0$ & $63 \pm 1$ \\
\hline Co & & $3.9 \pm 0.6$ & $3.6 \pm 0.5$ & $5.9 \pm 0.8$ & $1.97 \pm 0.29$ & $12.9 \pm 0.9$ \\
\hline $\mathrm{Na}$ & (\%) & $0.071 \pm 0.002$ & $0.033 \pm 0.009$ & n.a. & n.d. & $0.053 \pm 0.004$ \\
\hline \multirow[t]{2}{*}{ Ia } & & $4.3 \pm 0.2$ & $5.7 \pm 0.3$ & $5.3 \pm 0.2$ & $0.56 \pm 0.05$ & $5.8 \pm 0.3$ \\
\hline & & $\underline{s-895}$ & $\underline{s-897}$ & $\underline{s-899}$ & $\underline{s-954}$ & $\underline{S-954 A}$ \\
\hline $\mathrm{Al}_{2} \mathrm{O}_{3}$ & $(\%)$ & 31.26 & 30.5 & 38.8 & 26.0 & n.d. \\
\hline $\mathrm{SiO}_{2}$ & $(\%)$ & 24.5 & 24.6 & 16.2 & 30.3 & n.d. \\
\hline $\mathrm{Fe}_{2} \mathrm{O}_{3}$ & $(\not)$ & 24.0 & 24.6 & 22.0 & 21.62 & n.d. \\
\hline $\mathrm{TiO}_{2}$ & $(\mathscr{q})$ & 3.90 & 3.85 & 2.94 & 3.60 & n.d. \\
\hline Lu & & $0.64 \pm 0.15$ & $0.25 \pm 0.14$ & $0.22 \pm 0.14$ & $1.03 \pm 0.22$ & $0.83 \pm 0.14$ \\
\hline $\mathbf{T h}$ & & $11.3 \pm 1.4$ & $7.6 \pm 1.3$ & $7.5 \pm 1.3$ & $7.8 \pm 1.5$ & $2.6 \pm 1.1$ \\
\hline Sm & & $1.98 \pm 0.04$ & $2.0 \pm 0.1$ & $1.39 \pm 0.03$ & $1.67 \pm 0.39$ & $7.5 \pm 0.3$ \\
\hline $\mathrm{Cr}$ & & $245 \pm 10$ & $207 \pm 10$ & $216 \pm 10$ & $250 \pm 11$ & $107 \pm ?$ \\
\hline $\mathrm{HF}$ & & $9.2 \pm 1.2$ & $6.9 \pm 1.2$ & $8.0 \pm 1.2$ & $6.6 \pm 1.2$ & $1.93 \pm 0.89$ \\
\hline $\mathbf{Y b}$ & & $1.57 \pm 0.40$ & $1.28 \pm 0.40$ & $1.14 \pm 0.38$ & $7.7 \pm 1.3$ & $6.2 \pm 0.9$ \\
\hline Sc & & $59 \pm 1$ & $60 \pm 1$ & $61 \pm 1$ & $66 \pm 1$ & $38 \pm 0.4$ \\
\hline Co & & $20.5 \pm 1.5$ & $29.5 \pm 1.4$ & $96 \pm 3$ & $67 \pm 3$ & $41.6 \pm 1.7$ \\
\hline $\mathrm{Na}$ & (\%) & $0.10 \pm 0.00$ & $.085 \pm 0.004$ & n.d. & $0.134 \pm 0.006$ & n.d. \\
\hline La & & $5.4 \pm 0.3$ & $6.3 \pm 0.3$ & $3.0 \pm 0.2$ & $60 \pm 3$ & $24.0 \pm 1.4$ \\
\hline
\end{tabular}


TABIE V-c

OXIDES AND ELEMENTAL ABUNDANCES OF A SUTTE OF SAMPLES FROM WAHKIAKUM COUNTY PROFILE B

(In ppm, unless specified)

$\underline{S-812}$

$\underline{5-815}$

s-822.

$\underline{S-824}$

$\underline{S-840}$

$\begin{array}{lll}\mathrm{Al}_{2} \mathrm{O}_{3}(\%) & 30.8 \\ \mathrm{SiO}_{2}(\%) & 31.4 \\ \mathrm{Fe}_{2} \mathrm{O}_{3}(\%) & 20.39 \\ \mathrm{TiO}_{2}(\%) & 3.28 \\ \mathrm{Lu} & 0.22 \pm 0.14 \\ \mathrm{Th} & 9.1 \pm 1.4 \\ \mathrm{Sm} & & 1.90 \pm 0.04 \\ \mathrm{Cr} & & 157 \pm 9 \\ \mathrm{Hf} & & 8.2 \pm 1.1 \\ \mathrm{Yb} & & 1.41 \pm 0.38 \\ \mathrm{Sc} & & 57 \pm 1 \\ \mathrm{Co} & & 9.9 \pm 0.8 \\ \mathrm{Na} & (\%) & 0.098 \pm 0.003 \\ \mathrm{Ia} & & 6.3 \pm 0.3\end{array}$

28.4

.34 .1

19.78

33.3

37.7

3.72

12.23

3.28

$0.51 \pm 0.13$

$0.46 \pm 0.14$

$7.0 \pm 1.2$

$6.9 \pm 1.2$

$1.52 \pm 0.04$

$2.1 \pm 0.0$

$183 \pm 9$

$168 \pm 9$

$9.2 \pm 1.1$

$9.5 \pm 1.1$

$0.90 \pm 0.35$

$2 \pm 0.4$

$52.4 \pm 0.5$

$54.3 \pm 0.5$

$9.5 \pm 0.9$

$117 \pm 4$

$0.12 \pm 0.003$

$$
\text { n.d. } 1
$$

$8.04 \pm 0.34$

$9.8 \pm 0.4$

28.4

31.6

33.1

38.4

20.4

11.81

3.70

3.90

$0.38 \pm 0.16$

$0.35 \pm 0.14$

No Peak

$8.8 \pm 1.3$

$3.2 \pm 0.1$

$1.43 \pm 0.03$

No Peak

$213 \pm 10$

No Peak

$6.6 \pm 1.2$

$1.61 \pm 0.43$

$1.11 \pm 0.38$

$83 \pm 1$

$78 \pm 1$

$283 \pm 9$

$12.1 \pm 1.0$

$0.12 \pm 0.00$

$0.14 \pm 0.00$

\section{$s-860$}

$\mathrm{s}-870$

\section{$\underline{S-880}$}

\begin{tabular}{|c|c|c|c|c|}
\hline $\mathrm{Al}_{2} \mathrm{O}_{3}$ & (\%) & 26.6 & 26.5 & 22.71 \\
\hline $\mathrm{SiO}_{2}$ & (\%) & 56.1 & 40.0 & 44.4 \\
\hline $\mathrm{Fe}_{2} \mathrm{O}_{3}$ & $(\phi)$ & 6.32 & 18.55 & 18.76 \\
\hline $\mathrm{TiO}_{2}$ & (\%) & 1.29 & 3.00 & 2.75 \\
\hline Lu & & $1.67 \pm 0.20^{\circ}$ & $0.99 \pm 0.16$ & $1.36 \pm 0.10$ \\
\hline Th & & $13.5 \pm 1.1$ & $6.6 \pm 1.2$ & $2.8 \pm 1.3$ \\
\hline$S m$ & & $23.0 \pm 0.5$ & $13.3 \pm 0.3$ & $12.3 \pm 0.3$ \\
\hline $\mathrm{Cr}$ & & $95 \pm 7$ & $192 \pm 9$ & $198 \pm 10$ \\
\hline Hf & & $7.3 \pm 0.9$ & $5.5 \pm 1.0$ & $6.4 \pm 1.1$ \\
\hline $\mathrm{Yb}$ & & $12.4 \pm 1.3$ & $6.7 \pm 0.7$ & $8.3 \pm 0.8$ \\
\hline Sc & & $26.7 \pm 0.3$ & $48.2 \pm 0.5$ & $56 \pm 1$ \\
\hline Co & & $17.0 \pm 1.0$ & $82 \pm 3$ & $71 \pm 3$ \\
\hline $\mathrm{Na}$ & (\%) & $0.068 \pm 0.008$ & $0.20 \pm 0.13$ & n.d. \\
\hline$\pi$ & & $77 \pm 4$ & $40.1 \pm 1.5$ & $27.9 \pm 1.1$ \\
\hline
\end{tabular}

$1_{\text {Elemental abundance not determined. }}$ 
TABLE V-d

ETEMENTAL ABUNDANCES OF COLUMBIA RIVER BASALT COLLECTED IN WAHKIAKUM COUNTY, WASHINGTON

(IN PPM, UNLESS SPECIFIED)

$\begin{array}{lll} & \text { RLJ-2-71 } & \text { RLJ }-3-71 \\ \mathrm{Lu} & 0.29 \pm 0.12 & 0.54 \pm 0.13 \\ \mathrm{Th} & 3.4 \pm 1.0 & 3.6 \pm 0.9 \\ \mathrm{Sm} & 3.8 \pm 0.1 & 0.80 \pm 0.02 \\ \mathrm{Cr} & 116 \pm 8 & 227 \pm 8 \\ \mathrm{Hf} & 5.0 \pm 0.9 & 4.3 \pm 0.8 \\ \mathrm{Yb} & \mathrm{n} . \mathrm{d} .1 & 0.28 \pm 0.00 \\ \mathrm{Sc} & 38.4 \pm 0.3 & 35.2 \pm 0.4 \\ \mathrm{Co} & 41.2 \pm 1.7 & 8.0 \pm 0.7 \\ \mathrm{Na}(\%) & 1.74 \pm 0.00 & 1.77 \pm 0.206 \\ \mathrm{La} & 20.8 \pm 2.6 & \mathrm{n} . \mathrm{d} .\end{array}$

$I_{\text {Elemental abundance not determined. }}$ 
For this study, the first approach will be utilized to illustrate the relative behavior of cations in the ferruginous bauxite profiles by comparing concentration values in the weathered rock to the unaltered rock. A brief review of a few methods are summarized below:

(1) The concentration ratio method (Gordon and Murata, 1952) compares the constituents in any weathered horizon to the parent rock. The mathematical expression for concentration ratio is:

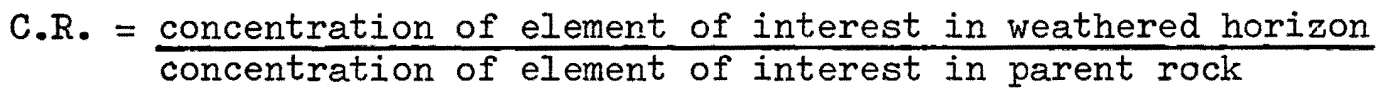

A C.R. value greater than one implies an enrichment; whereas a value less than one implies a depletion of a constituent.

(2) Reiche (1950) proposed a weathering potential index (W.P.I.) to indicate the degree of weathering in terms of mineral stability. Weathering potential index is defined as:

$$
\frac{\text { mols. }\left(\mathrm{K}_{2} \mathrm{O}+\mathrm{Na}_{2} \mathrm{O}+\mathrm{CaO}+\mathrm{MgO}-\mathrm{H}_{2} \mathrm{O}\right)}{\text { mols. }\left(\mathrm{SiO}_{2}+\mathrm{Al}_{2} \mathrm{O}_{3}+\mathrm{Fe}_{2} \mathrm{O}_{3}+\mathrm{CaO}+\mathrm{MgO}+\mathrm{Na}_{2} \mathrm{O}+\mathrm{H}_{2} \mathrm{O}\right)} \times 100
$$

(3) Short (1961) modified Reiche's weathering potential index by dividing the W.P.I. for any weathered horizon into the W.P.I. for the parent rock. The quotient is termed weathering index (W.I.). The W.I. values range from zero to one; a value of zero indicates an intensively weathered rock and a value of one implies a slightly weathered rock. Neither method can be applied in this study, because several of the elements necessary to compute Reiche's index were not determined.

(4) Goldrich (1938) and Pettijohn (1957) devised an empirical method to demonstate the relative losses and gains of elements if 
$\mathrm{Al}_{2} \mathrm{O}_{3}$ is assumed to remain constant during rock weathering. The percentage loss or gain of any constituent in a weathered horizon relative to $\mathrm{Al}_{2} \mathrm{O}_{3}$ is found as follows:

a. Let $E=$ the abundance of an element in the weathered rock and $\mathrm{Z}=$ the abundance of the same element in the parent rock.

b. Calculate correction factor (K):

$$
\mathrm{K}=\frac{\mathrm{Al}_{2} \mathrm{O}_{3} \text { content (\%) in parent rock }}{\mathrm{AI}_{2} \mathrm{O}_{3} \text { content (\%) in any weathered horizon }}
$$

c. Calculate percentage net loss or gain, expressed as:

$$
\frac{\mathrm{KE}-\mathrm{Z}}{\mathrm{Z}} \times 100
$$

The purpose of the correction factor is to compensate for volumetric changes and to reduce the effect of the relative changes. A negative value means that an element is depleted relative to alumina and a positive value means that an element is enriched relative to alumina in a weathered horizon.

For this study, the concentration ratio (Gordon and Murata, 1952) was chosen to illustrate the relative mobility of elements in the three ferruginous bauxite profiles, because geochemical data can be easily utilized by this method.

Assumptions necessary to compute the concentration ratio (C.R.) values are:

(1) Alumina is assumed to be constant during the course of weathering.

(2) The computed relative mobility values for profile A and B are based on an unweathered basalt flow, specimen RLJ-2-71, which crops out near the two profiles. 
(3) Major elements, $\mathrm{SiO}_{2}, \mathrm{Al}_{2} \mathrm{O}_{3}, \mathrm{Fe}_{2} \mathrm{O}_{3}$, and $\mathrm{TiO}_{2}$, were not analyzed in the parent rocks; therefore, the oxide abundances of a Columbia River basalt specimen in Wahkiakum County, Washington were substituted in Iieu thereof (Iivingston, 1966, p. 32). The FeO and $\mathrm{Fe}_{2} \mathrm{O}_{3}$ of this specimen is computed to total $\mathrm{Fe}_{2} \mathrm{O}_{3}$

RELATIVE MOBILITY OF INDIVIDUAL EIEMENTS IN THE PROFIIES

Table VI a-c list the concentration ratios of each profile. In addition, Figure 24 through Figure 26 graphically depicts the concentration ratio trends. Whenever possible the relative mobility of individual elements will be related to the mineralogy and weathered zones that have previously been discussed under "Mineralogy."

Basaltic Corestone Profile.

\section{Major elements}

Alumina $\left(\mathrm{Al}_{2} \mathrm{O}_{3}\right)$, Ferric iron oxide $\left(\mathrm{Fe}_{2} \mathrm{O}_{3}\right)$, Titanium oxide $\left(\mathrm{TiO}_{2}\right)$ These elements are enriched relative to the parent rock in all the weathered zones (Figure 24). $\mathrm{TiO}_{2}$ and $\mathrm{Fe}_{2} \mathrm{O}_{3}$ display a stronger enrichment than $\mathrm{Al}_{2} \mathrm{O}_{3}$, respectively. The greatest concentration of these oxides is in the ferruginous bauxite zone. During weathering these oxides are thought to be precipitated by hydrolysis as authigenic minerals, e.g. limonite (Mason, 1966, p. 163). Some oxides tend to remain in the unaltered crystalline structure, such as $\mathrm{TiO}_{2}$ in ilmenite.

Silica $\left(\mathrm{SiO}_{2}\right)$ and Sodium $(\mathrm{Na})-\mathrm{SiO}_{2}$ and $\mathrm{Na}$ are depleted relative to the parent rock (Figure 24); sodium always shows the largest Ioss. 
TABLE VI-a

BASALTIC CORESTONE PROFILE

CONCENTRATION RATIOS

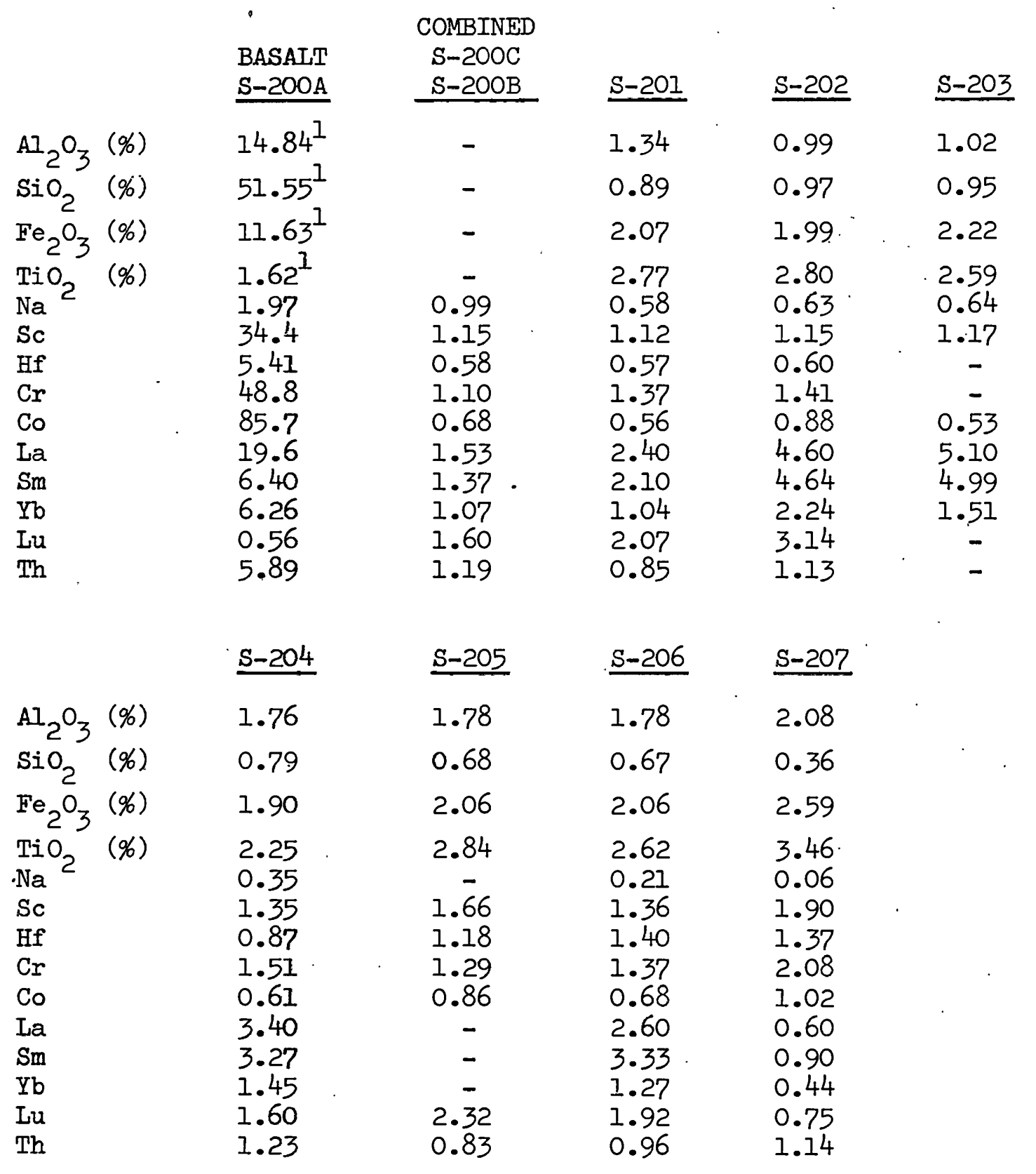

$I_{\text {These oxides were determined by Livingston (1966, p. 39) from }}$ a basalt specimen in Wahkiakum County, Washington. 
TABLE VI-b

WAHKIAKUM COUNTY PROFILE A CONCENTRATION RATIOS

\section{BASALT}

$\underline{\text { (RLJ-2-71) }} \quad \underline{\text { S-954A }} \quad \underline{S-954} \cdot \underline{S-899} \quad \underline{S-897} \quad \underline{S-895}$

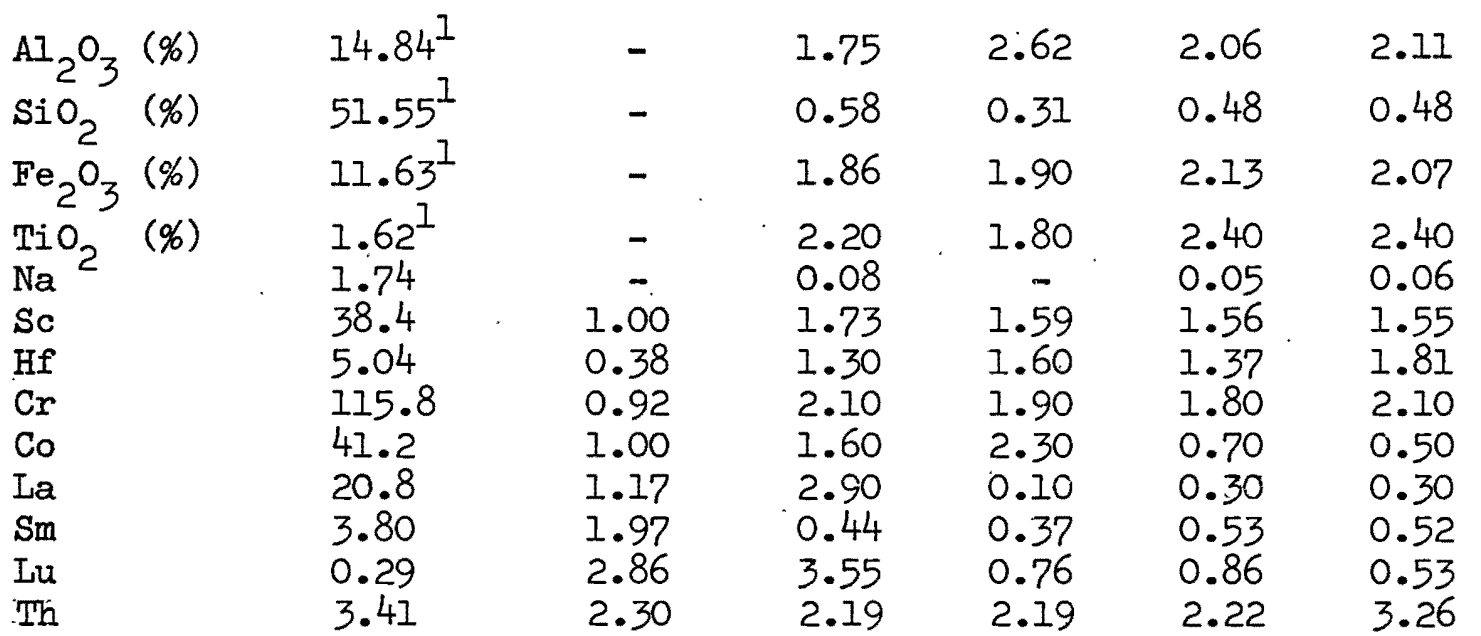

$\underline{\mathrm{S}-893} \quad \underline{\mathrm{S}-891 \mathrm{~A}} \quad \underline{\mathrm{S}-891} \quad \underline{\mathrm{S}-888 \mathrm{~A}} \quad \underline{\mathrm{S}-888}$

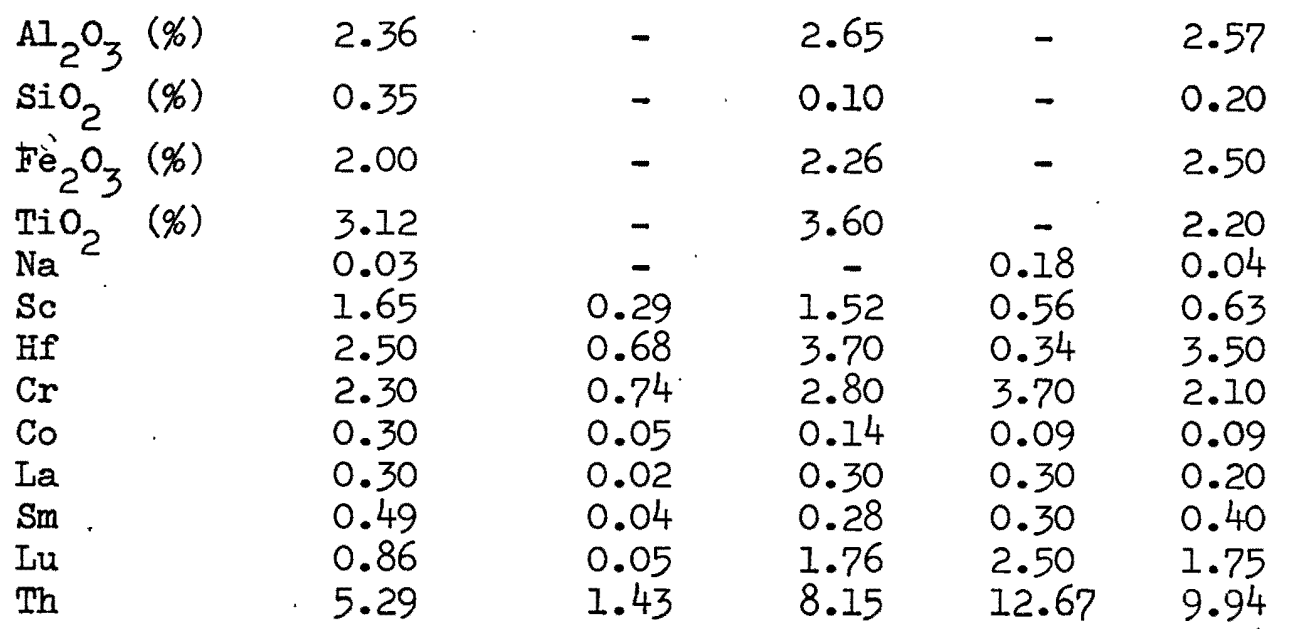

Note: Yo was not determined in the parent rock (RLJ-2-7I) and therefore C.R. values were not computed.

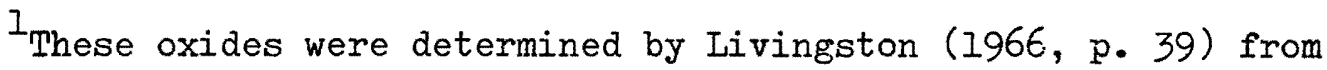
a basalt specimen in Wahkiakum County, Washington. 
TABLE VI-c

WAHKIAKUM COUNTY PROFIIE B CONCENTRATION RATIOS

\begin{tabular}{|c|c|c|c|}
\hline & $\begin{array}{c}\text { BASAIT } \\
(\text { RIJ }-2-71)\end{array}$ & $\underline{S-880}$ & $s-824$ \\
\hline $\mathrm{Al}_{2} \mathrm{O}_{3}(\%)$ & $14.84^{1}$ & 1.54 & 1.92 \\
\hline $\mathrm{SiO}_{2}(\%)$ & $51.55^{1}$ & 0.86 & 0.64 \\
\hline $\mathrm{Fe}_{2} \mathrm{O}_{3}(\%)$ & $11.63^{1}$ & 1.62 & 1.75 \\
\hline $\mathrm{TiO}_{2} \quad(\%)$ & $1.62^{1}$ & 1.70 & 2.28 \\
\hline Sc & $\begin{array}{l}1.74 \\
38.4\end{array}$ & $1 . \overline{46}$ & $\begin{array}{l}0.07 \\
2.16\end{array}$ \\
\hline Hf & 5.04 & 1.27 & - \\
\hline $\begin{array}{l}\mathrm{Cr} \\
\mathrm{Co}\end{array}$ & 115.8 & 1.71 & - \\
\hline $\begin{array}{l}\text { Co } \\
\text { La }\end{array}$ & 41.2 & 1.71 & 6.86 \\
\hline $\begin{array}{l}\text { La } \\
\mathrm{Sm}\end{array}$ & 20.8 & 1.34 & 0.49 \\
\hline $\begin{array}{l}\text { Sm } \\
\text { Lu }\end{array}$ & 3.80 & 3.24 & 0.85 \\
\hline $\begin{array}{l}\text { Lu } \\
\text { Th }\end{array}$ & $\begin{array}{l}0.29 \\
3.47\end{array}$ & $\begin{array}{l}4.69 \\
0.82\end{array}$ & 1.31 \\
\hline & & & \\
\hline & $\underline{S-822}$ & $\underline{s-815}$ & $\underline{S-812}$ \\
\hline $\mathrm{Al}_{2} \mathrm{O}_{3}(\%)$ & 2.25 & 1.92 & 2.08 \\
\hline $\mathrm{SiO}_{2}(\%)$ & 0.73 & 0.66 & 0.61 \\
\hline $\mathrm{Fe}_{2} \mathrm{O}_{3}(\%)$ & 1.05 & 1.71 & 1.76 \\
\hline $\left.\mathrm{TiO}_{2} \quad \%\right)$ & 2.02 & 2.30 & 2.02 \\
\hline & - & 0.07 & 0.06 \\
\hline Sc & 1.41 & 1.37 & 1.48 \\
\hline $\mathrm{Hf}$ & 1.88 & 1.82 & 1.62 \\
\hline $\mathrm{Cr}$ & 1.45 & 1.58 & 1.36 \\
\hline Co & 2.84 & 0.23 & 0.24 \\
\hline $\mathrm{La}$ & 0.47 & 0.39 & 0.30 \\
\hline $\mathrm{Sm}$ & 0.55 & 0.40 & 0.50 \\
\hline $\mathrm{Lu}$ & 1.59 & 1.76 & 0.76 \\
\hline Th & 2.03 & 2.06 & 2.65 \\
\hline
\end{tabular}

Note: Yb was not determined in the parent rock (RIJ-2-7I) and therefore C.R. values were not computed.

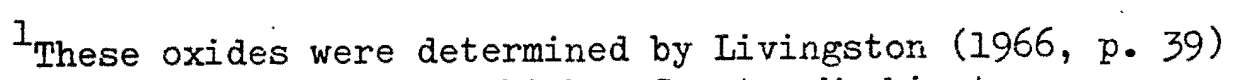
from a basalt specimen in Wahkiakum County, Washington. 


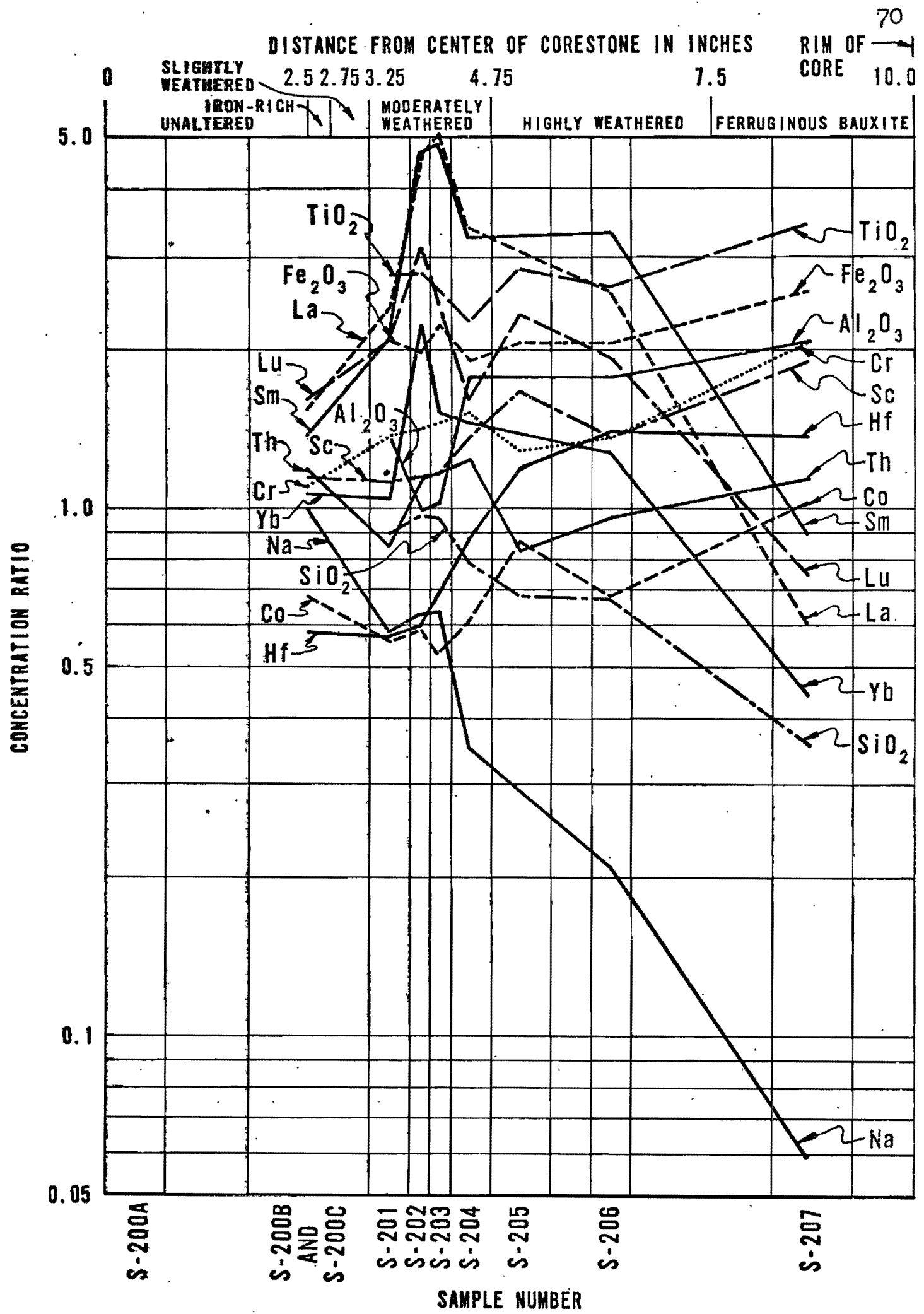

Figure 24. Plot of concentration ratios. Basaltic corestone profile. 


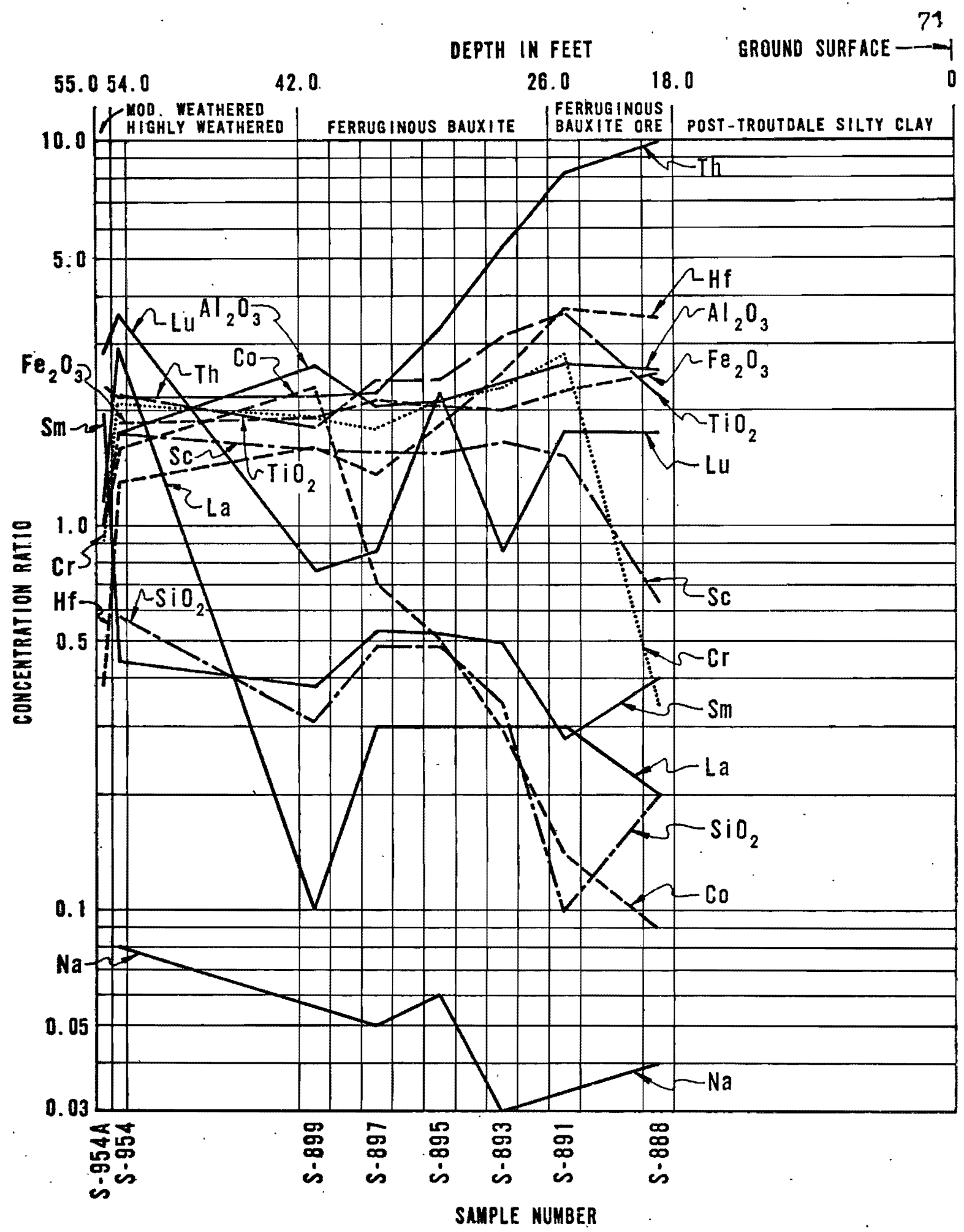

Figure 25. Plot of concentration ratios. Wahkiakum County profile A. 


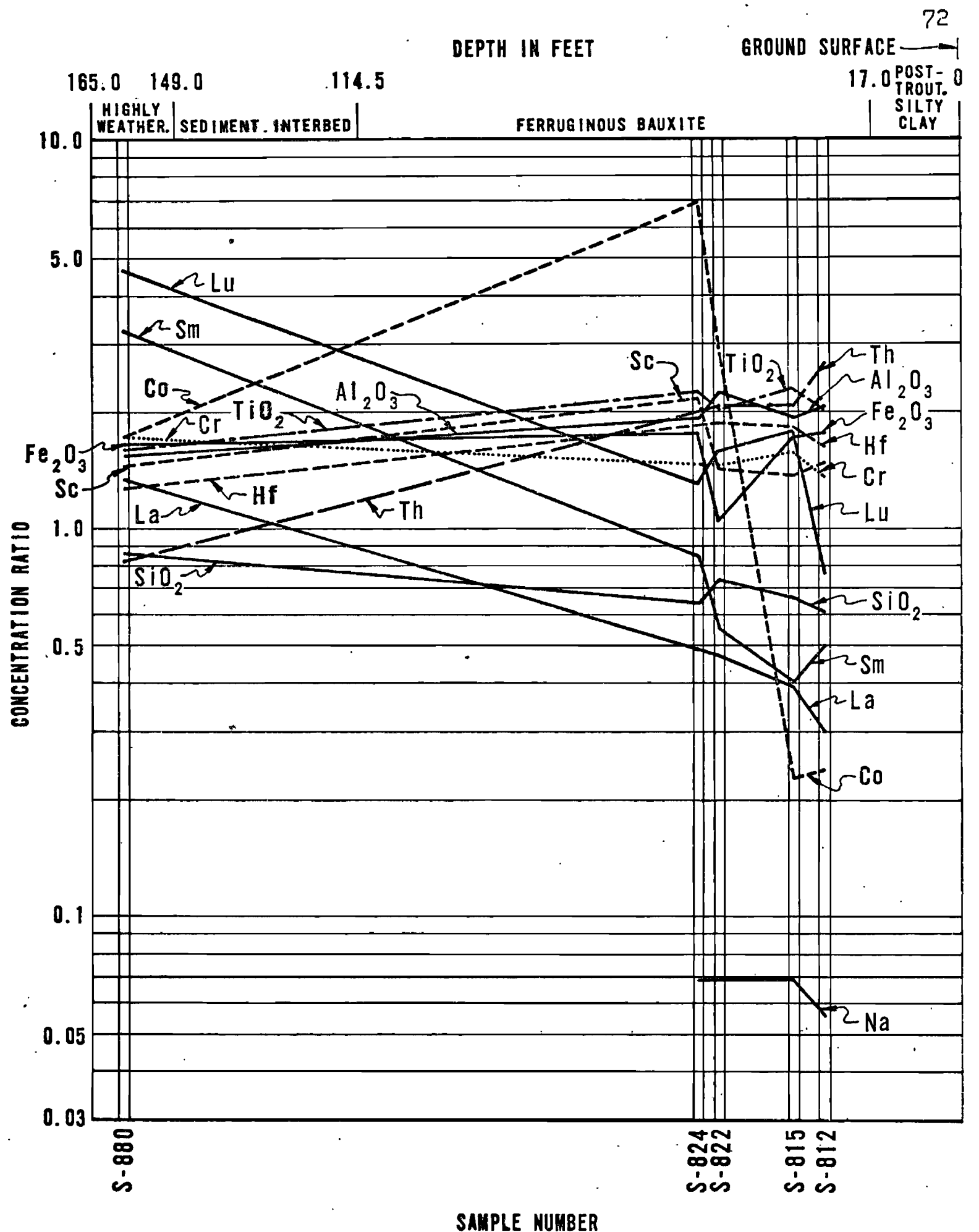

Figure 26. Plot of concentration ratios. Wahkiakum County profile B. 
The greatest depletion of $\mathrm{Na}$ and $\mathrm{SiO}_{2}$ occurs in the ferruginous bauxite zone (S-207). These elements are removed when glass and feldspar constituents deteriorate under the influence of weathering (Figure 14).

Trace elements

Scandium (Sc) - According to Taylor (1966), scandium commonly substitutes for $\mathrm{Ti}^{+4}$ and $\mathrm{Zr}^{+4}$ in pyroxene minerals during magmatic crystallization. In the weathering profile, $S c$ is enriched relative to the parent rock; it is strongly enriched in the ferruginous bauxite zone (s-207). Scandium in natural water is predicted to precipitate as hydrolysates (Mason, 1966, p. 3) and would be enriched in the weathered rock. The concentration ratios in specimen 207 , indicate such an enrichment.

Samarium ( $\mathrm{Sm}$ ) and Lanthanum ( $\mathrm{Ia}$ ) - The concentration ratio trends of Ia and Sm nearly parallel each other during the course of weathering as shown in Figure 24. In all samples, except S-207, these elements are enriched relative to the parent rock. Ia and $\mathrm{Sm}$ appear to be immobile until the intensity of weathering progresses to where they are released and are subsequently removed in solution.

Lutetium $(\mathrm{Iu})$ and Ytterbium $\left(\mathrm{Yb}_{\mathrm{b}}\right)$ - These rare earth elements roughly parallel the concentration ratio trends of $\mathrm{Sm}$ and $\mathrm{Ia}$. These elements are enriched in all weathered zones, except in the ferruginous bauxite section (most weathered), $\mathrm{Lu}$ and $\mathrm{Yb}$ are enriched relative to the parent rock, but are depleted in sample 207.

Hafnium (Hf) - Hf is depleted in the slightly weathered and 
moderately weathered zones, but enriched in the highly weathered and ferruginous bauxite zones (Figure 24).

Thorium (Th) - Concentration ratios of Th in relation to the weathering zones are erratic. In some zones it has been enriched while in others it has been depleted.

Chromium (Cr) - This element has been enriched in all samples (Figure 24). The general trend of chromium is a gradual enrichment upon weathering of the basalt.

Cobalt (Co) - In most cases, cobalt is depleted relative to the parent rock. Although the curve for cobalt is irregular, the apparent slope is to the right. This trend suggests a progressive enrichment of cobalt as the rock weathers.

Wahkiakum County Profile A

\section{Major elements}

Alumina $\left(\mathrm{Al}_{2} \mathrm{O}_{3}\right)$, Ferric iron oxides $\left(\mathrm{Fe}_{2} \mathrm{O}_{3}\right)$, Titanium oxide $\left(\mathrm{TiO}_{2}\right)$ In all weathered samples, $\mathrm{Al}_{2} \mathrm{O}_{3}, \mathrm{Fe}_{2} \mathrm{O}_{3}$, and $\mathrm{TiO}_{2}$, have increased relative to the parent rock; usually by a factor of two or three (Figure 25). The lower concentration ratio value for $\mathrm{TiO}_{2}$ in the ferruginous bauxite ore is probably attributed to a change in parent rock type. Concentration values in this profile resemble those in the basaltic corestone profile.

Silica $\left(\mathrm{SiO}_{2}\right)$ and Sodium (Na) - As expected, silica and sodium are depleted relative to the parent rock upon weathering (Figure 25). Sodium is depleted more than $\mathrm{SiO}_{2}$ in all weathered horizons. A lower concentration ratio in the pisolitic unit (ferruginous bauxite ore zone) 
is attributed to quartz grains which are embedded in the iron-rich pisolites and bauxite matrix (Figure 22).

\section{Trace elements}

Scandium (SC) - Gordon and Murata (1952) have shown that scandium is concentrated in bauxites and bauxitic clay samples from Arkansas. In profile A, Sc is also enriched relative to parent rock except in specimen 888 (Figure 25). The behavior of Sc in the pisolitic unit may be due to a different parent rock which originally had a lower scandium content.

Hafnium (Hf) - In the highly weathered zone hafnium is depleted relative to parent rock, but it is enriched in the ferruginous bauxite and ferruginous bauxite ore zone. A similar C.R. trend is shown in the basaltic corestone profile.

Samarium (Sm) and Lanthanum ( $\mathrm{La}$ ) - Both Sm and La are enriched near the parent rock, but are depleted in the more weathered zones. Both elements roughly parallel trends observed in the basaltic corestone. Lutetium ( $I u)$ and Ytterbium $(\mathrm{Yb})$ - Iu is depleted in the ferruginous bauxite section, but is enriched in the moderately and highly weathered zones and in the ore unit. Concentration ratios were not. computed for $\mathrm{Yb}$, but its abundances indicate a high concentration in the partly weathered rock and low concentrations in the lateritic material.

Thorium (Th) - Thorium is increased relative to the parent rock and the strongest enrichment occurs in the ferruginous bauxite ore zone. Hafnium roughly parallels the Th concentration ratio trends. 
Chromium (Cr) - During magmatic crystallization, $\mathrm{Cr}^{+3}$, may substitute for $\mathrm{Fe}^{+3}$ in oxides (Taylor, 1966). In profile A, the weathered rock is usually enriched in chromium, particularly in the iron-rich pisolites. Possibly chromium substitutes for $\mathrm{Fe}^{+3}$ in iron hydrates, e.g. limonite.

Cobalt (Co) - Geochemical studies of decomposed hornblende gabbro by Butler (1953) shows that Co is enhanced. This profile indicates an enrichment of Co only in. the partly altered rock. In the more weathered rock, Co is depleted and strongly depleted in the ore material.

Wahkiakum County Profile $B^{I}$

Major elements

Alumina $\left(\mathrm{Al}_{2} \mathrm{O}_{3}\right)$, Ferric iron oxides $\left(\mathrm{Fe}_{2} \mathrm{O}_{3}\right)$, Titanium oxide $\left(\mathrm{TiO}_{2}\right)$ Relative to the parent rock $\mathrm{Al}_{2} \mathrm{O}_{3}, \mathrm{Fe}_{2} \mathrm{O}_{3}$, and $\mathrm{TiO}_{2}$ are enriched. Silica and sodium are depleted (Figure 26). Concentration ratio values of these elements compare with those in profile $A$ and the basaltic corestone profile.

\section{Trace elements}

Scandium (Sc) and Hafnium (Hf) - Scandium and hafnium are enriched relative to the parent rock and roughly correlate with findings in the other profiles.

${ }^{I}$ g geochemical discussion on the sedimentary interbeds is omitted in this report. 
Samarium (Sm) and Lanthanum ( $\mathrm{La})$ - The concentration ratio trends (Figure 26) of La and Sm roughly parallel each other in profile B. This trend also was observed in the other profiles studied. In the highly weathered (S-880) zone, La and Sm are enriched relative to the parent rock.

Lutetium ( $\mathrm{Lu}$ ) and Ytterbium $(\mathrm{Yb})$ - Relative to the source rock, $\mathrm{Lu}$ is enriched in the weathered rock except in specimen 8I2 (Figure 26) $\mathrm{Yb}$ is concentrated in the lower third of the profile, but its abundance is considerably lower in the upper two-thirds.

Chromium ( $\mathrm{Cr}$ ) and Thorium (Th) - In most cases chromium and thorium are enriched relative to the parent rock. Thorium is depleted in specimen 880 .

Cobalt (Co) - Cobalt is very erratic. Its concentration ratio values vary from 0.23 to 6.86 .

TRACE ELEMENTS IN GIBBSITE AND LIMONITE

Trace element abundances were determined in a gibbsite nodule (S-891A) and several iron-rich pisolites (S-888A) and concentration ratios were computed to demonstrate the relative mobility of each trace element.

From the mineralogical examination, the pisolites consist mainly of limonite and the nodules are composed of gibbsite.

Trace elements highly depleted in the gibbsite nodules are Sc, $\mathrm{Hf}, \mathrm{Cr}, \mathrm{Co}, \mathrm{La}, \mathrm{Sm}, \mathrm{Lu}, \mathrm{Yb}$ (interpolated) and only thorium is enriched. In the pisolites, $\mathrm{Na}, \mathrm{Sc}, \mathrm{Hf}, \mathrm{Co}$, and $\mathrm{La}$ are depleted $\mathrm{Lu}, \mathrm{Yb}, \mathrm{Th}$, and $\mathrm{Cr}$ are enhanced. Assuming that a trace element associated with a mineral 
woula be enriched implies that thorium is the only studied element associated with gibbsite; whereas, $\mathrm{Lu}, \mathrm{Yb}, \mathrm{Th}$, and Co are associated with limonite.

\section{THE RELATIVE MOBILITY OF ELEMENTS IN \\ THE MOST WEATHERED ZONES FROM \\ EACH PROFIIE}

The relative mobility of the studied elements in the most weathered zones are summarized in Table VII. The composition of these specimens consists primarily of a mixture of clay and bauxite minerals (S-207 and S-812) or bauxite and iron minerals (S-891). Components that are always enriched in these profiles include $\mathrm{Fe}_{2} \mathrm{O}_{3}, \mathrm{Al}_{2} \mathrm{O}_{3}, \mathrm{TiO}_{2}$, $\mathrm{Sc}, \mathrm{Hf}, \mathrm{Cr}$, and Th; those which are depleted include $\mathrm{Na}, \mathrm{SiO}_{2}, \mathrm{Sm}$, La, and Yb. Flements that are either enriched or depleted include Lu and Co.

\section{RARE EARTH RATIOS}

Ratios of certain trace elements have been successfully used to aid in the correlation of basalt flows (Nathan and Fruchter, 1974). Could trace element ratios be employed to correlate parent rock with lateritic soils? In order to answer this question, rare earth ratios of $\mathrm{La} / \mathrm{Sm}, \mathrm{Sm} / \mathrm{Lu}$, and $\mathrm{La} / \mathrm{Lu}$ were determined from a suite of samples from the previously discussed profiles. Table VIII lists the results.

The La/Sm ratios remain about the same in the basaltic corestone profile, but in profile A and profile B they are generally lower. Ratios of $\mathrm{Sm} / \mathrm{Lu}$ and $\mathrm{La} / \mathrm{Lu}$ are erratic, but are generally lower than the parent rock. It is the opinion of this writer that these ratios would 
TABLE VII

ELEMEENTS ENRICHED OR DEPLETED IN THE MOST

WEATHERED ZONE FROM EACH PROFILE

SẢMPIE

PROFILE

NUMBER

ENRICHMENT

DEPLETION

- Corestone

207

A

891

$\therefore$

$B$

812

$\mathrm{Fe}_{2} \mathrm{O}_{3}, \mathrm{Al}_{2} \mathrm{O}_{3}, \mathrm{TiO}_{2}$,

$\mathrm{Sc}, \mathrm{Hf}, \mathrm{Cr}, \mathrm{Th}$, and

Co.

$\mathrm{Fe}_{2} \mathrm{O}_{3}, \mathrm{Al}_{2} \mathrm{O}_{3}, \mathrm{TiO}_{2}$,

$\mathrm{Sc}$, Hf, Cr, Th, and

$\mathrm{Na}, \mathrm{SiO}_{2}, \mathrm{Sm}, \mathrm{Co}$, and

Iu.

$\mathrm{Fe}_{2} \mathrm{O}_{3}, \mathrm{Al}_{2} \mathrm{O}_{3}, \mathrm{TiO}_{2}$,
$\mathrm{Sc}, \mathrm{Hf}, \mathrm{Cr}$, and Th.

$\mathrm{Na}, \mathrm{SiO}_{2}, \mathrm{Sm}$, La, Co, $\mathrm{Lu}$, and $\mathrm{Yo}_{\mathrm{o}}$ (estimated).

$\mathrm{Na}, \mathrm{SiO}_{2}, \mathrm{Sm}, \mathrm{La}, \mathrm{Lu}$; and $\mathrm{Yb}$.

$\mathrm{Yb}$ (estrmated).

Note: Concentration ratios are not determined for $\mathrm{Yb}$ in Profile $\mathrm{A}$ and $\mathrm{B}$, but $\mathrm{Yb}$ appears to be depleted in specimens 812 and 891 . 
TABLE VIII

RARE EARTH RATIOS

BASALT S-200B

$\underline{S-200 \mathrm{~A}} \quad \underline{S-200 \mathrm{C}}$

S-201

$\mathrm{S}-202$

$\mathrm{s}-203$

$\underline{S-204}$

$\underline{S-205}$

S-206

S-207

$\mathrm{La} / \mathrm{Sm}$

$\mathrm{Sm} / \mathrm{Lu}$

3.06

3.41

3.49

3.05

3.13

3.16

- 2.42

2.02

11.4

33.4

$\begin{array}{ll}11.58 & 16.87\end{array}$

23.2

19.7
$-\quad 47.7$

13.71

BASALT

(RLJ-2-7I)

S-954A

S-954

$\mathbf{s}-899$

S-897

$\underline{S-895}$

$\underline{\mathbf{S}-893 \quad \mathbf{S}-891}$

5.47

13.11

3.2

7.64

2.15

6.31

3.13

8.08

2.72

3.12

4.96

$\mathrm{Sm} / \mathrm{Iu}$

71.8

29.0

$\begin{array}{ll}16.13 & 13.6\end{array}$

25.8

3.09

$7: 40$

2.07

8.45

23.9

10.03

BASALT

(RLJ-2-71)

$\mathrm{La} / \mathrm{Sm}$
$\mathrm{Sm} / \mathrm{Lu}$

5.47

13.11

71.8

S-880

S-870

S-824

S-822

S-815

S-812

2.26

3.02

3.17

8.50

4.7

4.52

5.28

2.98

3.32

8.63

8.46

10.35

28.7 
not be key indicators for correlative purposes, because of dissimilarities between parent rock and laterite ratios. 


\section{SUMMARY AND CONCLUSIONS}

Mineralogical conclusions from this investigation are:

(1) A modal analysis performed on a suite of weathered specimens from a basaltic corestone shows that iron-rich glass is the first original constituent in the basalt to decompose, and followed by plagioclase and pyroxene, in that order (Figure 14).

(2) Most primary opaques are unaltered. Their crystal. forms could be used as an indicator for determining the source rock of the laterite.

(3) All three profiles indicate that kaolinite and metahalloysite initially formed as pseudomorphs after plagioclase.

(4) Alteration minerals associated with iron-rich glass and pyroxene include mainly amorphous clay, nontronite, hematite, and limonite.

(5) The most prevalent alteration product in the ferruginous bauxite is amorphous clay as indicated by petrographic, $\mathrm{x}$-ray, and differential thermal analysis.

(6) In all cases a clay zone ranging from a few inchès to several tens of feet separates the unaltered basalt from a zone consisting of bauxite minerals and iron minerals and/or clay and bauxite minerals. A two stage process for the formation of bauxite in Oregon and Washington is indicated.

(7) The ferruginous bauxite is not totally derived from basalt. In profile A (Wahkiakum County, Washington), the upper layer of ferruginous bauxite ore zone consists of numerous Fe-rich pisolites. 
A petrographic examination reveals the presence of angular to subangular quartz grains embedded in the iron-rich pisolites and earthy matrix. The shape of the quartz grains suggests that they are detrital and not authigenic in origin. The occurrence of quartz grains in the pisolitic material implies that the parent material is not entirely basalt.

In profile B (Wahkiakum County, Washington) a. 30 foot $(9.1 \mathrm{~m}$ ) thick, highly weathered sedimentary layer is interbedded in the laterized basalt flows.

(8) The extreme depth of weathering is evident in profile B (Wahkiakum County, Washington). The laterite extends from 17.0 feet $(5.2 \mathrm{~m})$ below ground level to at least 165 feet $(50.3 \mathrm{~m})$ and may reach to 200 feet $(60.5 \mathrm{~m})$. Assuming an average basalt flow is 30 feet $(9.1 \mathrm{~m})$ thick, then five or six flows are laterized.

Geochemical conclusions from this investigation are based on the abundances of nine trace elements ( $\mathrm{Sc}, \mathrm{Hf}, \mathrm{Cr}, \mathrm{Co}, \mathrm{La}, \mathrm{Sm}, \mathrm{Yb}, \mathrm{Lu}$, and $\mathrm{Th}$ ) and five major elements $\left(\mathrm{Fe}_{2} \mathrm{O}_{3}, \mathrm{Al}_{2} \mathrm{O}_{3}, \mathrm{SiO}_{2}, \mathrm{TiO}_{2}\right.$, and $\left.\mathrm{Na}\right)$ which were determined by instrumental neutron activation and wet chemical analysis on a suite of samples in three ferruginous profiles. Concentration ratios were computed from these abundances using empirical methods described by Goldrich (1938) to show the relative mobility of each element.

(1) In general, the mobility of the elements in profile $A$ (Wahkiakum County, Washington) and profile B (Wahkiakum County, Washington) show similar trends when compared to the intensity of weathering. Components that are depleted progressively upon weathering are $\mathrm{SiO}_{2}, \mathrm{Na}, \mathrm{Ia}, \mathrm{Sm}$, and $\mathrm{Lu}$; and elements enriched include $\mathrm{Al}_{2} \mathrm{O}_{3}, \mathrm{Fe}_{2} \mathrm{O}_{3}$, 
$\mathrm{TiO}_{2}, \mathrm{Sc}, \mathrm{Cr}, \mathrm{Th}$, and Hf. Cobalt behaves erratically. Elemental variations within the profiles may possibly be attributed to variations in the chemistry of the basalt, variations in the intensity of weathering, and variations in the chemical behavior of the elements.

(2) The elements in the basaltic corestone profile (Columbia County, Oregon) display similar mobility trends as the other profiles with the exception of $\mathrm{Sm}, \mathrm{La}, \mathrm{Lu}$, and $\mathrm{Yo}$. The behavior of these elements is unpredictable.

(3) Sm and La are associated with each other in the weathered rock as indicated from the mobility patterns.

(4) Elements enriched in all weathered samples are $\mathrm{Fe}_{2} \mathrm{O}_{3}, \mathrm{Al}_{2} \mathrm{O}_{3}$, and $\mathrm{TiO}_{2} \cdot$ Those depleted are $\mathrm{Na}$ and $\mathrm{SiO}_{2}$.

(5) In all specimens of decomposed rock $\mathrm{La} / \mathrm{Sm}, \mathrm{Sm} / \mathrm{Lu}, \mathrm{La} / \mathrm{Lu}$ ratios range from 2.15 to $7.64 ; 2.07$ to 23.2 ; and 8.45 to 73.4 , respectively. There seems to be no predictable relationship between these ratios in weathered and parent rock.

(6) Samples from the most weathered zone from each profile are enriched in $\mathrm{Fe}_{2} \mathrm{O}_{3}, \mathrm{TiO}_{2}, \mathrm{Al}_{2} \mathrm{O}_{3}, \mathrm{Sc}, \mathrm{Hf}, \mathrm{Cr}$, and Th relative to the basalt; and $\mathrm{Na}, \mathrm{SiO}_{2}, \mathrm{Sm}$, and La are depleted. Co and Lu are erratic.

(7) Trace elements associated in iron-rich pisolites are Lu, $\mathrm{Yb}$, Th, and Co. Only Th is associated with gibbsite. 
Allen, Victor T., '1948, Formation of bauxite from basaltic rocks of Oregon: Econ. Geol., v. 43, n. 8, p. 619-625.

Beeson, Marvin H., 1969, A trace element study of silicic volcanic rocks (Ph.D. dissert.): San Diego, University of California, $130 \mathrm{p}$.

Butler, J. R., 1953, The geochemistry of rock weathering (1): The Lizard area, Cornwall: Geochem. et. Cosmochim. Acta, v. 4, p. $157-178$.

'Carroll, Dorothy, 1970, Clay minerals: A guide to their x-ray identification: Geol. Soc. Am. Special Paper 126, 80 p:

Corcoran, R. E., and Libbey, F.W., 1956, Ferruginous bauxite deposits in the Salem Hills, Marion County, Oregon: Oregon Dept. Geol. and Min. Ind. BuIl. 46, $53 \mathrm{p}$.

Deer, W. A., Howie, R. A., and Zussman, J., 1966, An introduction to the rock forming minerals: New York, John Wiley and Sons, Inc., 528 p.

Dennen, W. H., and Anderson, P. J., 1962, Chemical changes in incipient rock weatherjng: Geol. Soc. Am. Bull., v. 73, p. 375-384.

Dicken, Samuel N., 1965, Oregon geography: Ann Arbor, Michigan, Edwards Brothers, Inc., $147 \mathrm{p}$.

Frarklin, Jerry F., and Dryness, C. T., 1969, Vegetation of Oregon and Washington: U.S.D.A. Forest Service Research Paper PNW-80, 216 p.

Goldrich, S. S., 1938, A study of rock weathering: Jour. Geol., v. 46, p. $17-58$.

Gordon, Glen E., Randle, Keith, Goles, Gordon G., Corliss, John B., Beeson, Marvin H., and Oxley, Susanna S., 1968, Instrumental activation analysis of standard rocks with high-resolution $\gamma$-ray detectors: Geochem. et Cosmochim. Acta, v. 32, p. 369-396.

Gordon, Mackenzie, Jr., and Murata, J. J., 1952, Minor elements in Arkansas bauxite: Econ. Geol., v. 47, n. 2, p. 169-179.

Grim, Ralph E., and Rowland, Richard A., 1942, Differential thermal analysis of clay minerals and other hydrous materials: Illinois Geol. Survey Inv. 85, p. 746-818. 
Grim, Ralph E., 1968, Clay mineralogy: New York, McGraw-Hill Book Company, $596 \mathrm{p}$.

Hìgs, Nelson B., 1971, personal communications.

Hook, John W., 1971, personal communications.

Huntting, Marshall T., Bennett, W. A. G., Livingston, Vaughn E., Jr., and Moen, Wayne S., 1961, Geologic map of Washington: Washington Div. of Mines and Geology.

Jackson, Ronald L., 1971, Description of the ferruginous bauxite ore profile in Columbia County, Oregon: The Ore Bin, v. 33, n. 12, p. 223-229.

Kerr, Paul F., 1959, Optical mineralogy: New York, McGraw-Hill Book Company, $441 \mathrm{p}$.

Libbey, F. W., Lowry, W. D., and Mason, R. S., 1945, Ferruginous bauxite deposits in northwestern Oregon: Oregon Dept. Geol. and Min. Ind. BuIl. 29, $97 \mathrm{p}$.

1946, Ferruginous bauxite deposits in northwestern Oregon: Econ. Geol., v. 41, n. 3, p. 246-265.

Lowry, W. D., and Baldwin, E. M., 1952, Late Cenozoic geology of the lower Columbia River Valley, Oregon and Washington: Geol. Soc. Amer. Bull., v. 63, n. 1, p. 1-24.

Livingston, Vaughn E., Jr., 1966, Geology and mineral resources of the Kelso-Cathlamet area, Cowlitz and Wahkiakum Counties, Washington: Washington Div. Mines and Geology Bull. 52, 110 p.

Mason, Brian, 1966, Principles of geochemistry: New York, John Wiley and Sons, Inc.

Nathan, Simon, and Fruchter, Jonathan S., 1974, Geochemical and paleomagnetic stratigraphy of the Picture Gorge and Yakima basalts (Columbia River Group) in Central Oregon: Geol. Soc. Am. Bull., v. 85, p. 67-76.

Peck, D. L., 1961, Geologic map of Oregon west of the 12lst meridan: Oregon Dept. Geol. and Min. Ind.

Pettijohn, F. J., 1957, Sedimentary rocks, New York, Harper \& Row, $718 \mathrm{p}$.

Polynov, B. B., 1937, Cycle of weathering: Murby, Iondon. 
Reiche, Parry, 1943, Graphic representation of chemical weathering: Jour. Sediment. Petrol., v. 13, n. 2, p. 58-68.

1950, A survey of weathering processes and products: Alburquerque, New Mexico, The University of New Mexico Press, n. 3, 95 p.

Short, Nicholas M., 1961, Geochemical variations in four residual soils: Jour. Geol., v. 69, p. 534-571.

Smith, Joseph V. (ed.), 1964, Index (inorganic) to the powder diffraction file 1964: A:S.T.M. Special Tecn. Pub. 48-N2, 786 p.

Smyth, C. H., Jr., 1913, The relative solubilities of the chemical constituents of rocks: Jcur. Geol., v. 21, p. 105-120.

Speil, Sidney, Berkelhamer, Louis H., Pask, Joseph A., and Davies, Ben., 1945, Differential thermal analysis, its application to clays and other aluminous minerals: U. S. Bureau of Mines Tech. Paper 664, $81 \mathrm{p}$.

Taylor, S. R., 1966, The application of trace element data to problems in petrology, in Physics, and chemistry of the earth: n. 6, p. 133213.

Tiller, K. G., 1958, The geochemistry of basaltic materials and associated soils of southeastern Scuth Australia: Jour. Soil Sci., v. 9, n. 2, p. 225-241.

Tobi, A. C., 1963, Plagioclase determination with aid of the extinction angles in sections normal to (010). A critical comparison of current albite-carlsbad charts: Am. Jour. Sci., v. 261, p. 157167.

Wells, N., 1960, Total elements in top soils from igenous rocks: an extension of geochemistry: Jour. Soil Sci., v. ll, n. 2, p. 409-424.

Warren, W. C., Norbisrath, Hans, and Grivetti, R. M., 1945, Geology of northwestern Oregon west of Willamette River and north of latitude 45 15': U. S. Geol. Survey Oil and Gas Inv. (Prelim.) Map 42.

Wilkinson, W. D., Lowry, W. D., and Baldwin, E. M., 1946, Geology of the St. Helens quadrangle, Oregon: Oxegon Dept. Geol. and Min. Ind. Bull. 31, 39 p. 